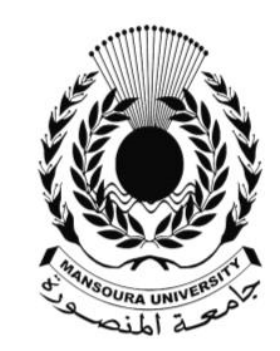

جامعة المنصـورة الماندة

$$
\text { كليـة الآداب }
$$

\title{
قصر المشور الزيانى بمدينة تلمسان دراسة آثارية هعمارية
}

\author{
إعـــ/د \\ دكتور / محمد السيد محمل أبو رحاب \\ أستاذ الآثار والعمارة الإسلامية المساعد \\ قسم الآثار - كلية الآداب - جامعة أسيوط
}

مجـلة كلــية الآداب - جامعـة المنصــورة

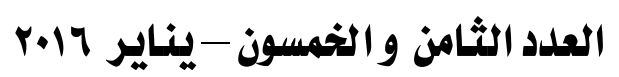




\section{قصر المشور الزيانى بـمدينة تلمساز دراسة آثارية معمارية}

\section{د/ محمد السيد محمد أبور رحاب}

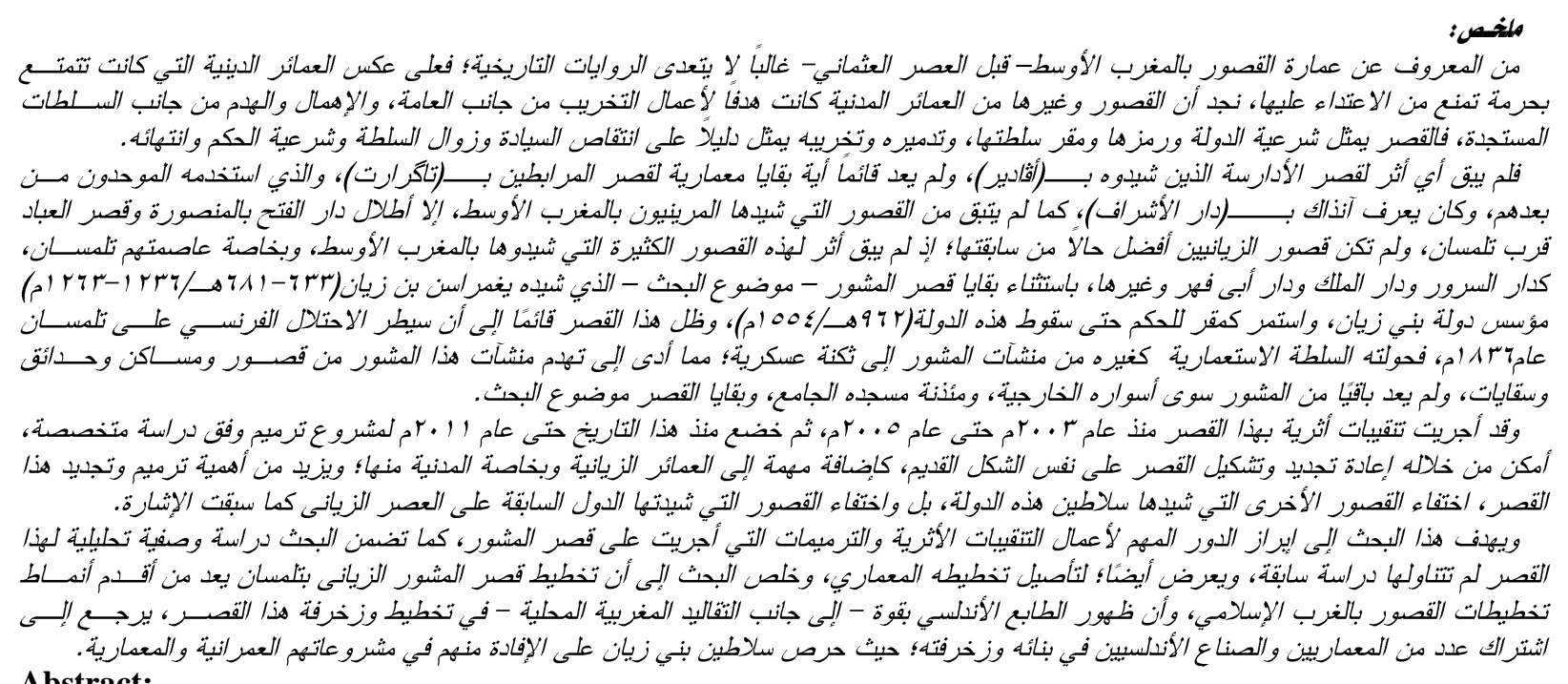
Abstract:

What is known about the architecture of palaces in Middle Maghreb before the Ottoman Age is often no more than historical anecdotes. Unlike religious buildings which enjoyed a sanctity that prevented attacking them, we find that palaces and other civil buildings were a target for vandalism by the public and neglect and destruction by new authorities. The palace represented the legitimacy, symbol and power seat of the State.

There are no remains of the Idrisid Palace which they built in Agadir, and there are no architectural remains of their royal palace. Its destruction is an evidence of the diminution of sovereignty and the demise of their power and the legitimacy of their reign. At that time it was known as Dar Al-Ashraf. All that remained of the palaces built by the Marinids are the ruins of Dar Al-Fath in Mansoura and Al-Obad Palace near Tlemcen. The Zayyanid palaces were no better than their predecessors, as there are no remains of these numerous palaces which they built in Middle Maghreb, specially in Tlemcen, their capital city, such as Dar Al-Serour, Dar Al-Malik, Dar Abi Fahr and others, except for the remains of Al-Mashour Palace, the subject matter of this research, which was built by Yaghmurasen Ibn Zyan (633-681 H. / 1236-1263 A.D.), the founder of the Zayyanid dynasty. It continued as a seat of government till the fall of this State (962-1554 A.D.). This palace remained till the French occupied Tlemcen in 1836, and the colonial authority changed it, like other buildings of Al-Mashour, to a military barracks, which led to the destruction of the buildings of this Mashour, including palaces, lodgings, gardens and waterings. All that remained of AlMashour were only its outer walls, the minaret of its mosque and the remains of the palace under study.

Archaeological excavations were carried out in this palace during the period from 2003 to 2005, and from that date to 2011 it was subject to a repair project based on specialized studies, through which the palace was renovated and restored to its old shape as an important addition to the Zayyanid architecture, specially civil architecture. What makes the repair and renovation of this palace more important is the disappearance of the other palaces built by the sultans of this dynasty, and even the disappearance of the palaces built by the dynasties preceding the Zayyanid Age, as we have previously mentioned.

This research aims at highlighting the important role of the archaeological excavations and repairs of Al-Mashour Palace. The research also included a descriptive and analytical study of this palace, something which no previous study has addressed. It also establishes the origin of its architectural layout. The research concluded that the layout of Al-Mashour Palace in Tlemcen is considered one of the oldest layouts of palaces in Islamic Maghreb, and that the appearance of Al-Andalusian character in the layout and decoration of this palaces, besides local Moroccan traditions, can be attributed to the participation of a number of Andalusian architects and craftsmen in building and decorating it, as Zayyanid sultans were keen on benefiting by them in their constructional and architectural projects.

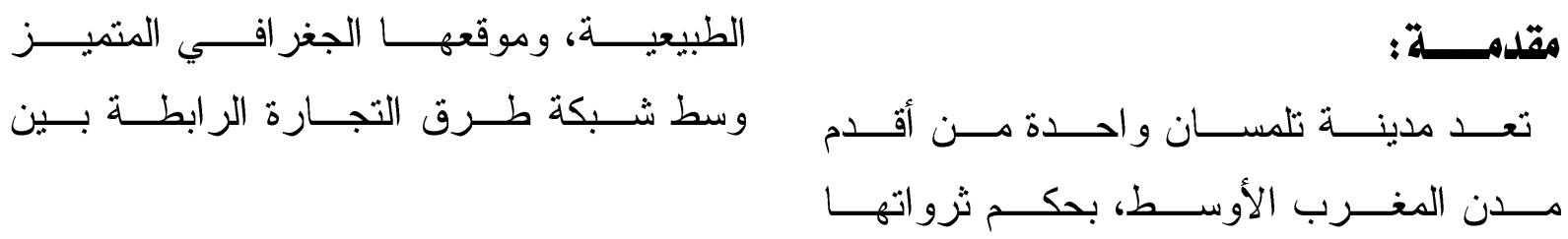




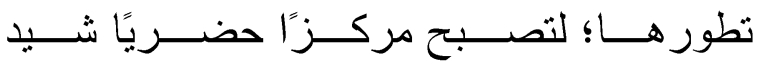

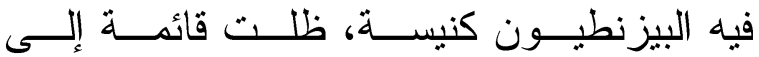
وقت متأخر من العصر الإسلامي("). في حين نسب ابن خلــدون تأســيس تلمسيــان لأمر اء بني يفرن الزناتيين، وذكر أنه لم يقف:"

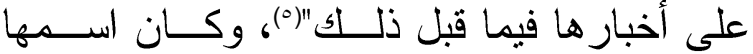
(أقادير) أو (أجادير) (Agâdir) بربرية؛ بمعنى الصخرة أو هضبة ذات انحسـدار وعر، وتتطبق هذه التسمية على موقع تلمســان التي شيدت على هضبة تشرف على سهل مـن هن

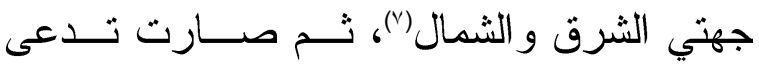

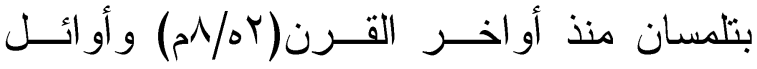

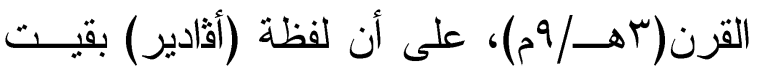

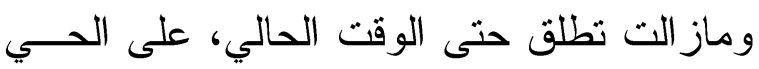

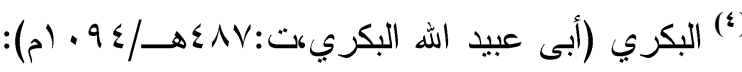
المسالك والممالك، تحقيق أدريان فان ليوفن و أندرى

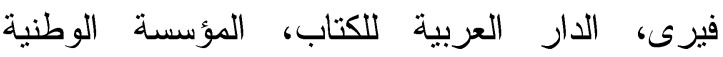

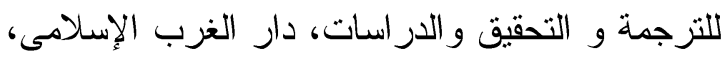

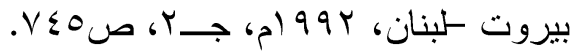

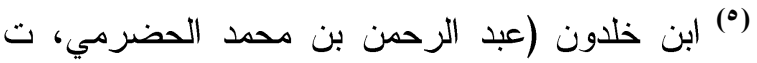

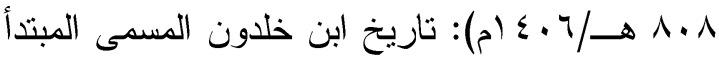
و الخبر في تاريخ العرب و البربر ومن عاصرهم من آنان ذوي الثأن الأكبر، تحقيق: خليل شحادة، دار الفكر

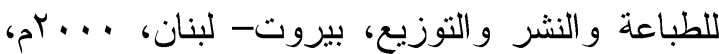

$$
\text { ج }
$$

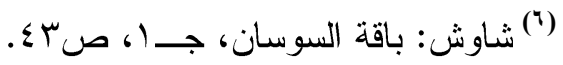

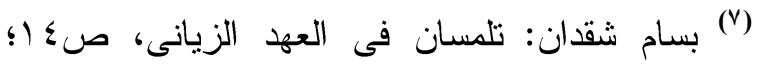

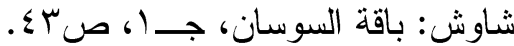

الثــــمال و الجنــــوب و الثــــرق و الغـــرب(')،

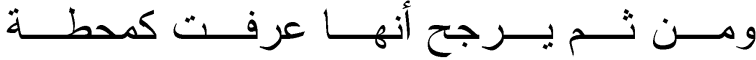

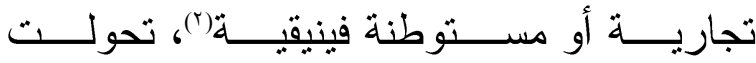

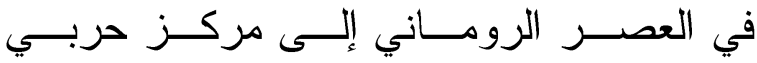

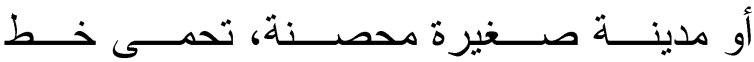
الليمس فـي غـرب بــلاد المغــرب، ســيت الميت

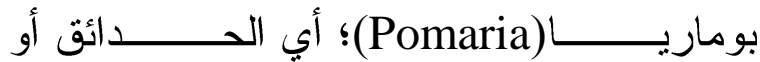
البســاتين، تقــع إلــى الثــرق مــن تلمســـان

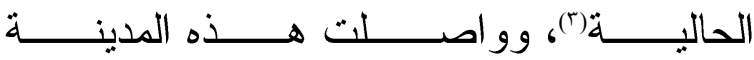
(') العبد العزيز لعرج: مجموعة المنشآت المعمارية

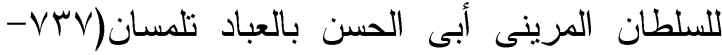

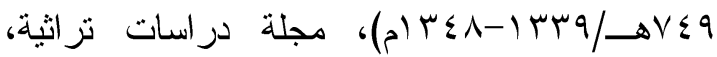
مخبر البناء الحضاري للمغرب الأوسط- معهد الآثار،

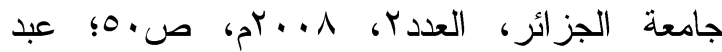

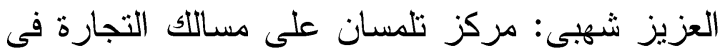
العصر الإسلامى الوسيط، كتاب مؤنمر تلمسان الإسلامية بين التزاث العمرانى و المعمارى و الميراث

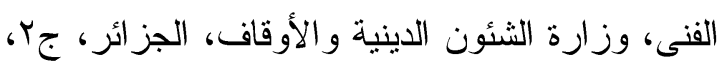
(1)

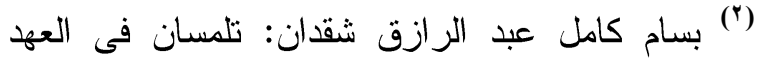

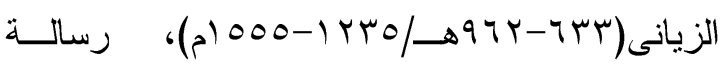

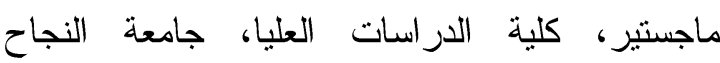

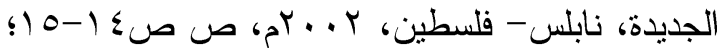
دليلة مطماطى بن زرقة: الزليج على العمائر الدينية

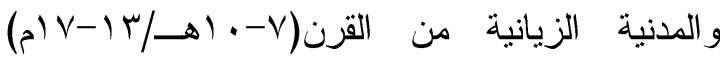

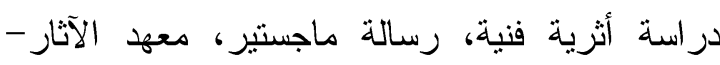

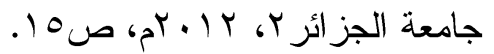

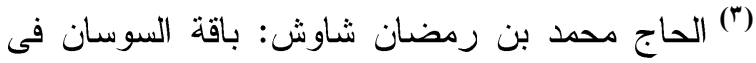
التعريف بحاضرة تلمسان عاصمة دولة بنى زيان،

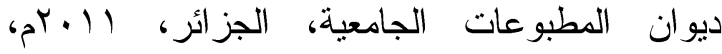
جـا، صو؛؛؛ دليلة مطماطى: الزليج على العمائر الدينية و المدنية الزيانية، صها 


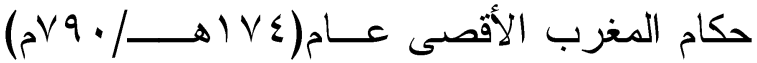
دون حرب و لا قتال، فشيد بها إدريـسـ الأكبــر

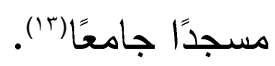

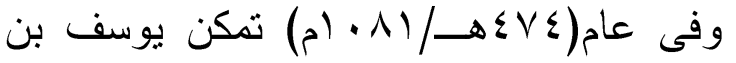
تاشفين من إخضاع تلمسان لسلطة المــر ابطين، وشيد بها مدينة جديدة بــالقرب مــن (أجــادير)

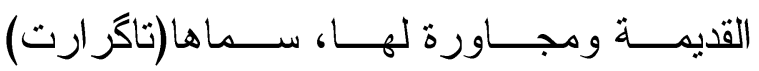
أو (تــاجر ارت) (Tagrart)، ومعناهـــــا باللغــــة البربرية المحلة أو المعسكر، و أحاط المــدينتين

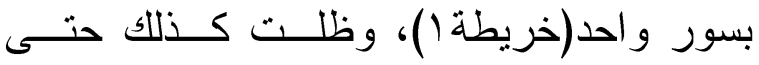

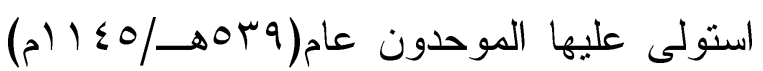
(؛)"، فقامو ا بتخريبها وقتل سكانها، ثم عدلوا عن سياستهم هذه، فأعادو ا تعمير ها وتجديد وتــرميم تحصيناتها وأسوارها، حتى صارت:"من أعــز

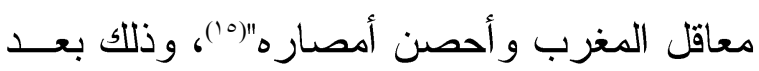
ظهور خطر بني غانية الطامعين فـي الســلطة

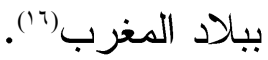

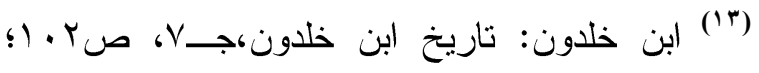

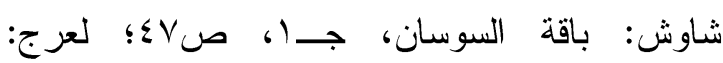

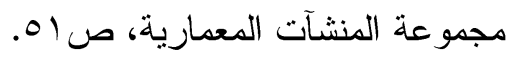

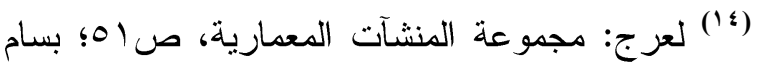

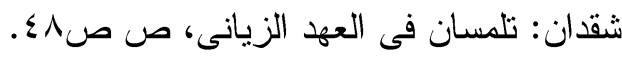

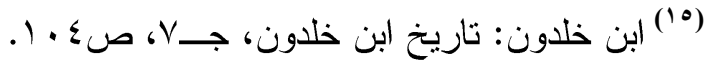

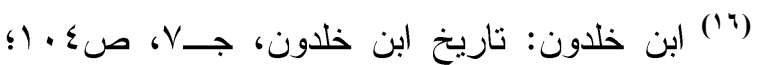
سيدي محمد نقادي: وظائف أسوار مدينة نلمسان العتيقة، مجلة در اسات تزاثية، مخبر البناء الحضاري وطياء

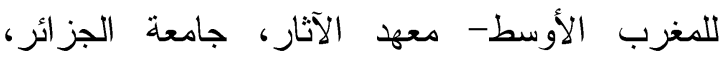

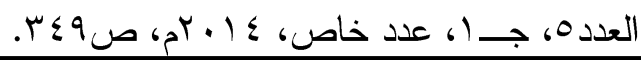

الذي كانت به المدينة القديمة بالجهة الشرقية من تلمسان الحالية (^)(خريطة (1).

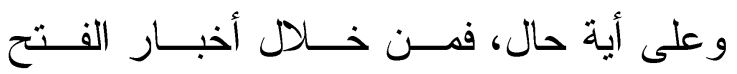
الإسـامي لبلاد المغرب برزت أهمية تلمسان منذ

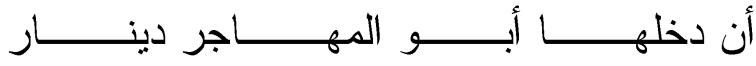

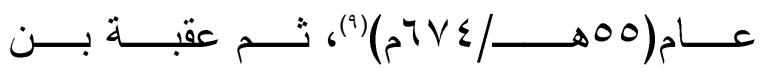

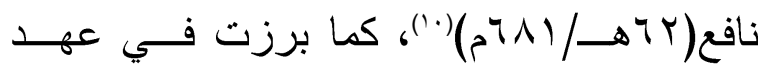
حسان بن النعمان عندما اتخذها كقاعدة للمنطقة المحيطة بها، ومركز لإقلــيم غـرب المغــرب الأوسط'"')، وفى عهد موسى بن نصــير الـذـي

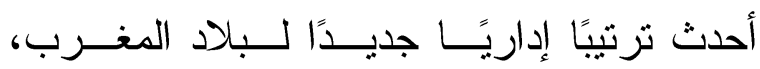
أصبحت تلمسان مركزًا لو لاية المغرب الأوسط، وإحدى مر اكز ضرب العملة الإسلامية في بلاد

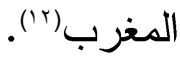
وفى النصف الأول مــن القــرن(بهـــ/مدم)

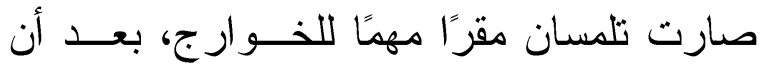
خضعت لحكم أمر اء محليين من قبيلة بني يفرن

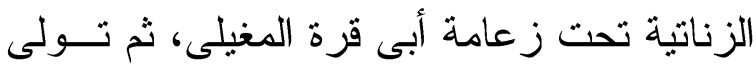
بعده بنو خزر المغراويون الزنــاتيون، ومـــنهم محمد بن خزر المغراوى الذي سلمها للأدارســة

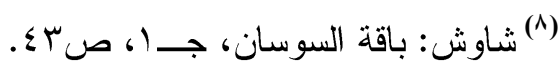

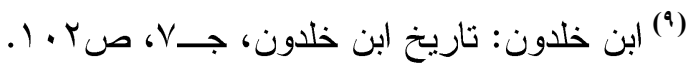

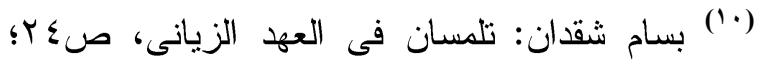
لطيفة بور ابه: نماذج من الزخرفة الهندسية فى عمارة جامعى أبى مدين و الحلوى بتلمسان، كتاب تلمسان الإسلامية بين التزاث العمرانى و المعمارى و الميراث

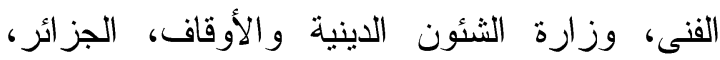

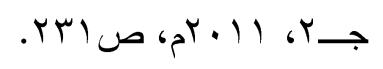

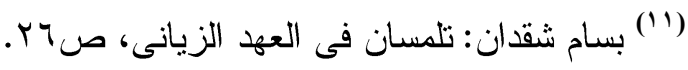

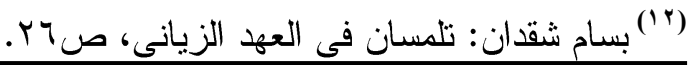


ولم يكتف ســلاطين هـــهـ الدولــة بالصـــاع المحليين في مشاريعهم العمر انية و المعماريسـة،

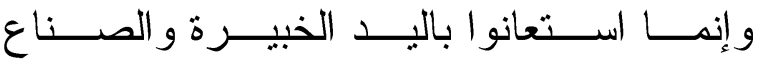
المتخصصين في مختلف شـئون البنــاء مسـن الأندلس، وبخاصة في عهر كل من السلطان أبو

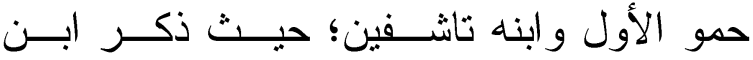

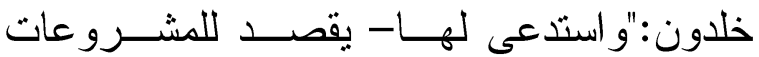
العمر انية و المعمارية- الصــناع و الفعلــة مــنـن الأندلس لحضارتها وبداوة دولتهم يومئذ بتلمسان، فبعث إليهما السلطان أبو الوليد صاحب الأندلس

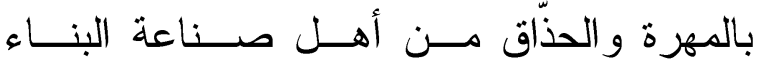
بالأندلس، فاستجادو الهــم القصــور و المنــــازل

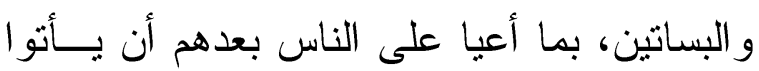

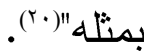

وكان لتزايد الكثافة السكانية التــي شـــتها تلمسان في العصر الزيانى، ولا سيما أنها مثلت محطة استقرار مهمة لمهاجرى الأندلس، تــأثير"

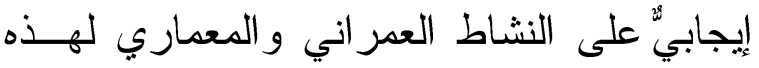

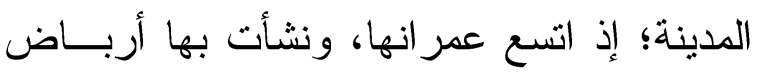

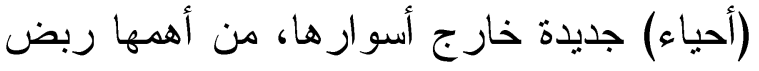
العُبّاد أو سيدي أبى مدين بالجنوب الشرقي لهذه المدينة، وربض سيدي الحلــوى إلــى الثـــــال

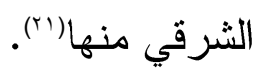

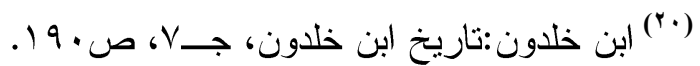

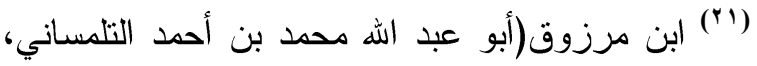

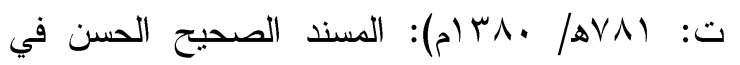
مآثر ومحاسن مولانا أبي الحسن، دراسة وتحقيق: د.

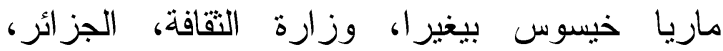

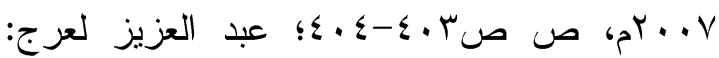

\section{التطــور العمرانسيـ الملينــة تلمســان في العصـر}

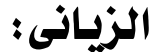

شهدت هدينـــة تلمســان ازدهـــارًا اقتصـــاديًا و عمر انيًا وسياسيًا غير مسبوق في عصر دولـــة بني عبد الواد أو بني زيان، وذلك منذ أن اتخذها يغمر سن بن زيان مؤسس هذه الدولة عاصــمة

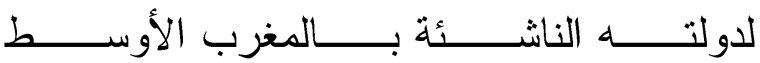

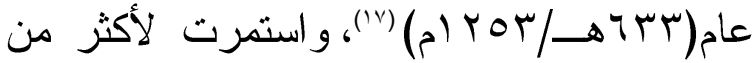

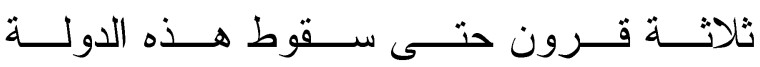

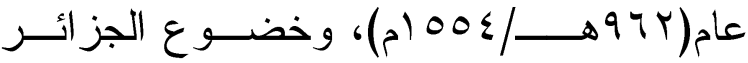

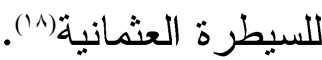
إذ اهتم حكام هذه الدولة بتشييد وتجديد مختلف

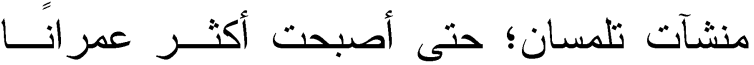

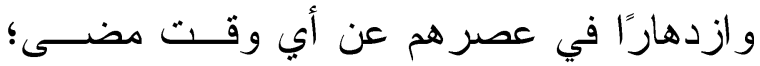
حيث:"اختطو ا بها القصور المؤنقــة و المنـــازل الحافلة، و اغترسو الرياض و البساتين، و أجــروا خلالها المياه، فأصبحت أعظم أمصار المغرب،

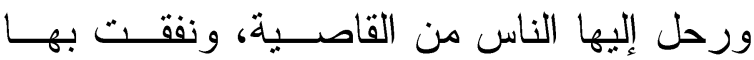
أسواق العلوم و الصنائع، فنشأ بها العلماء و اشتهر فيها الأعلام، وضاهت أمصار الدول الإســلامية و القو اعد الخلافية"(19).

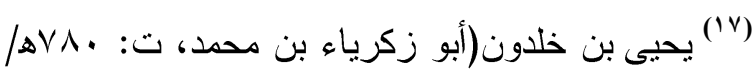

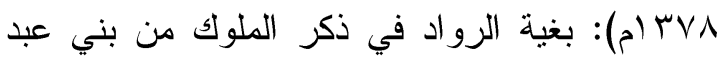

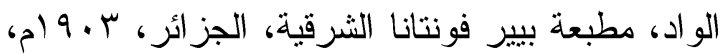

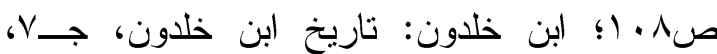
صع .

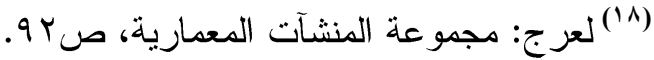

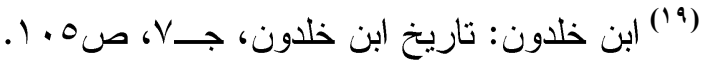


لتجسيد سيطرتهم عليها؛ إذ شيد السـلطان أبــو

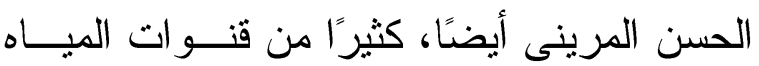

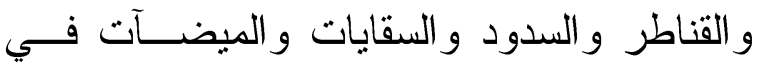

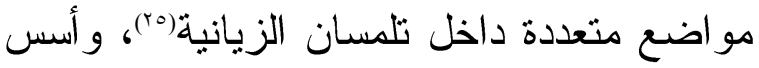

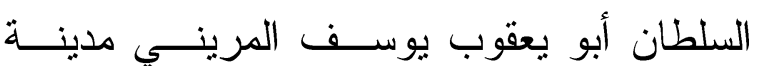

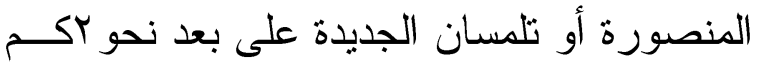
من تلمسان الزيانية، و التي خربها الزيانيون، فقام أبو الحسن بتجديدها و إحباء معالمها بعد استيلائه

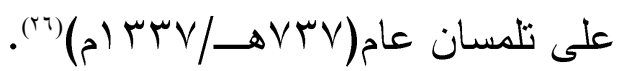
وتعد المنصورة المدينة الثالثة التـي تتشـــل

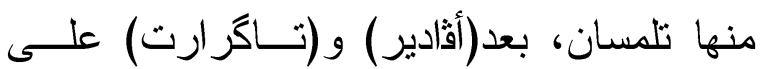
التو الي (vV)؛ مما يشير إلى أن الصراع السياسـي و العسكري الطويل بين الـــرينيين و الزيــانيين كانت لله- رغم نتائجه السلبية- نتائج إيجابية في ولين لئن مجال العمران و العمارة؛ حيث حظي المغـرب لئه الأوسط، وبخاصة عاصمته تلمسان بنصيب و افر من النشاط العمر اني و المعماري لسلاطين بنـي لإي مرين (r) (ب)

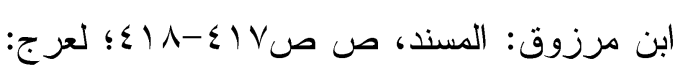

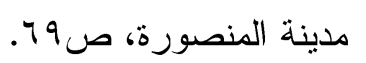

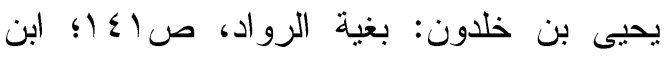
(ए)

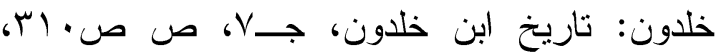
( )

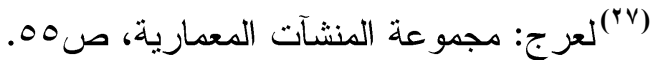
(†^) محمد أبو رحاب: ملامح تخطيط العمائر الدينية المرينية بالمغرب الأقصى ومدينة تلمسان بالمغرب الماني الأوسط - دراسة آثارية مقارنة، كتاب مؤتمر تلمسان الإنسلامية بين التزاث العمراني و المعماري والميراث الفني، منشورات وزارة الثؤون الدينية والأوقاف، والفيرات

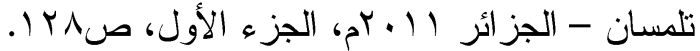

ومن ثم يمكن القول، إن من بين أسباب تثييد السلطان أبو الحسن المرينى- بعد استيلائه على بلى

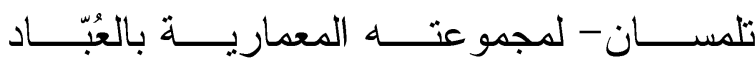

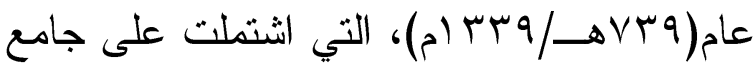
ومدرسة وحمام وقصر (rr)، وكذللك تثـيبيد ابنــهـ السلطان أبي عنان لهجموعته المعمارية بربض وفل سيدي الحلوى التي تضم جامعاً ومدرسة وزاوية وضريحاً وميضأة(r)، يعود إلى ازدحام عــــران

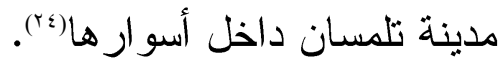

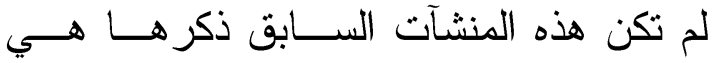
الوحيدة التي شيدها سلاطين بني مرين بتلمسان؛ مدينة المنصورة المرينية بتلمسان - دراسة تاريخية أثرية في عمر انها وعمارتها وفنونها، مكتبة زهراء

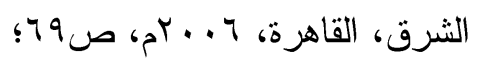

Marçais, W., et G., Les Monuments Arabes de Tlemcen, Paris, 1903, p.240; Bourouiba, R., L'Art Religieux Musulman en Algérie, S. N. E. D., Algeri, 1983, p.252.

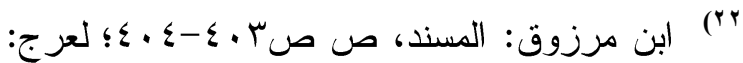

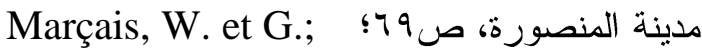
Les Monuments Arabes de Tlemcen, p.240; Bourouiba, L'Art Religieux Musulman, p.252. ابن الحاج النميري(أبو القاسم برهان الدين بن

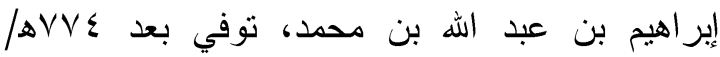

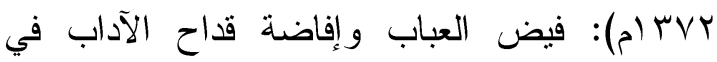
الحركة السعيدة إلى قسنطينة و الز اب، دراسة ونشر د.

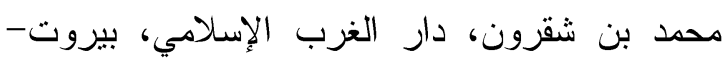

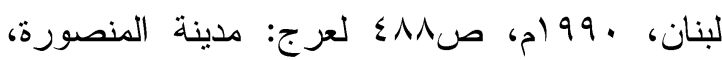

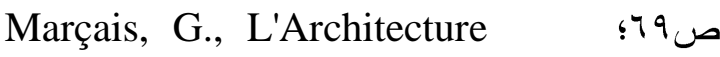
Musulmane d"occident Tunisie, Algérie, Maroc, Espagne et Sicile, Paris, 1954,p.298.

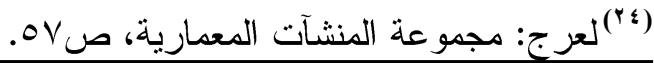


يتقام القصر الملكي يحصنه ويفصله عن موضع

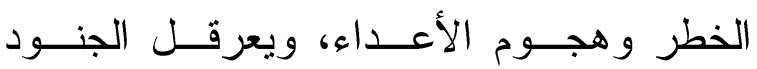
المهاجمين قبل وصولهم إليه، وهى فكرة روعيت في اختيار موضع جل القصاب بالمدن الأندلسية

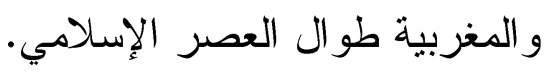
وزيادة في تحصين مقر السلطة المتمثل فـي لفي

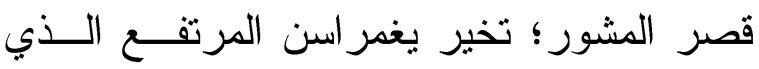

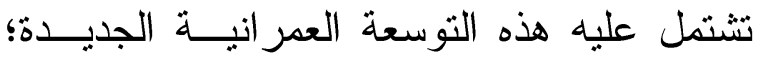

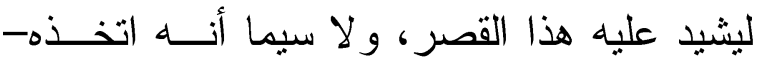
وكل حكام بني زيان من بعده- مقـررًا رســـيًا

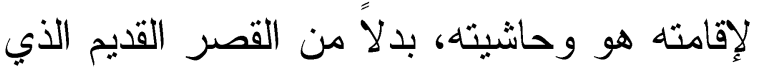

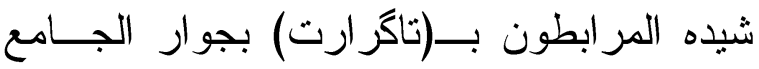
الكبير ، و استخدمه الموحدون من بعدهم(هrr)، وكان

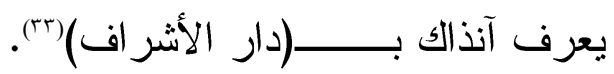

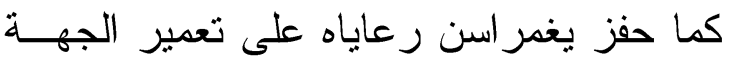
الشرقية المجاورة لهذا المشور، وخصص منطقة باب الجياد للمهاجرين الأندلسيين الر اغبين فـئي الاستقرار بتلمسان، وترتب على هذه التوسعات

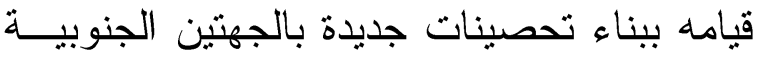
و الغربية لتلمسان، وبناء (باب التويتة) بالجهــة لهينة

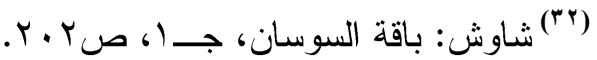
ها (بَ)

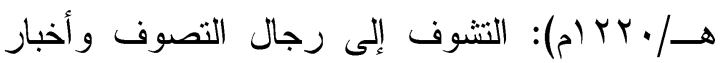

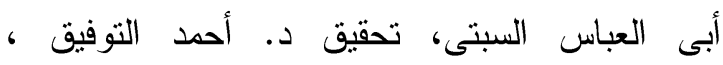

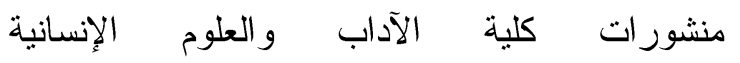

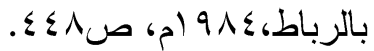

على أية حال، يلاحظ أن عمران تلمسان امتذ في عهذ يغمراسن - أول حكام بني عبد الواد في اتجاه الجنوب و الجنوب الثرقي(خريطةب)، و هو الامتداد الطبيعي لاتســاع عهـران هــــه المدينة، التي تشرف أسوارها في الجهة الثمالية على منحدر يزيد ميله إلى أكثر من ·r\% عـن

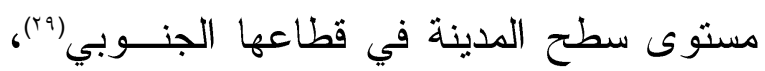

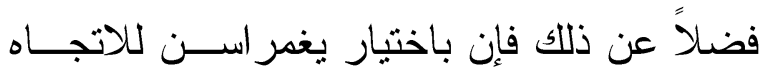
الجنوبي الثرقي لهذه التوسعات العمر انية، يكون

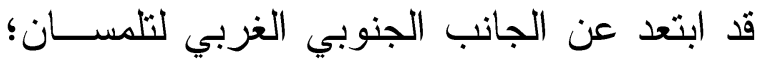
ذللك الاتجاه الذي كان يمثل موضع الخطر الذي يتم دائمًا اقتحام المدينة من خلاله، سواء من قبل الته

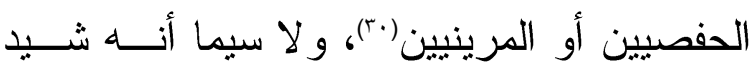

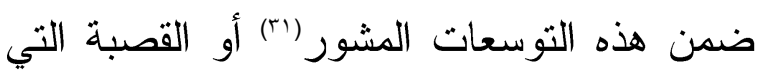
اشتملت على قصــره المعـروف بـــــــــر

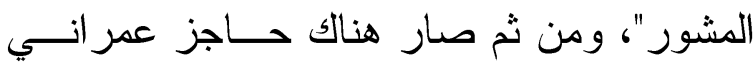
صبدي محمد نقادي: وظائف أسوار مدينة تلمسان، ص. ص. (1) (") سيدي محمد نقادى: وظائف أسوار مدينة تلمسان، ص. ص. (") المشور في الاصطلاح المغربي المكان الذب يعقد فبه الحاكم أو السلطان اجتماعاته مع وزرائه وكتابه وقواده، لمناقثة شئون الدولة و التثاور في أمور الرعية وقت السلم والحرب، والمشور الزيانى بنلمسان عبارة عن قلعة محصنة محاطة بسور مرتفع، كان النقان يشتنل، فضلاً عن القصر الملكي، على عدة قصور

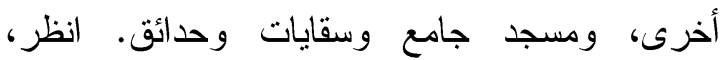

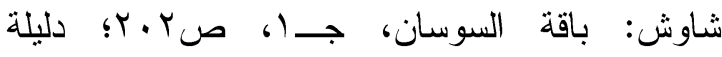
مطماطى: الزليج على العمائر الدينية و والدنية

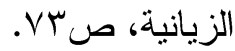




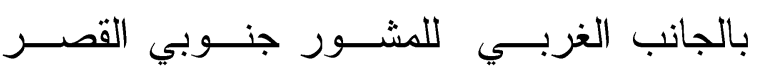

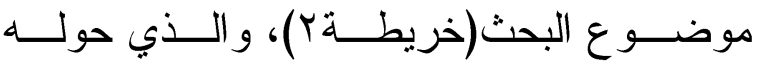
الاحتلال الفرنسي إلى كنيسة ثم إلى مستثــفى، ولم يتبق من عمارته الزيانية إلا المئننة(19).

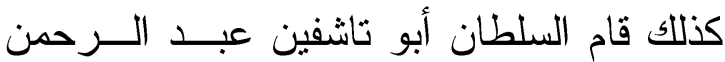

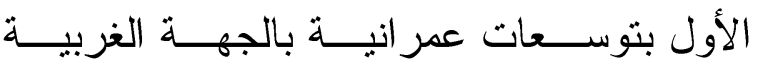
لتلمسان(خريطة)؛؛ حيث شيد الصهريج الكبيــر

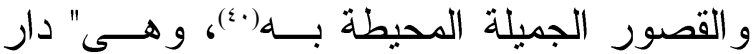
الملك" و "دار السرور" و "دار أبى فهر "((')، وقـــــ

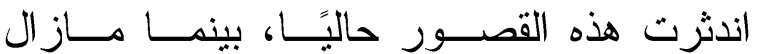
الصهريج الكبير قائمًا غربي الددينة بالقرب من باب كثوطة(خريطةب)، لكنه جاف بدون مساء،

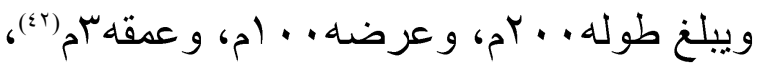
كما شيد هذا السلطان المدرسة التاشفينية(1) 年

(99") شاوش: باقة السوسان، جـا، صع V؛ رشيد

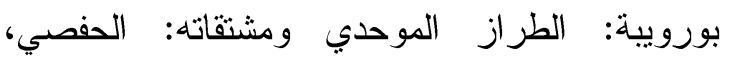
الدريني، الزياني، و النصري، بحث نشر في كتاب العناب الفن العربي الإسلامي، الجزء الثئ الثاني- العمارة، المنظمة العربية للتربية والثقافة والعلوم، تونس،

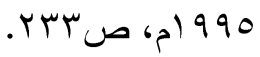

(•) سيدى محمد نقادى: وظائف أسوار مدينة تلمسان،

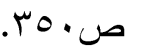

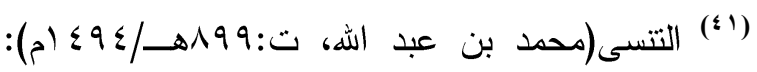
مقتطف من نظم الدرر والعقيان في بيان شرف بني

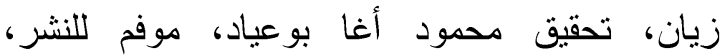

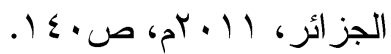
ل
الجنوبية، وتشييد (باب فاس) بالجهــة الجنوبيــة

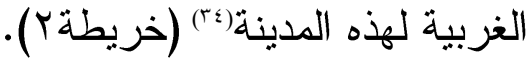
وبعد الحصـار الطويـلـ لتلمســـان مــن قبــلـ السلطان أبي يعقوب يوســ المرينــ، الـــي

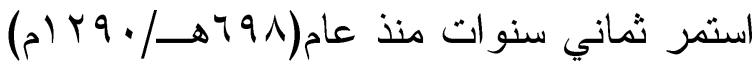

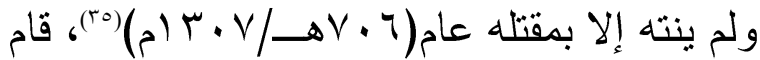
السلطان أبو حمو موسى الأول حفيد يغمراسـن بتعمير القطاع الغربي من تلمسان؛ حيث حسي

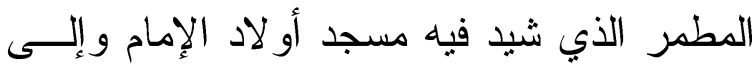
الغرب منه مدرسة أو لاد الإمــام أول مدرســـة الهـا

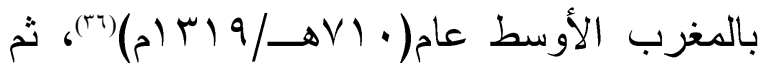
شيد حي القصبة الذي خصصد لاستقرار رهائنه

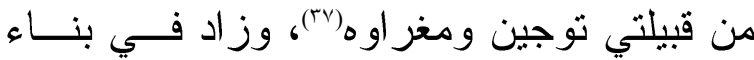

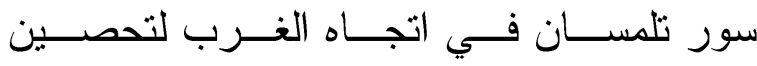

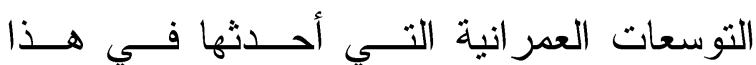
الاتجاه(هA)، كما شيد مسجدًا جامعًا (جامع المشور)

ص. صن. ميدى محد نقادى: وظائف أسوار مدينة تلمسان،

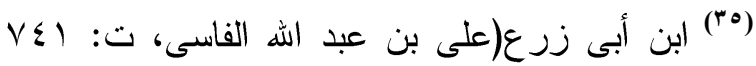

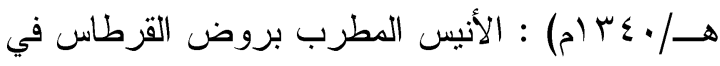

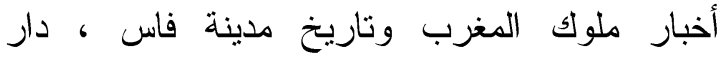

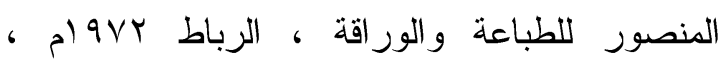

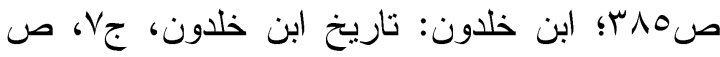
("י) سيدى محد نقادى: وظائف أسوار مدينة تلمسان،

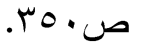
سيدى محمد نقادى: وظائف أسوار مدينة تلمسان، ص. ص. سيدى محمد نقادى: وظائف أسوار مدينة تلمسان،

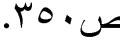


ابن خلدون (v)، وتشييده لجامع وضريح ســيدي

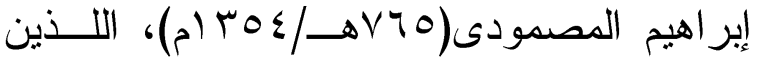
ماز الا قائمين حتى الآن (^)(خريطة ب)، و المدرسة البعقوبية التي كانت تجاور هذا الجامع المذكور،

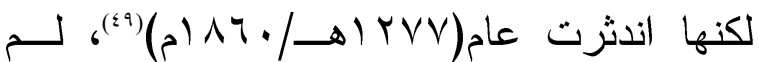
يشيد سلاطين بني زيان بعـــ هــذا السـلطان المذكور منشــآت معماريـــة بــارزة بتلمســان كأسلافهم؛ إذ غلب على فترات حكمهم الحروب و الصر اعات الخارجية مع جير انهم ومنافــــهر من بني مرين وبني حفص، وفى الفتن الداخليــة للمنافسة على العرش، وقمع العصـاة من القبائـلـل التى كانت تثور عليهم بإيعاز مــن المــرينيين و الحفصيين وبمساعدتهم المادية و المعنوية فــي كثير من الأحيان(.).

\section{المشور الزيانى ومكوناته المعمارية( خريطةت ) :}

يقع المشــور بالقطــاع الجنــوبي الثــرقي

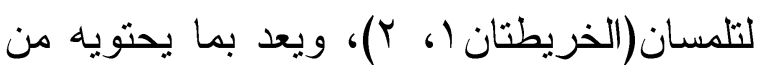

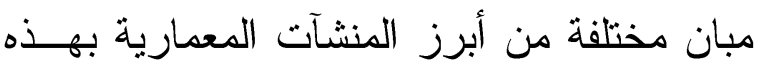

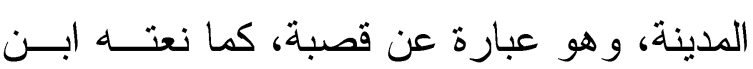
خلدون (10)، أو قلعة محصنة محاطة بأسو ار يزيد

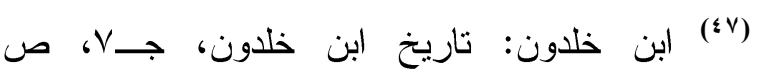
ص.

Marçais, W. et G.; Les Monuments (ఓ^) Arabes de Tlemcen,pp.170-171; Bourouba, L'Art Religieux Musulman,p171.

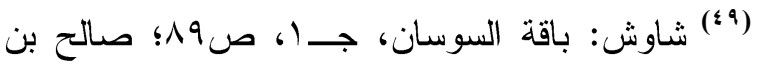

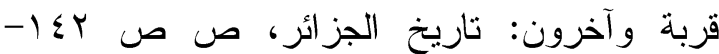

6 ) 0 r

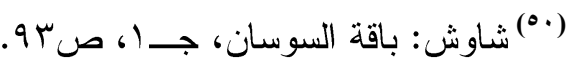

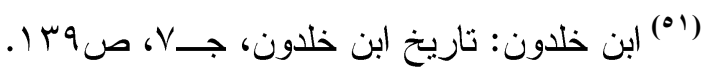

المر ابطى(ب)(خريطة r)، التي هدمتها ســلطة

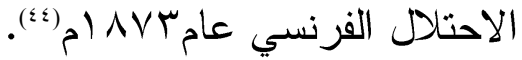
كما قام السلطان أبو تاشــفين أيضًّــا، بتعميــر القطاع الجنوبي لتلمســان؛ لاســتيعاب الكثافــة

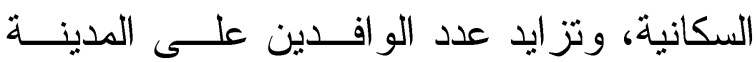

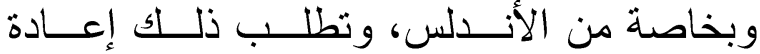
تحصين هذه المدينة من جهتي الجنوب و الغرب، وفتح باب كشوطة بالقطاع الجنوبي الغربي من السور، وقد بلغت تلمسان في عهد هذا السلطان

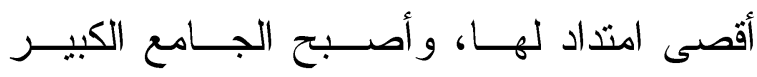
المرابطى يتوسط مركز المدينة (ن) (خريطــة ب)، وصارت تضاهى أهم عو اصم الغرب الإسلامي كفاس وتونس و غرناطة(1). وبمقتل هذا السلطان أبى تاشفين الأول على يد

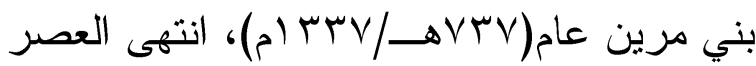
الذهبي لدولة بني عبد الو اد بتلمسان، فباستثناء ما

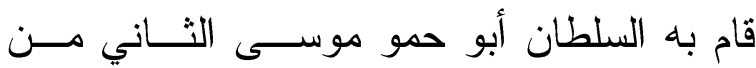
استرداد لتلمسان من بني مرين، ثم تجديد وترميم

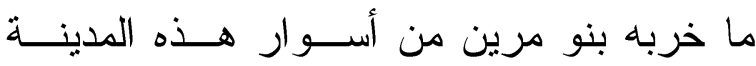

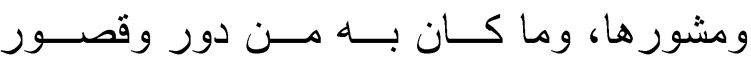
ومتنز هات:" لا يعبّر عن حسنها" على حد قــول

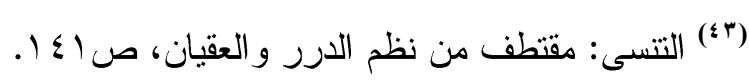

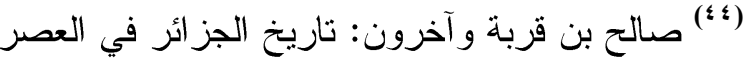

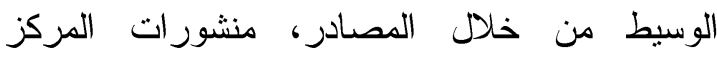

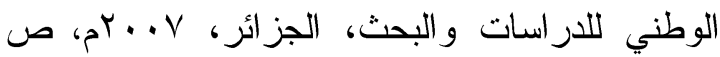
ص (॰) سيدي محمد نقادي: وظائف أسوار مدينة تلمسان،

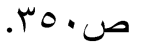

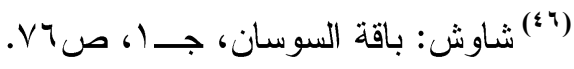


على السلطان من جهة أخرى(107)، وكان ذلك وفقا لإفادة ابن خلدون:"من أغرب مـــا حكـي فــي العصور من سجن" من صيخ تأمين السلطة في المدن الإسلامية. ولم يقتصر الإبداع في المشور الزياني علـى التصميم المعماري لقصوره وتكويناته المعمارية، بل امتد إلى احتواء هذه القصــور علـى آلات

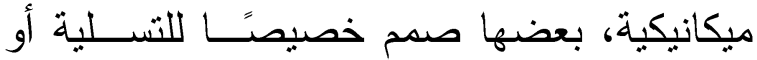
المتعة الجمالية، من ذلك شجرة من الفضة تغرد على أغصـانها جميــع أنـــواع الطيــور، أمـــر

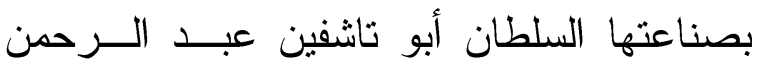

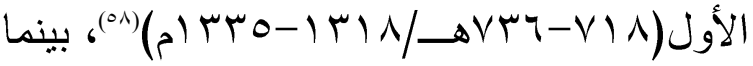
كان البعض الآخر من هذه الآلات يخدم أغر اضًا عملية كالساعة الدقاقة أو المنجانة، التي صنعها

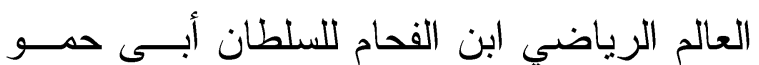

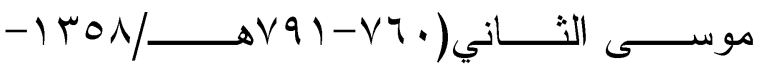

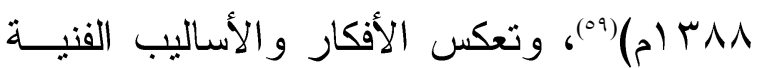
التي كانت تتضمنها هذه الآلات، كما وصــفتها الروايات التاريخية المعاصــرة، تقــدم علــوم الهندسة الميكانيكية، وتطور تقنية الآلات في ذلك

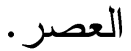

(07) شاوش: باقة السوسان، جـا، ص107.

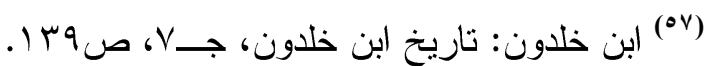

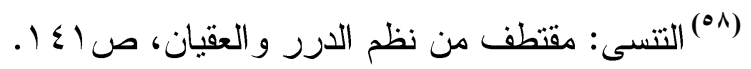

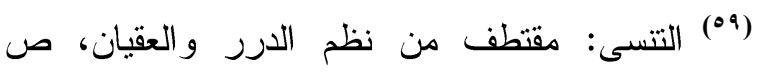

ارتفاعها عن • (م(اللوحات ا-1))، ويشغل مساحة

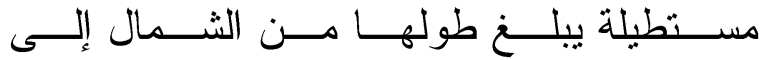

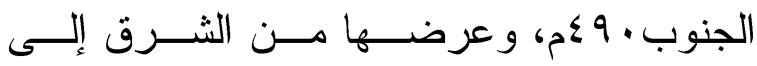

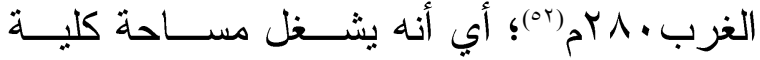

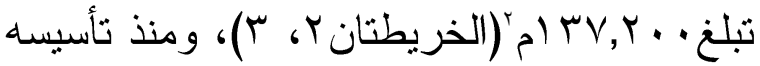

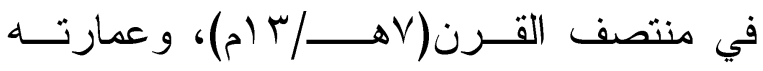
وتحصينه محــلـل اهتمـــام، و عنايـــة الســلطان

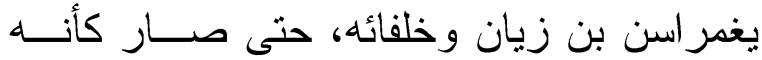
مدينة صغيرة مستقلة داخل تلمسان؛ لتعدد مر افقه من قصور ودور ومساجد وحمامــات وحــدائق ومخازن ومطامير؛ لتخزين الحبوب، و المــؤن المختلفة(")، و هى ظاهرة شو هدت في القصـــاب و القلاع الأندلسية و المغربية على السو اء(؛ُم. وكان المشور يضم فضلاً عن القصر الملكي، قصورًا أخرى أقل منه مساحة وزخرفة، محاطة بالحدائق و السقايات، خصصت لسكنى رؤســـاء القبائل كبني توجين ومغر اوة(00)، وكان ســـاهم بهذا المشور تشريفًا لهم من جهة، لكنهم كـانوا بمنزلة الرهائن إذا ما قبائلهم انشقت، وتمــردت (Or) دليلة مطماطى: الزليج على العمائر الدينية والمدنية

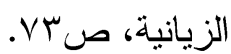

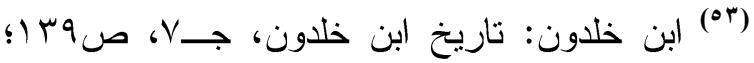

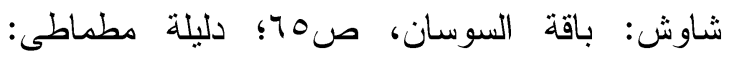

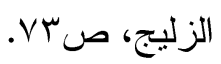

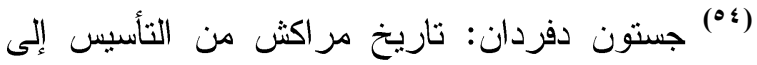

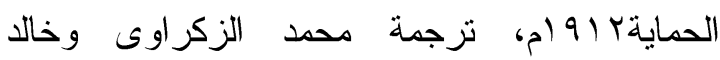
المعزوزى، منشورات وزارة الأوقاف و الثئون الإسلامية، المملكة المغربية، دار أبى رقراق للطباعة وردات

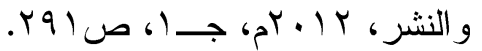

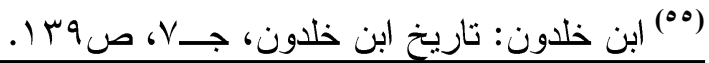


وتخريب الزيانيين لمدينة المنصـــورة المرينيــة قرب تلمسان تشفياً و انتقاماً، بعد أن فلك أبو ثابت عـــامر المرينـــي الحصــــار عـــن تلمســـان

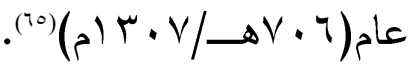
و على أية حال، تزتب علـى تعـدى سـلطة

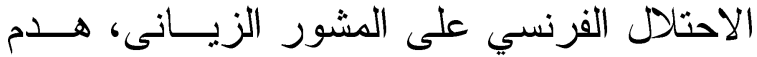
وتخريب منشآت هذا المشور من قصور ومساكن

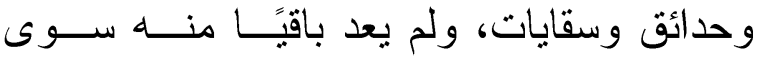

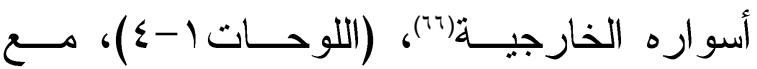

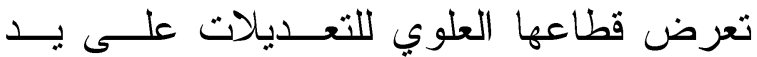
الفرنسيين(†V)؛ لتتو افق هذه الأسوار مع متطلبات الأسلحة النارية الحديثة، وكذلك بقي بابــا هــذا

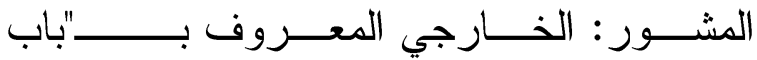
التويتة"(اللوحتان ه-7)، و الداخلي الذي يصل بين

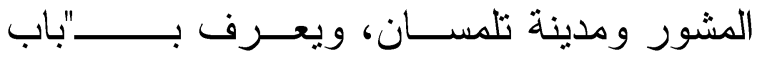
المشور"((1)، ومئذنة مسجده الجامع، وكذلك بقايا

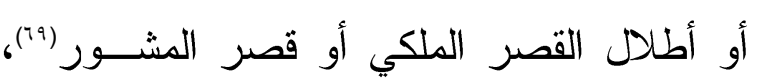
موضوع البحث (خريطةب). وقد أمكن من خلال بقايا قصر المشور، فضلاً عن التقبيات الأثرية التــي أجراهـــا المركـز

المنصور للطباعة و الور اقة، الرباط، سلو ام، ص

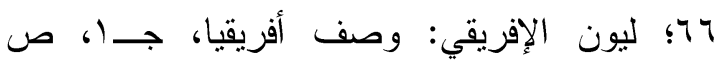

(10) ابن خلدون: تاريخ ابن خلدون، جـلا، ص .

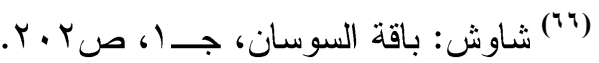

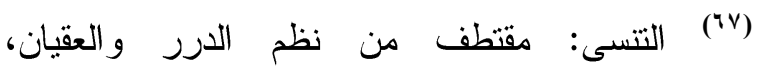

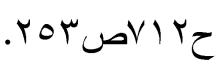
(^^)

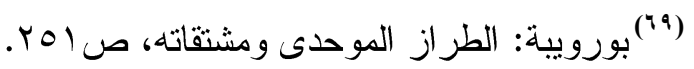

وقد تعرض هذا المشور للتخريب عدة مسـرات على يد بني مرين (")؛ بوصفه رمــزًا للســلطة

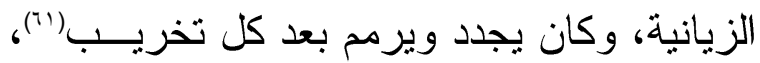
وظل هذا المشور قائمًا إلى أن سيطر الاحــتلال

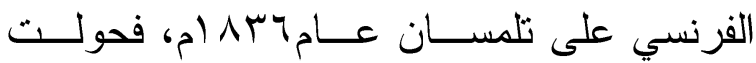
السلطة الاستعمارية المشور إلى ثكنة عسكرية، كما حولت جامعه إلى كنيسة ثم إلــى مستشـــى عسكري كما سبقت الإشارة:(r)؛ مما بشير إلـى سلبيات البعد السياسي على العمران والعمــارة، و هى ظاهرة مارستها كثير من الدول والسلطات المستجدة في العصور الوســطى، ســـواء فــي المغرب أو في المشرق، كتخريب الفـاطميينعلى سبيل المثال - لمدينة تيهرت عاصمة الدولة

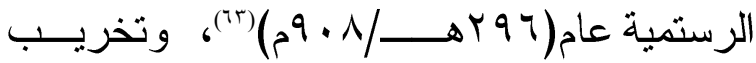

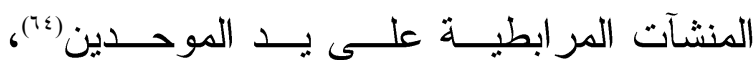

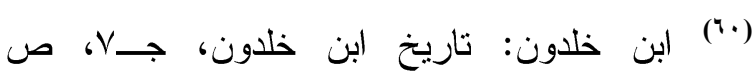
ص. ص. 1919 ("') دليلة مطماطى: الزليج على العمائر الدينية و المدنية

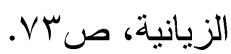
(rir) الرزقى شرقي: الجسور الأثرية بمدينة تلمسان

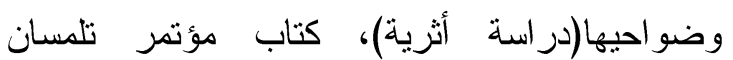
الإسلامية بين التراث العمراني و المعماري و الميراث

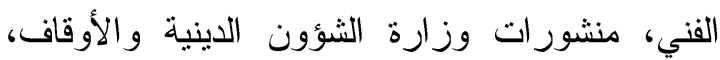

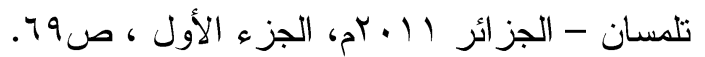

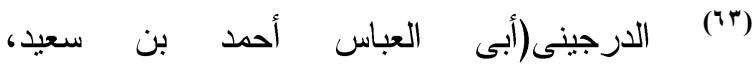

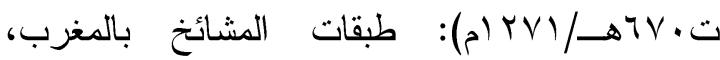
تحقيق إبراهيم طلاى، مطبعة البعث، قسنطينة -

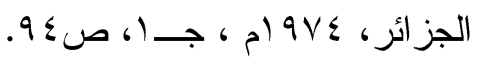

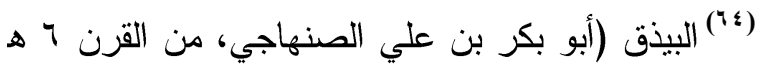

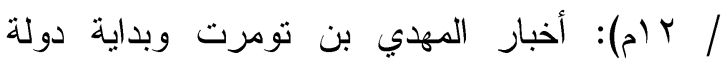

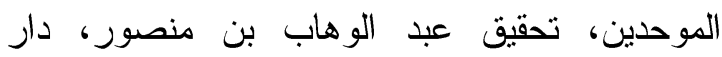


المعمارية لهذا القصر ، وما يزخرفها من تكسيات الزليج و الجص، وما يغطي بعض قاعاتها مــن أسقف خشبية، وما كشفته الحفائر السابق الإشارة إليها، على الوثائق الخاصة بهذا القصــر التـى جمعت من دولتي فرنسا و إسبانيا، إلــى جانــبـ استخدام مشروع الترميم لأساليب ومواد الإنشاء ذاتها التى كانت مستخدمة في بناء وزخرفة هذا القصر، مع تحديد تكســات الــزليج و الجــص الأصلية بإطار ات؛ تمييزًا لها عـن التكســيات الحديثة المستخدمة في استكمال تلك التكســيات

$$
\text { القديمة(اللوحات } 0 \text { 1-1 ( ). }
$$

ومن ثم أمكن إعادة تجديد وتشكيل القصر على الشكل القديم نفسـه، كإضـافة مهمة إلى العمــائر الزيانية، وبخاصة المدنية منها؛ ويزيد من أهمية

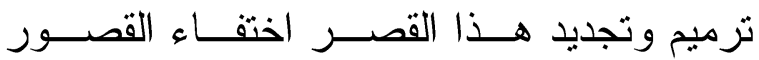
الأخرى التي شيدها سلاطين هذه الدولة، كــدار

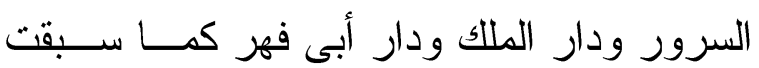
الإشارة، بل واختفاء القصور التى شيدتها الدول السابقة على العصر الزياني، ليس بتلمسان فقط،

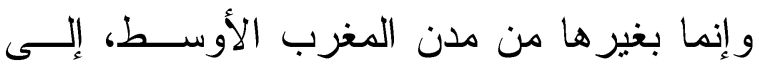
جانب عدم تو افر معلومات عن التخطبط والشكل المعماري لهذه القصور ، ولم يعد باقيًا من عمارة القصور بالمغرب الأوسط قبل العصر العثماني، باستثناء قصر المشور موضوع البحث، ســوى بـور أطلال دار الفتح بالمنصورة وقصر العباد قرب تلمسان، اللذين شيدهما سلاطين بني مرين أثناء سيطرتهم على المغرب الأوسط("Nr).

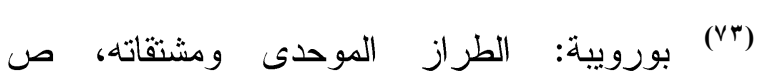

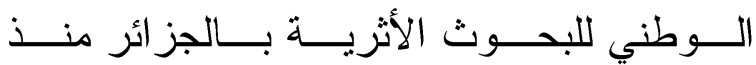
عامب . . rام بموضع القصر، تحديد مساحة هــذا القصر ووحداته وعناصره المعمارية، و الكشف عن قطاعات كبيرة من الزليج المتعدد الألــــوان، سواء المستخدم في كسوة الأجزاء السقلى مــن الجدران بارتفاع يصل إلى نحو •0, ام، أو فـي أهي تكســية أرضــبة قاعــات وحجــر ات القصــر و الممر ات و السلالم، وحوض المياه الكبير الــذي يتوسط صحن القصــر (*م)، وبقايــا التكســيات الجصية التي كانت تغطي الأجز اء العليــا مــن جدران هذا القصر ، وبعض بقايا الأسقف الخشبية التي كانت تغطي قاعاته(اللوحات V-ع ())، مــع الأخذ في الاعتبار أن هناك مر افـق وملحقــات خاصة بالقصر تقع خــار ج القطــــاع الجنــوبي

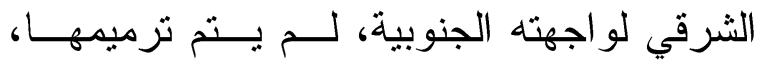
و إعادة هيكلتها حتى الآن (v'). ثم خضع قصر المشور منذ عامه . . بام، ولمدة خمس سنوات تقريبًا، إلى مشروع ترميم وفــق در اسة متخصصة (rr)، اعتمد فضلا عـنـ البقايــا

(v•) (ليلة مطماطى: الزليج على العمائز الدينية و المدنية الزيانية، صس V.

(V') دليلة مطماطى: الزليج علئ على العمائر الدينية و المدنية

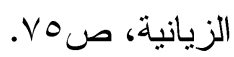

(Ar) أنشرف على إنجاز هذا المشروع مكتب الدراسات

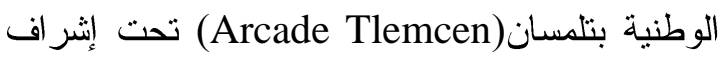
مهندس/شعلي عبد الصمد، الذي أتقدم له بالشكر و افرًا

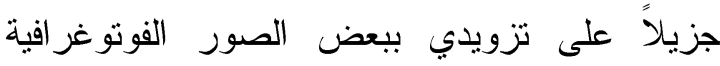
لقصر المشور قبل وأثناء إجراء الحفائر وأعمال التزميم، و المسقط الأفقي والأشكال التوضيحية للقصر و التي تنشر في هذا البحث لأول مرة. 


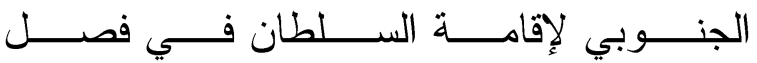
الشتاء (م) (شكل (D/).

\section{الوصف المعماري لقصر المشور:} ا-مداخل القصر:

يشتنمل هذا القصر حاليًا على ســتة مـــاخل؛ ثلاثة منها بو اجهته الغربية و الثلاثـــة الأخــرى بالو اجهة الجنوبية، يتوصل من مداخل الواجهــة الونة الغربية الثلاثة إلى جناح الحريم، ويلاحظ أن هذه

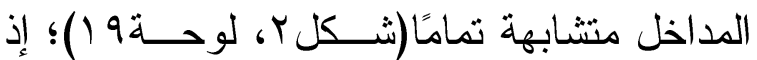
يبلغ اتساع كل منهابم وارتفاعها نحو عم، يتوج المدخل الأوسط عقد على هيئة حدوة فرس، بينما

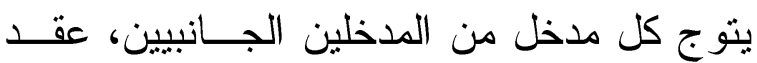

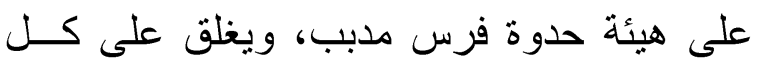

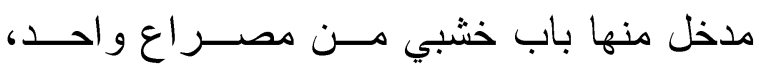
تتوسطه خوخة يغلق عليها مصر اع واحد مسن الخشب، كما يلاحظ أن المدخل الأوسط كانـــ تتقدمه فسقية دائرية الثكل، غير موجودة حاليًا لكن ماز الت آثار ها باقية حتـى الآن بأرضــية

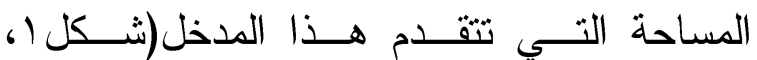

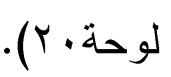

وأما مداخل الواجهة الجنوبية فمتشابهة فيهــــا

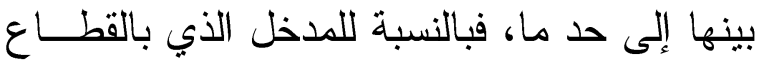

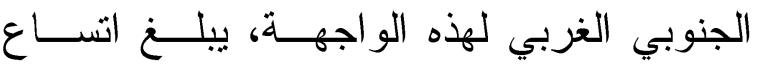

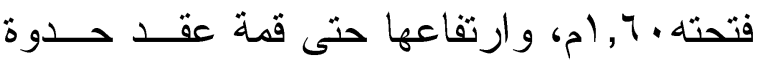
الفرس المدبب الذي يعلوها نحو آم، يغلق علىها

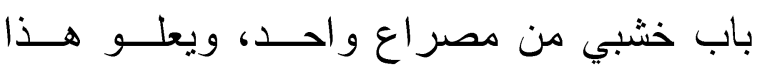

الزئة (vo)

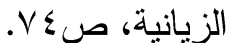

ومن هذا المنطلق تبرز أهمية هذا البحث الذي

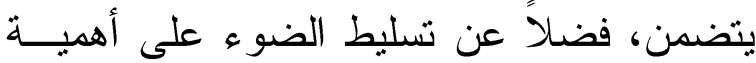
التتقيبات الأثرية و الترميمات التي أجريت علـى قصر المشور ، دراسة وصـفية تحليليــة لهـــال

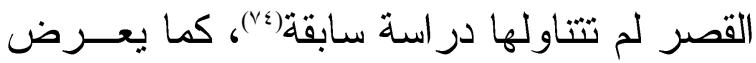
هذا البحث أيضًا؛ لتأصيل تخطيطه المعماري.

\section{التخطيط المعماري لقصر المشور( شكل ) )}

يشغل هذا القصر مساحة مسنطيلة الثكل، يبلغ

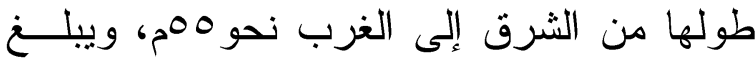

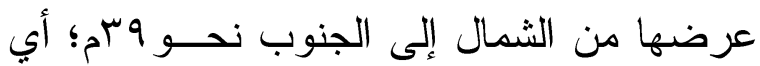

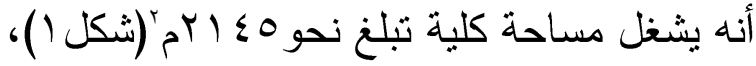

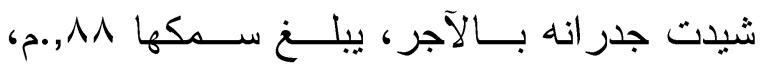
ويتكون تخطيط هذا القصر من أربعة أجندــة، يتقدمها رواق يفصلها عن الصــحن المكثــوف الذي يتوسط هذا القصر، يضم الجناح الثـــرقي

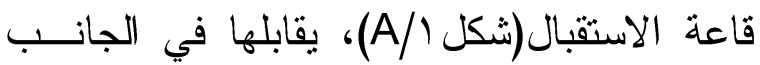

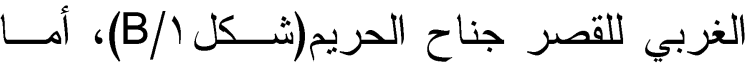

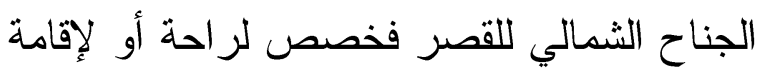

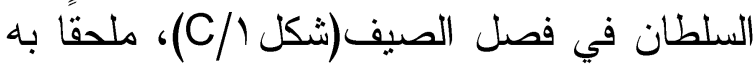
حمام القصر، بينما خصصت وحســات الجنــاح

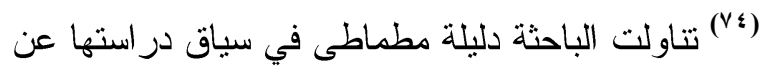

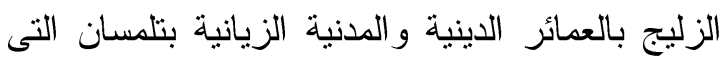

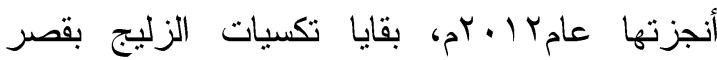

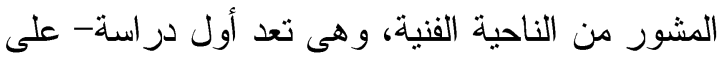
حد علمي- تتعرض لهذا القصر بعد إعادة تجديده

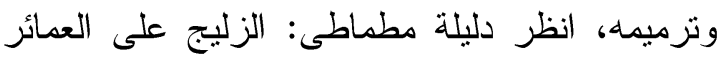

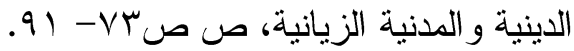


قائمة حتى الآن(لوحةYY)، و هو يشبه من حيث اتساعه وارتفاعه المدخل الثاني السابق وصــفه تمامًا، ويوصل كالمدخل الثاني السابق وصــفه إلى الرواق ذاته الذي يتقدم جناح الراحة الجنوبي وقاعة الاستقبال (شكل () . r - الصحن (لوحة r يتوسط القصر صحن مكشوف يشغل مســاحة مستطيلة الشكل، يبلغ طولها من الثــرق إلـى

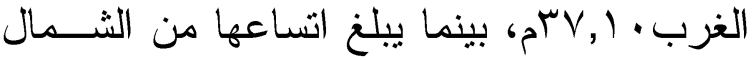
إلى الجنوب.9,V (م؛ أي أن مســاحته الكلبــة

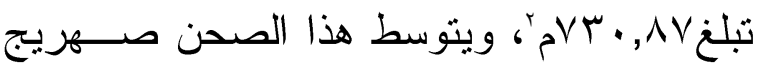
أو حوض مستطيل الشكل، يمتذ من الشرق إلى الغرب بطول الصحن، بينما يبلغ اتســاعه مــن

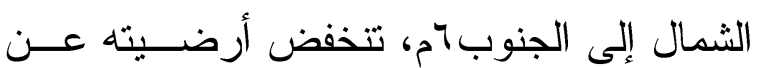
مستوى أرضية الصحن بمقدار ام، وقد فرشـــ

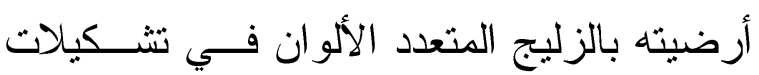
هندسية، ويتوسطه فسقية من الرخــام دائريـــة الشكل ترتكز على قاعدة إسطو انية من الرخــام أيضًا، ويتفر ع من منتصف هذا الحوض ذر اعان جانبيان؛ أحدهما يمتد جهة الجنوب و الآخر جهة الشمال؛ لذلك صـار هذا الحوض متعامد الثــكل على هيئة صليب أذر عه غيــر متساوية(شــكل،

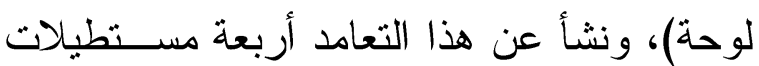

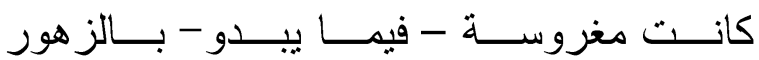
و الرياحين، يفصل بينها وبين الحوض الســابق وصفه ممر أو ممشى فرشت أرضيته بالرخــام، وهى ترتفع عن مســتوى أرضــية المســاحات

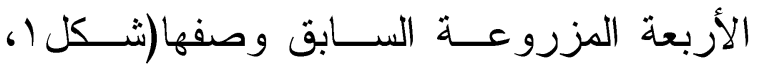
اللوحتان بr، ؟ ؟).
المدخل رفرف خشبي مائل مغطى بحطات مــن القرميد، ويوصل هــذا المــدخل إلــى إحـــى $\ddot{a}$

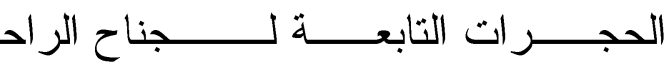
الجنوبي(شكل (، لوحة (ب). أما المدخل الثاني للواجهة الجنوبية فيقع إلـى الشرق من مثيله السابق ذكره(شكل ()، وهو يعد وفقا لما ذكره بعض الباحثين المــدخل الــــئيس للقصر (V^)، ويبلغ اتساع فتحته ، ر, ام، وارتفاعها حتى قمة عقد حدوة الفرس المدبب الذي يعلوها نحو بام، يغلق علىها باب خشبي من مصــراع

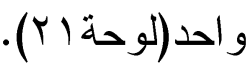

ويفضى هذا المدخل إلى دهليز يوصل بـدوره إلى داخل القصر ، يبلغ اتساعه بعد فتحة البــاب "م، ثم يقل هذا الاتساع؛ ليبلغ بم، ويبلغ طولهيم

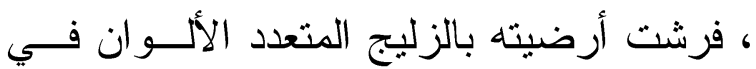
تشكيلات هندسية منتوعة، ويغطيه سقف خشبي مسطح زين باطنه بزخــارف هندســية نفــت بطريقة الحفر، ثم ينكسر هذا الدهليز في اتجــاه الشمال لمسافة قدر هابم، ويبلغ اتساعهابم أيضًا، بصدر ها فتحة باب تؤدي إلى الرواق الذي بتقدم كل من جناح الر احة الجنوبي، وقاعة الاســتقبال

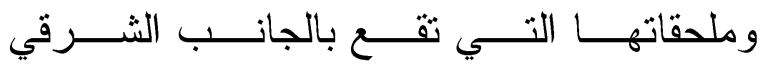
للقصر (شكل ()). و أما المدخل الثالث فيوجد بالقطــــاع الجنــوبي الشرقي لهذه الواجهة الجنوبية، وتثقدمه مســاحة مكشوفة يتوصل إلبها من خلال ســلم صـــاعد كسيث درجاته وجوانبه بالزليج، ماز الت بقاياها (ل) (لبلة مطماطى: الزليج على العمائر الدينية والمدنية

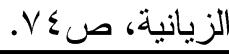


ع - قاعـــــة الاســــتقبال (شـــــــ/ A

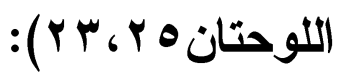

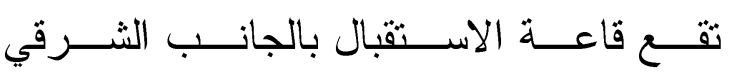

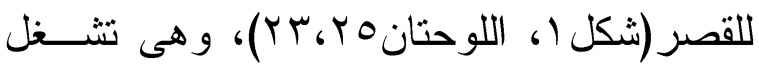
مساحة مستطيلة الثكل يبلغ طولها من الثـــمال

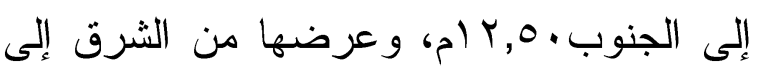

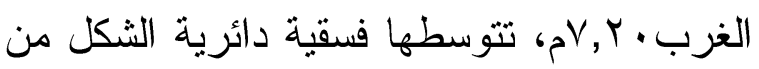

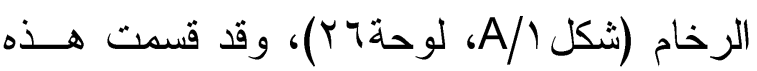

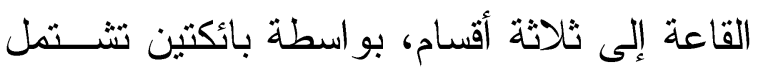

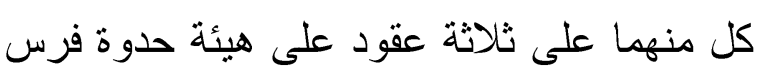

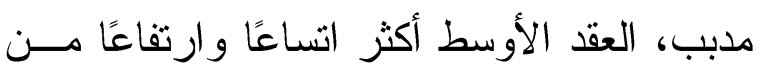
الجانبين، نرتكز هذه العقــود علــى دعــامتين مستطيلتين في الوسط، وكتهـين بنــائيين فــي لـي

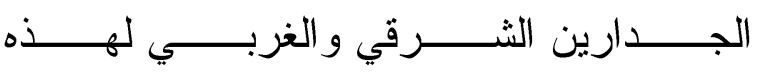

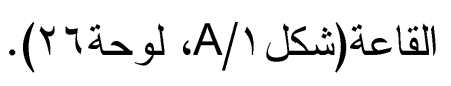

ويلاحظ أن القسم الأوسط لهذه القاعـــة أكثـــر

اتساعًا من الجانبين؛ حيث يشغل مساحة مربعــة

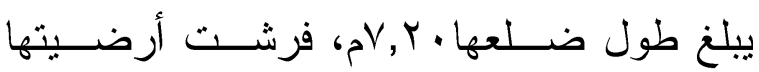

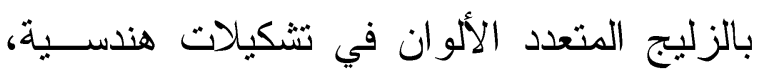

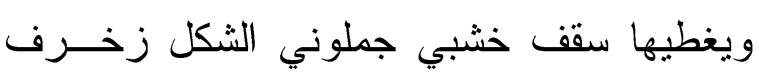

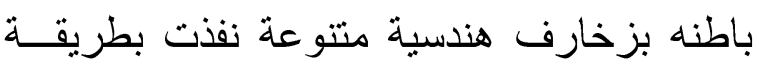

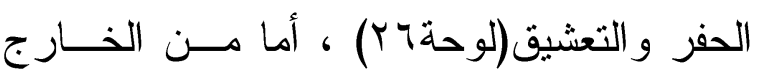
فغطي بحطات من القرميد(لوحةهب)، ويتوصل ، لمان

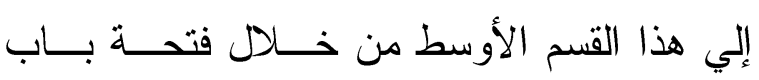

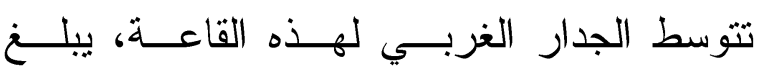

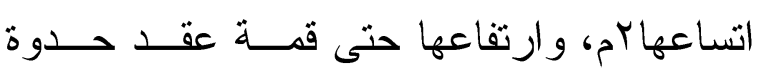

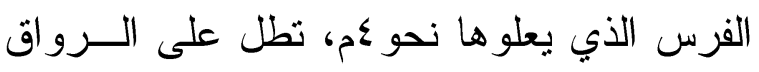

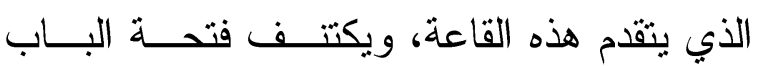
السابق وصفها نافتتان مستطيلتان يعلو كل منهما
ب-الأروقة التي تحيط بالصحن:

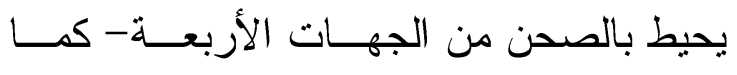

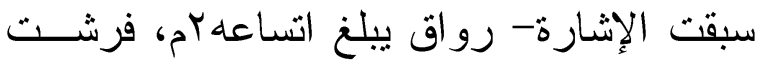

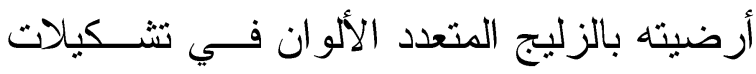
هندسية، ويغطيه سقف خشبي مسطح زين باطنه

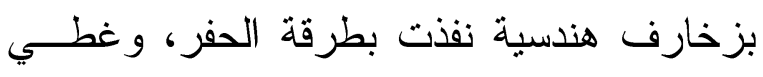

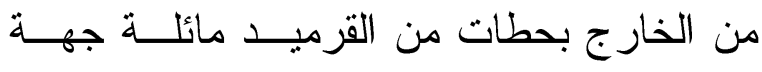

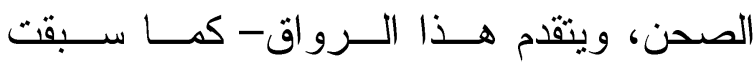

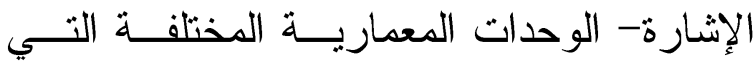

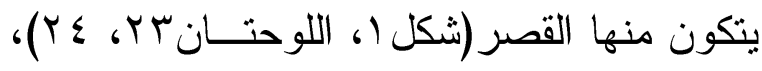
ويطل هذا الرواق على الصحن بأربع واجهات،

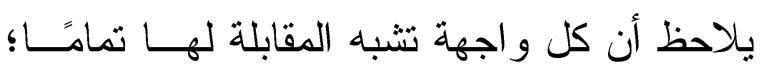

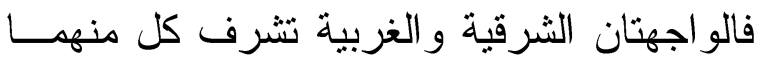

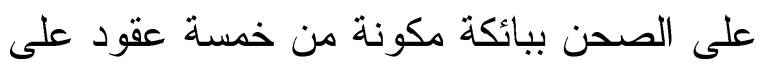

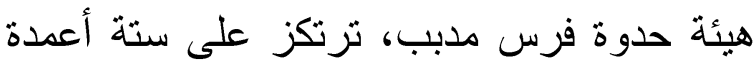

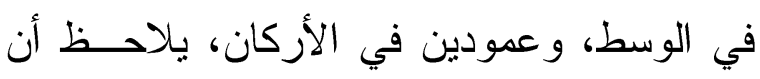

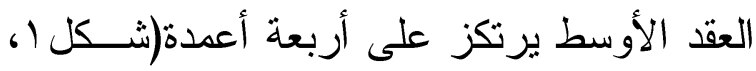

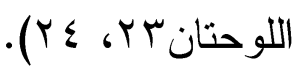

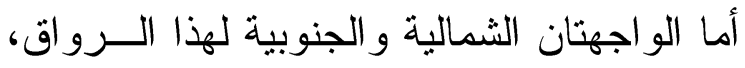
فتطل على الصحن ببائكة مكونة من أحد عشــر

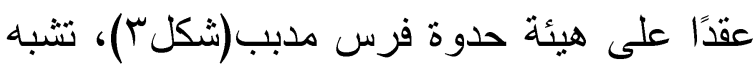

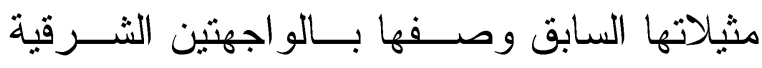

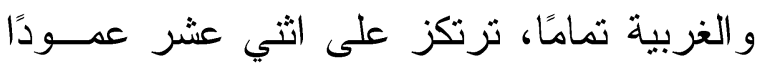

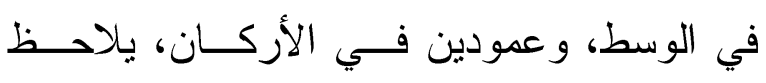

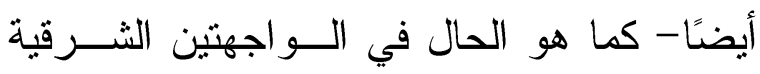
و الغربية- أن العقد الأوسط يرتكز على أربعــة

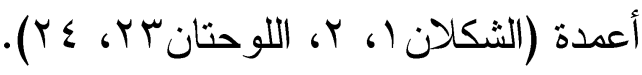


بزخارف هندسية متنوعة، وقد كانت هذه الحجرة

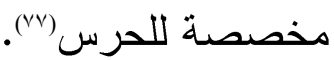

\section{ه-جناح الحريم (شكل /B/ اللوحتان ع r،} $:(Y \vee$

يتوسط جناح الحريم الجانـب الغربــي مـنـ القصر (شكل B/B، لوحةء r)، وهو يتكون مسن مستويين همــا: الــدور الأرضــي، و الطـــابق الأول(لوحة؛ ب)، يشتمل الدور الأرضي علـى قاعة يكتنفها من الجهتين الثــمالية و الجنوبيــة امتداد الرواقين الشمالي والجنوبي للرواق الــذي

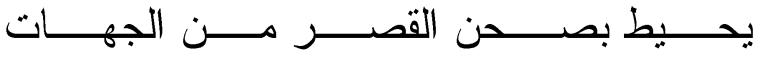
الأربعة(شكل B/ لوحة؛ Y)، تشخل هذه القاعة مساحة مستطيلة الثكل يبلغ طولها من الثــمال إلى الجنوب. ب, أم، و عرضها من الثرق إلى الغرب • ^,هم، ويتوسط جدارها الثرقي فتحـــة باب تشبه فتحة الباب التـي تتوســط جــــار ها الغربي، وتقع على نفس محور ها، تفضي إلـى

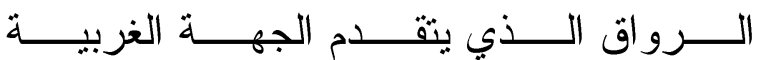

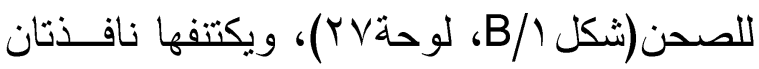
مستطيلتان يعلو كل منهما عقد على هيئة حــدوة فرس، ويغلق على كل منهما شباك خشبي مــن

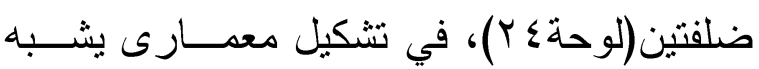
و اجهــة قاعــة الاســتقبال الســـابث وصـــهـا

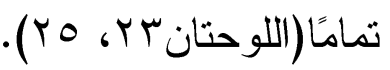

وقد قسمت هذه القاعــة إلــى ثيلاثـــة أقتــــام، بو اسطة بائكتين تشتمل كل منهما علــى ثلاتــة
عقد على هيئة حدوة فرس، ويغلق علـى كـلـ منهما شبالك خشبي من ضلفتين (لوحةه ب). أما القسمان الجانبيان فمشتابهان ثمامًا؛ حيـــث يشغل كل منهما مساحة مستطيلة يبلغ طولها من الشرق إلى الغرب. • Y, Vم، بينما يبلغ اتساعها من

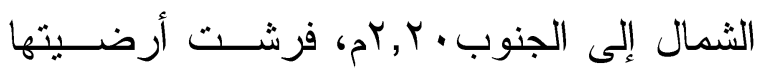
بالزليج المتعدد الألوان في تشكيلات هندسـية، ويغطيها سقف خشبي جملوني الشكل زخــرف باطنه بزخارف هندسية متتوعة نفذت بطريقــة الحفر والتششيق، أما من الخارج فغطي بحطات من القرمبد، ويطل كل قسم منهما على المساحة الوسطى السابق وصفها ببائكة مكونة من ثلاتــة عقود على هيئة حــدوة فـرس مــدبب ســـق وصفها(شكل /A/، لوحةه ب)، ويتوصل إلي كل قسم منهما من خلال فتحة باب تتوسط الجــدار

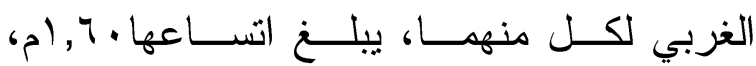
وارتفاعها حتى قمة عقد حــدوة الفــرس الــذي يعلوها نحوسّم، تطل على الرواق الذي يتقدم هذه القاعة، وإن كان ثمة اختلاف بين هذين القسمين فيتمثل في أن الجدار الشمالي للقســم الثـــمالي يتوسطه فتحة باب تفضي إلى حجرة مســنيلة الشكل يبلغ طولها من الثرق إلى الغرب. • Y.

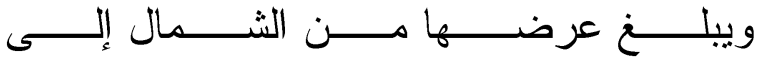

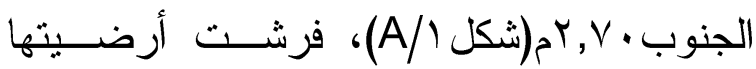
بالزليج المتعدد الألوان في تشكيلات هندسـية، ويغطيها سقف خشــبي مســـح زيــن باطنــهـ 
الأول لجناح الحريم(شكل اB/، لوحة.r)، أهــ

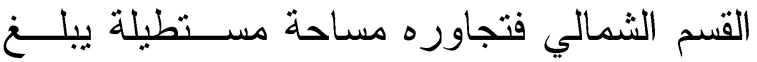
طولها من الشرق إلى الغرب •ـ,هم، بينما يبلـــغ

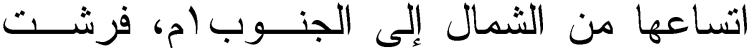
أرضيتها بالزليج المتعدد الألوان في تثـكيلات هندسية، يتوصل إليها من خلال فتحتـي بــابين بجدارها الثمالي تفتحان على الرواق الذي يتقدم

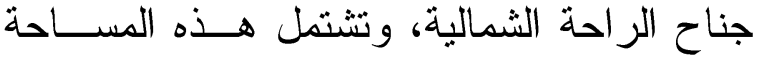
على سلم صاعد يوصل للطــابق الأول لجنـــاح الحريم(شكل (B/). أما الطابق الأول لجناح الحريم فيشنمل عالـى لى

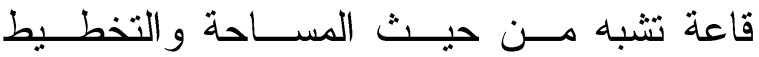
المعماري قاعة الدور الأرضي السابق وصفها،

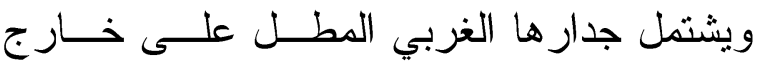
القصر على نافذتين مستطيلتين بعلو كل منهــــا

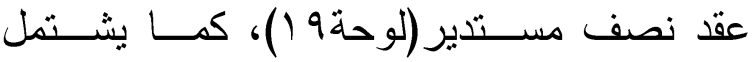

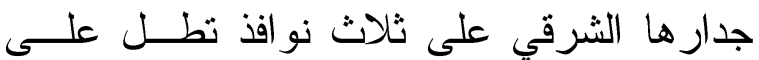
صدن القصر، تشبه مثيلاتها الســابق وصــفها

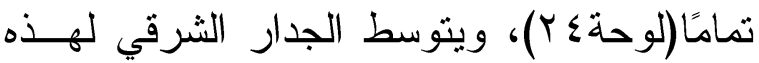

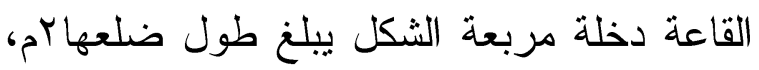
غطيت بسق خشبي جملوني الثكل زين باطنه بزخارف هندسية متتوعة، ويأخذ هذا السقف من الخارج هيئة هرمية الثكل غطيت بحطات مسن لـن

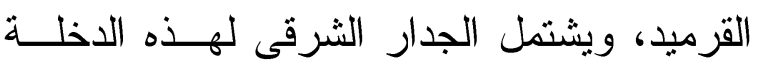
على ثلاث نو افذ مسنطيلة الشكل يعلو كل منهـــا

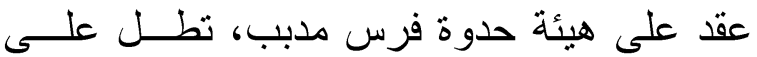
صحن القصر (لوحة؛ ب).
عقود على هيئة حدوة فرس مدبب؛ العقد الأوسط أكثر اتساعًا وارتفاعًا من الجانبين، ترتكز هــــهـ

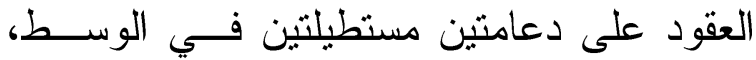
وكتفين بنائيين في الجدارين الثرقي و الغربـي

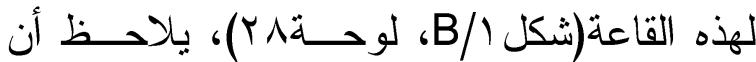

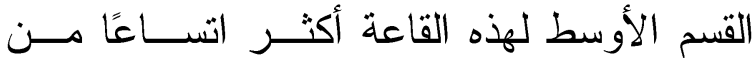

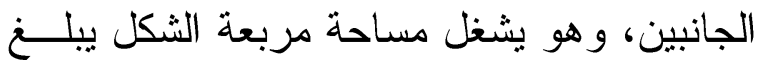

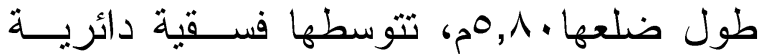
الشكل من الرخام، غير موجودة حاليَّا، ولكــن

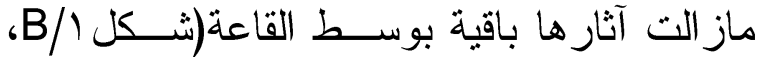
لوحةVY)، محاطة بأربعة أعمدة أسطو انية الثكل الثل من الرخام، وفرشت أرضية هذا القسم بـالزليج

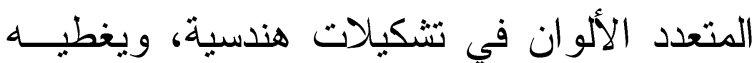
سقف خشبي جملوني الشكل زين باطنه بزخارف

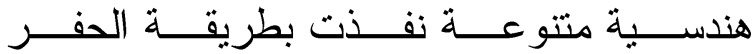
و التعشيق(لوحةمبr). أما القسمان الجانبيان فمتشابهان إلى حد مــا؛

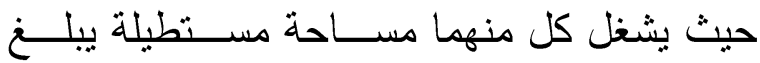

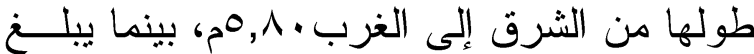

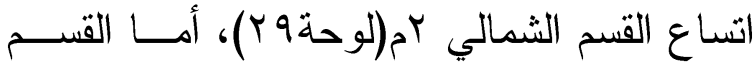
الجنوبي فيبلغ اتســاعهام (لوحسـة ، ب)، فرشــت

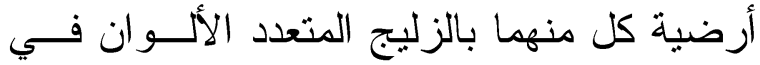
تشكيلات هندسية، ويغطيه سقف خشبي جملوني الثكل زين باطنه بزخارف هندســبة متتوعـة، ويطل كل قسم منهما على القسم الأوسط السابق وصفه ببائكة مكونة من ثلاثة عقود على هيأـــة

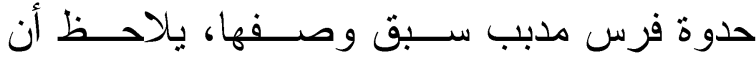

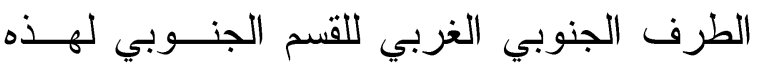
القاعة يشتمل على سلم صاعد يوصل إلى الطابق 
بزخارف هندسية متتو عة، و غطي من الخــارج بحطات من القرميد(لوحة اسب). وبكل من الطرف الجنوبي الغربــي للجــدار الغربي لهذه القاعة و الطرف الجنوبي الثــرقي لجدار ها الشرقي توجد فتحة باب، التي بالجـــدار الغربي تفضي إلى الحجرة الثانية التابعة لهـــا الجناح، كما يتوصل إلى هذه الحجرة من خــلال إلى فتحة باب يتوســط جــدار ها الجنــوبي، يبــــغ اتساعها • T, ام، وارتفاعها نحو بم، يخلق عليهــا باب خشبي من مصر اعين(لوحة اسب)، وتشــل هذه الحجرة مساحة مربعة الثكل تقريبًا، يبلــغ طولها من الثمال إلى الجنوب •ـ,"rم، وعرضها من الشرق إلى الغرب. • V, ام، تتوسطها فسـقية دائرية الشكل من الرخام(شكل /C/)، وقد فرشت

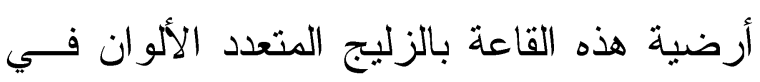
تشكيلات هندسية، ويغطيها سقف خشبي جملوني الثكل زين باطنه بزخارف هندسـية متنو عــة، وغطي من الخــار ج بحطــات مـــن القرمبــد، وبالطرف الثمالي الشرقي لجـــدار ها الثــمالي توجد فتحة باب توصــل إلـى رواق مســنطيل الشكل يبلغ طوله من الثرق إلى الغرب، •, 9, م، و عرضه من الشمال إلى الجنوب ، ع, ام، فرشت أرضيتها بالزليج المتعدد الألوان في تشــيلات هندسية، ويغطيها سقف خشبي مسطح زين باطنه بزخارف هندسية متنوعة، كان يوصل إلى حمام القصر المجاور لهــذه الحجـرة مــن الناحيــة الغربية( (C/ (شكل (C/).

دلبلة مطماطى: الزليج على العمائر الدينية و المدنية
צ-جناح الراحة الثـمالي (ثـكل C/C)،

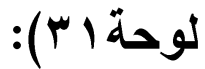
يتوسط جناح الراحة الشمالي الجانب الثــمالي للقصر (شكل C/C)، وهو يتكــون مسـن ثــلاث حجرات متفاوتة فيما بينها من حيث المســاحة، يلاحظ أن أوســطها أكبـر مــن الحجــرتين الجانبيتين، ويتوصل إلبها من خلال فتحة بــاب تتوسط جــدار ها الجنــوبي يبلــنغ اتســـاعهابم، وارتفاعها حتى قمة عقد حــدوة الفــرس الــذي يعلوها نحو عُ، يغلق عليها بــاب خشــبي مـــن مصر اعين(لوحة اب)، وهــى تشــل مســاحة مستطيلة الشكل، يبلغ طولها من الثــرق إلـى الغرب Y (م، بينما يبلغ عرضها من الشمال إلـى هـ الجنوب، (,"ام، تتوسطها فسقية دائرية الثــكل

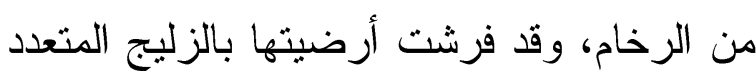
الألو ان في تشكيلات هندسية، ويغطيهــا ســق تره خشبي جملوني الشكل زين باطنـــهـ بزخــارف هندسية مثتو عة نفذت بطريقة الحفر، و غطي من الخارج بحطات من القرميد، يتوســط الجــدار الشمالي لهذه الحجرة دخلة مستطيلة الشكل يبلغ عمقها من الشمال إلى الجنوب آم، واتساعها من الشرق إلى الغرب ام، وبالقطاع الشرقي للجدار الشمالي لهذه الحجرة توجد فتحة باب توصل إلى

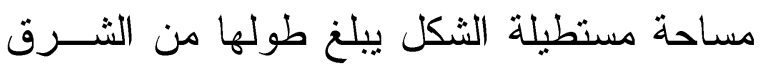

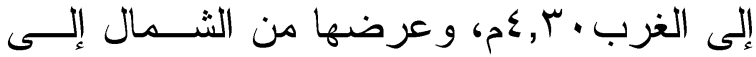

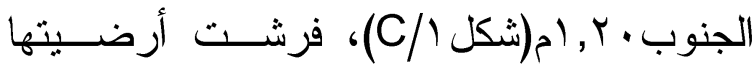
بالزليج المتعدد الألوان في تشكيلات هندسـية، ويغطيها سقف خشبي جملوني الشكل زين باطنه 
هندسية، ويغطيها سقف خشبي مسطح مزخرف بتشكيلات هندسية متتو عة.

V-جنــاح الر احــة الجنوبي(شــكل I/

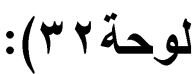
يتوسط جناح الراحة الجنوبي الجانب الجنوبي

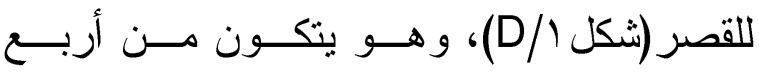
حجرات متفاوتة فيما بينها من حيث المســاحة، يلاحظ أن أوسطها أكبر من الحجــرات الثلاتــة الأخرى، ويتوصل إليها من خلال ثلاث فتحات أبو اب بجدار ها الشمالي، يلاحظ أن أوسطها أكثر اتساعًا وارثفاعًا يبلغ اتساعها بم، وارتفاعها حتى

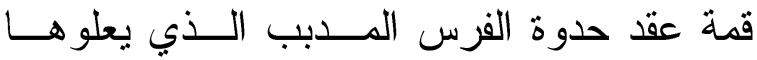

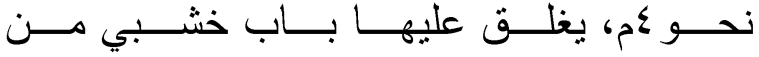

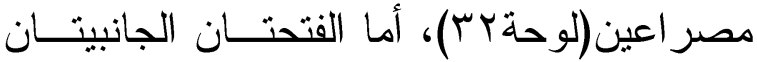

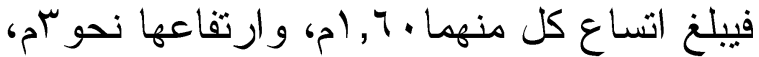

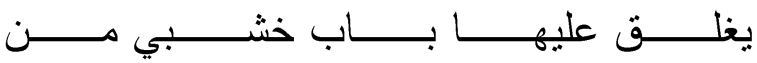
مصر اعين (لوحةبץ)، وهـــى تشـــل مســاحة مستطيلة الشكل، يبلغ طولها من الثــرق إلــى الغرب •^, ب اج، بينما يبلغ عرضها من الثــمال

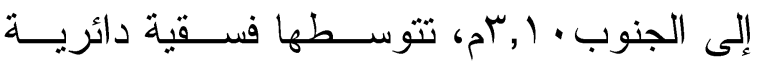

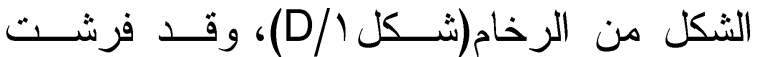
أرضيتها بالزليج المتعدد الألوان في تشــيلات هندسية، ويغطيها سقف خشبي جملوني الثــكل زين باطنه بزخارف هندسـية نفــت بطريقـة الحفر، و غطي من الخارج بحطات من القرميد، يتوسط الجدار الجنوبي لهــذه الحجــرة دخلـــة مستطيلة الثكل يبلغ عمقها مــن الثــمال إلــى الجنوبسم و اتساعها من الثرق إلى الغرب مج، يلاحظ أنها تبرز عن سمت الواجهـــة الجنوبيـــة
أما فتحة الباب التي بالطرف الجنوبي الشرقي للجدار الشرقي للحجرة الوسطى لجناح الراحسـة

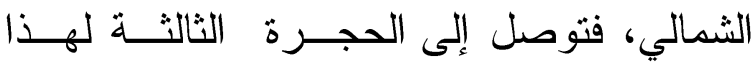
الجناح، التي يتوصل إليها أيضًّـا، مــن خــلاله فتحتي بابين منتابهتين تماكًا، بجدارها الجنوبي، يبلغ اتساع كل منهما • ج, (م، و ارتفاعها نحو بم،

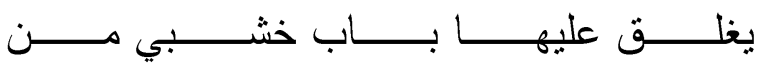
مصر اعين(لوحة اب)، وتشـــل هـــهـ الحجــرة مساحة مستطيلة الثكل يبلغ طولها من الثــرق إلى الغرب • r, • (م، و عرضها من الشمال إلـى الجنوب إش(شكل /C/)، فرشت أرضيتها بالزليج المتعدد الألوان في تشكيلات هندسية، ويغطيهـا سقف خشبي جملوني الشكل زين باطنه بزخارف هندسية منتوعة، أما من الخارج فغطي بحطات من القرمبد، وبصدر ها فتحة باب تــؤدي إلــى مساحة مستطيلة غير منتظمة الشــكل، فرشــــ أرضيتها بالزليج المتعدد الألوان في تشـكيلات هندسية، ويغطيها سقف خشبي مسطح مزخرف بتشكيلات هندسية متتوعة، وبالقطاع الثــمالي الغربي للجدار الثمالي لهذه الحجرة توجد فتحة باب توصل إلى مساحة مستطيلة نشــتمل علـى يمين الاخل على سلم صاعد يؤدي إلى ســطح القصر ، وبالطرف الثــمالي الغربــي للجــــار الشمالي لهذه المساحة المستطيلة توجد فتحة باب تفضي إلى حجرة مستطيلة الشكل يبلغ طولها من

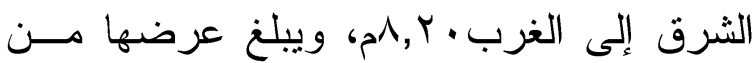

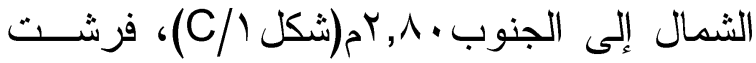
أرضيتها بالزليج المتعدد الألوان في تشـكيلات 
الغـــربلام، وعرضـــها مــن الثـــمال إلــى الجنوب بم(شكل (D/)، فرشت أرضيتها بالزليج المتعدد الألوان في تشكيلات هندسية، ويغطيهـا سقف خشبي جملوني الشكل زين باطنه بزخارف هندسية متنوعة نفذت بطريقة الحفر ، غطي من الخارج بحطات من القرميد(لوحةبr). ويلاصق الجدار الغربـي للحجــرة الســـابق وصفها الحجرة الرابعة التابعة لجنــاح الراحسـة

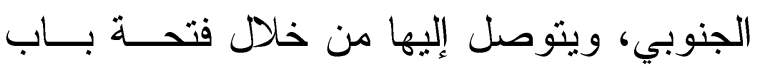
بالطرف الثمالي الثرقي لجــــارها الثـــــي،

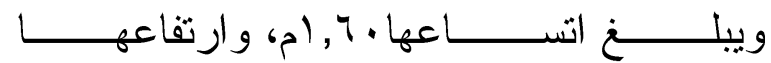
نحو بم(شكل الم/D)، يغلق عليها باب خشبي مسن

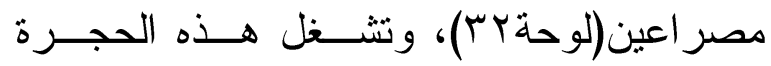

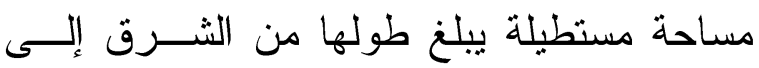

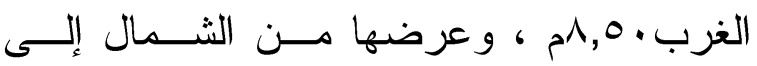
الجنوب ع(شكل (D/)، فرشت أرضيتها بالزليج المتعدد الألو ان في تشكيلات هندسية، ويغطيهـا سقف خشبي جملوني الشكل زين باطنه بزخارف هندسية متتوعة نفذت بطريقة الحفر، ويعلو هذا

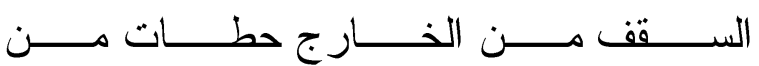
القرميد(لوحةrr).

\section{الدراسة التحليلية: - الية}

وضح من الدراسة الوصفية لقصــر المشـــور

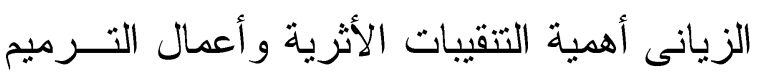

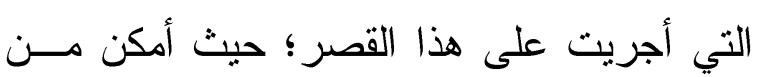
خلالها، كما سبقت الإثــارة، إعادتــه لحالتــهـ الأصلية- إلى حد كبير - بصورة كاملة، كإضافة مهمة إلى العمائر الزيانية بوجه خاص، وعمائر

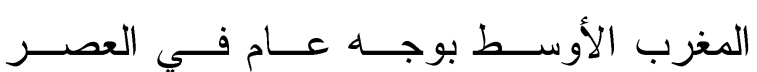

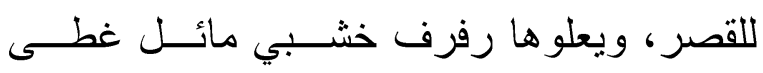
بحطات من القرميد(شكل D/ الوحة (Y).

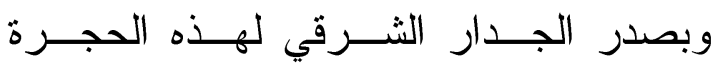
الوسطى لجناح الراحة الجنوبي توجد فتحة باب

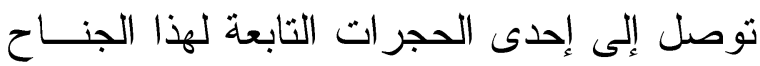

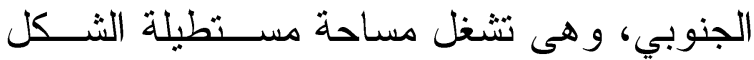

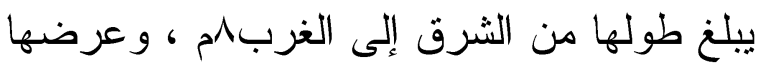

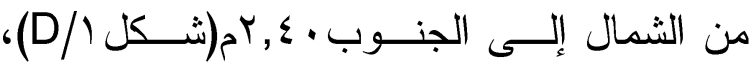

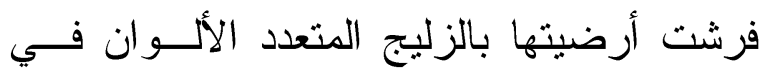

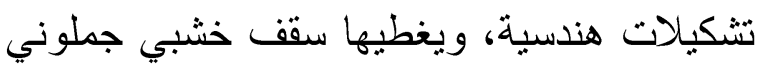
الشكل زين باطنه بزخارف هندسـية متتوعــة

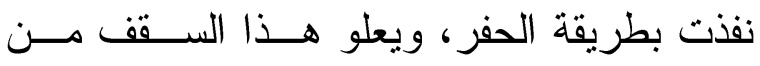

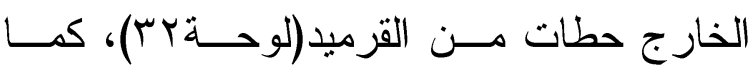
يتوصل إليها أيضًا، من خلال فتحة باب تتوسط

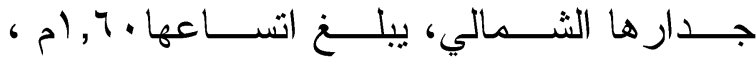
وارتفاعها نحو سام، يغلق عليها باب خشبي مـن لـن مصر اعين(لوحة بr).

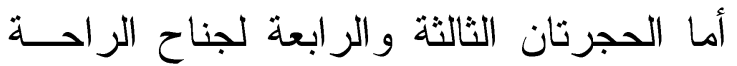
الجنوبي فنقعان إلى الغرب من الحجرة الكبــرى الرئيسة السابق وصفها؛ إحداهما تلاصق جدارها الغربي مباشرة، ويتوصل إليهــا مــن خــارج القصر ؛ حيث يتوسط جدار ها الجنوبي فتحة باب ولني

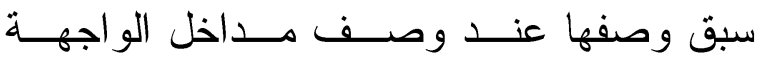

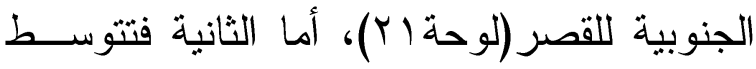
جدارها الثمالي المطل على الرواق الذي يتقـــدم

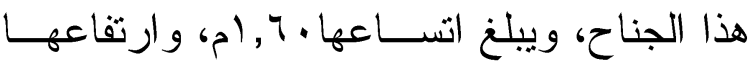

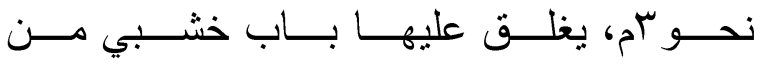

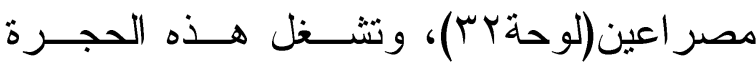

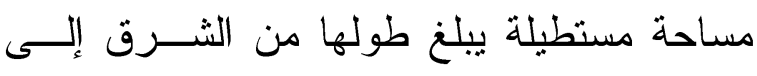


بلحسن الذي شيد في عهد أبي سعيد عثمان بـن

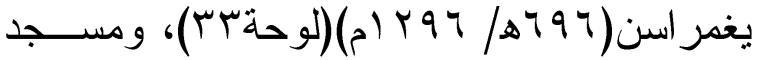

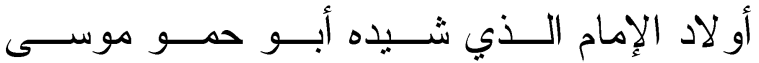
الأول(· الهـ| • آسام)، ومسجد سيدي إير اهيم

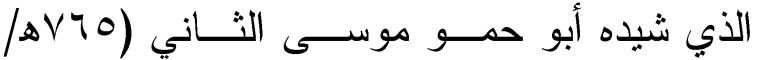

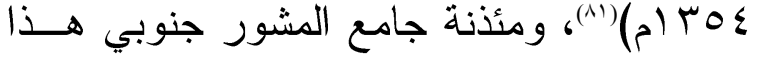
القصر الذي شيده أبو حمو موسى الأول بدايــة

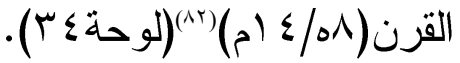

فضلا عن بعض لوحات الفسيفســـاء الخزفيــة التي ترجع إلى المدرسة التاشفينية التي شـيدها

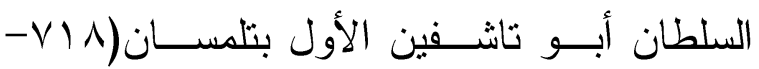


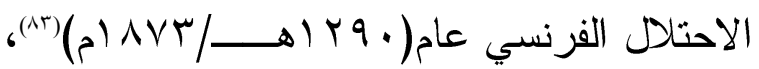
و هى محفوظة حاليًا، بالمتحف الوطني للآثـار

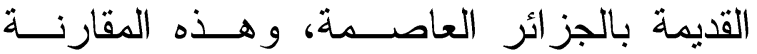
أسهمت - و لا شك- في دقة أعمال الترميم التـي وني أجريت على هذا القصر ؛ وهى تكمل مع البقايـــا المعمارية و الزخرفية لقصر المشور صورة هذا

$$
\text { القصر في عصر ازدهاره. }
$$

وعلى أية حال، وضح من الدراسة الوصـفية لقصر الشور الزيانى أنه يشغل مساحة مستطيلة

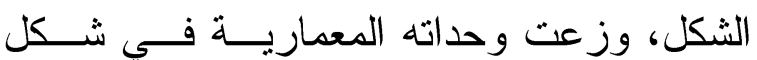

${ }^{81)}$ Marçais, W., et G., Les Monuments Arabes de Tlemcen pp. 170-171,185,302303; Bourouiba, L'Art Religieux Musulman p. 171.

(بr) L'Art Religieux Musulman, p.171 Bourouiba, الزبالية، صنيلة مطماطى: الزليج على العمائر الدينية و المدنية

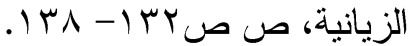

الإسلامي، وبخاصة المدنية منها، و لا ســيما أن

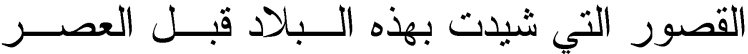

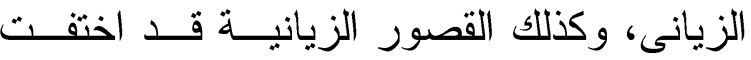
تمامًا- كما سبقت الإشارة- ولم يبق دليل عليها سوى الروايــات التـي تتضــــها المصـــادر

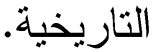

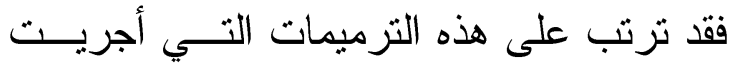
على قصر المشور، الحفاظ على بقاياه المعمارية و الزخرفية، و إعادة تثــكيلها و اســتكمالها دون

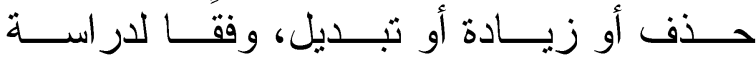

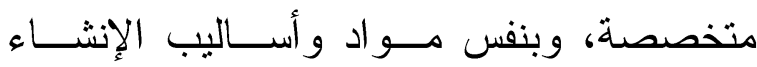
المستخدمة في بناء هذا القصر، كما لـــ يغفـلـل القائمون على هذه التزميمات مقارنة بقايا هـــا القصر عمارة وزخرفة بكثيــر مــن المنشــآت الزيانية الباقية بمدينة تلمسان و المعاصرة لتاريخ

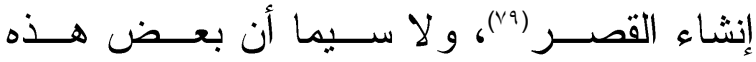

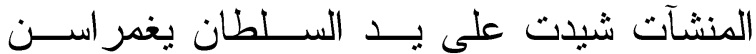
مؤسس هذا القصـر(rrT-1)

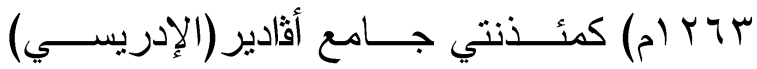
و الجامع الكبير (المر ابطى)(•)، و البعض الآخــر من هذه المنشآت شيد على يد أبنائه الذين أسهوا النهوا

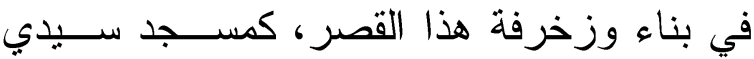

(199) هذا وفقًا للرواية الثفهية التي ذكرها لي المهنس/ شيعلى عبد الصمد المشرف على مشروع ترميم قصر

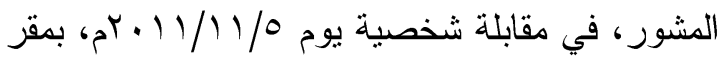

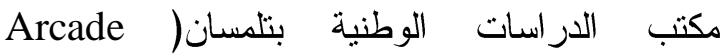
.(Tlemcen (·) دليلة مطماطى: الزليج على العمائر الدينية والددنية

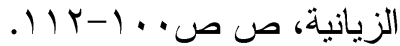


بكمية كافية مــن أشـــعة الثــمس و الإضـــاءة و التهوية.

وتبدأ عناصر الاتصـال بهذا القصر من خــلال

المداخل التي تربطهـــــــالمســاحات المحيطـــة بالقصر مباشرة دون وجود ســلالم؛ نظــرًا لأن أرضية هذا القصــر بــنفس مســتوى أرضـــية المساحات المحبطة به، ويشتمل القصر على ستة مداخل - كما سبقت الإشارة- - موزعة علــى: ثلاثة مداخل بالواجهة الغربية توصل إلى جناح

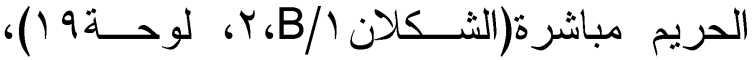
و الثثاثة الأخرى على الو اجهة الجنوبية؛ أحــــها يفضي إلى إحدى الحجرات التابعة لجناح الراحة الجنوبي، و المدخلان الباقيــان يوصـــلان إلــى الرواق الذي يتقدم قاعة الاستقبال(شكل ()، بينما لا تشتمل الو اجهتان الشرقية و الشمالية على أبــة مداخل(شكل ()؛ حيث ثقع الواجهنــان الغربيـــة و الشرقية للقصر خلف مدخل المشــور مباشــرة المعروف بـــــ(باب التويتة)، الذي يوجد بالضلع الغربي لسور المشور (الخريطتان ب، س، لوحةش)، أما الواجهة الثمالية للقصر فلا يفصـــــاه عـن السور الشمالي للمشور ســوى بضـــعة أمتــار قليلة (لوحةب).

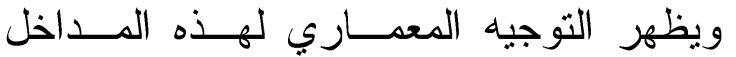
ارتباطهـــا بالوحــــات المخصصـــة للاســـتقبال بالقصر ، متمثلة في قاعة الاســتقبال بالجانــب الشرقي للقصر، وكذلك جناح الحــريم بجانبــــ

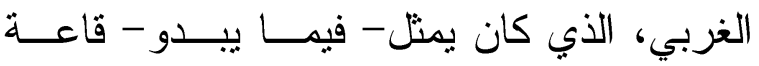

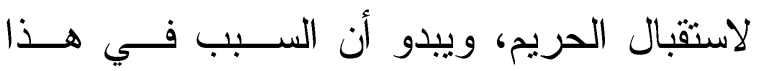
التوجيه هو وصول زوار القصر إلـى هــاتين
صفوف منقابلة ومتتاظرة حول صحن مركزي، يعد بمنزلة المحور الذي التفت حوله كل وحدات

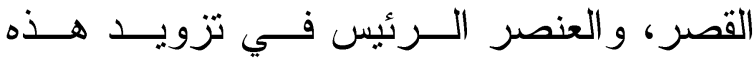
الوحدات بالتهوية والإضـاءة، من خلال انفتــاح هذه الوحدات عليه، و انعدام وجود فتحات نافــذة بجدرانها، باستثناء الطابق الأول لجناح الحــريم

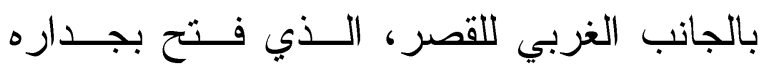

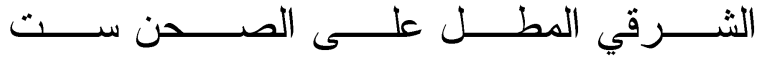

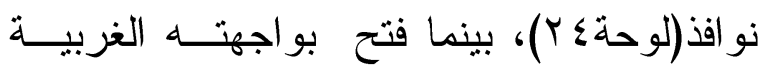

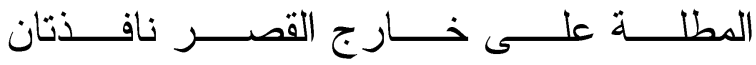
فقط (لوحة9 ()). وقد وزعت هــذه الوحــــات علــى مســاحة مستطبلة، يمتذ ضلعها الأطول من الثرق إلـى هـ هـ الغرب(شكل ())، و على هذا الضلع الطويل فـي

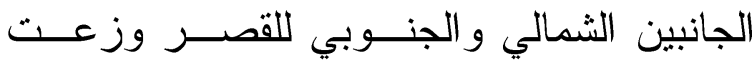
الوحدات المعمارية المخصصة للســكن، وهـى جناح الراحة الشمالي(شكل (C/))، وجناح الراحة الجنوبي(شكل D/D)، وهذا يعد التوجيه المفضــل للمباني في مدينة كتلمسان، ثقع فــي إقلــيم ذي مناخ معتدل حتى في فصل الصيف، و لا ســيما لئ أن جبال الأطلس الواقعة جنوب هذه المدينة تقبها من "رياح السموم" الآتية من الصـــحر اء، بينمــــا تهب عليها الرياح الثمالية الغربية بدايــة مــنـ

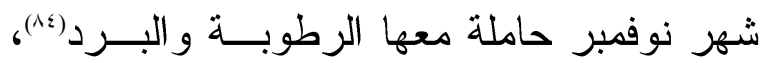
ومن ثم فإن توجيه القصر طوليا من الشرق إلى الغرب، يساعد على تمتع هذه الوحدات الســكنية الموزعة على الجانبين الشمالي و الجنوبي للقصر

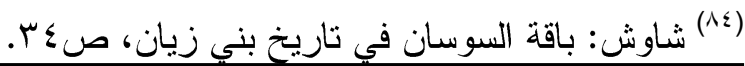


بلاد المغرب، كما هو الحال في قصر المشــور موضوع البحث، و استمر ظهوره - وفقا للنماذج

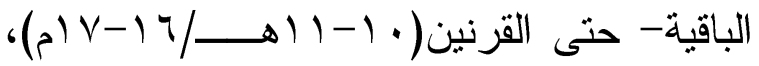
كما هو الحال في قصر البديع الســعدي، الــذي شرع في بنائه السلطان أحمد المنصور الــذهبي

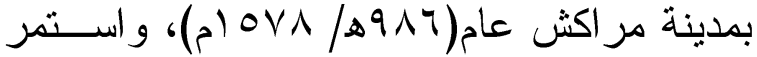

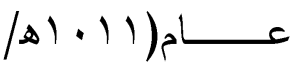
is a

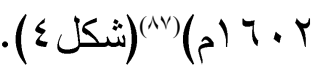

وقد شخل هذا الحوض والحدائق أو المساحات الأربعة المزروعة التي على جوانبه كل مساحة الصحن، ومن ثم اقتصرت وظيفة هذا الصــحن

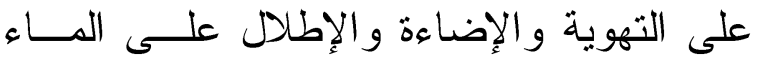

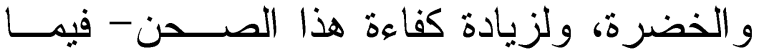
يبدو - في تزويد وحدات القصر المختلفة بالتهوية اللازمة، جاء توجيهه مائلا للاتجــاه الثــمالي الغربي، وهو اتجاه حركة الرياح السائدة بمدينة تلمسان، وللوقاية من التيار ات الهو ائية البــاردة

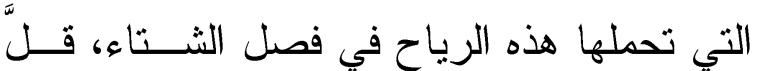
عدد النو افذ الخارجية بو اجهات هــذا القصــر،

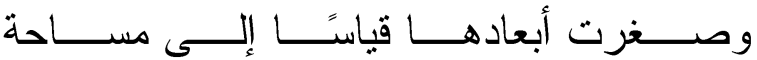
الجدران(لوحة 1 ))، و اعتمدت وحداته المعمارية المختلفة في تغذيتها بالضـــوء و الهـــواء علــى

المركز القومي للترجمة، القاهرة، ••بم، ص

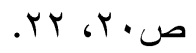

(Av) محمد أبو رحاب: قصر البديع السعدي بمدينة

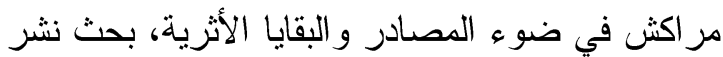
بمجلة كلية الآداب، جامعة سوهاج، العدد الثاني

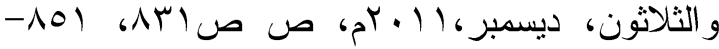

القاعتين مباشرة بمجرد اجنياز هـــه المــداخل، دون المـــرور علـــى الوحـــــات المعماريــــة المخصصة للسكن بالجانبين الشمالي و الجنــوبي للقصر (شكل (D،C/ ) ويتوسط هذا الصـــحن حــوض أو صـــهريج متعامد الشكل على هيئة صليب غيـر متســاو الأذرع (شكل ()، بكل جانب من جو انبه الأربعة، مساحة مستطيلة كانــت مزروعــة بالأزهـــار

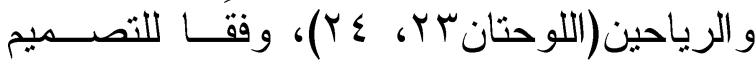
الرباعي للحدائق المقامة حول بركة أو فسـقية مركزية(10)؛ ذلك التصميم الذي شوهد من قبل في صحون القصور الإسلامية بالأنـــلس، كقصــر منتقوط (Monteagudo) الذي اكتشفت بقايــاه في سهل مرسية، وهــــ يرجــع إلــى العصــر المر ابطي (זی)، كما ظهر هذا التصميم في قصور

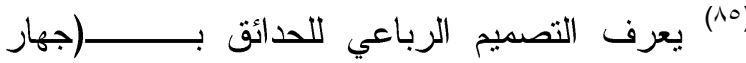

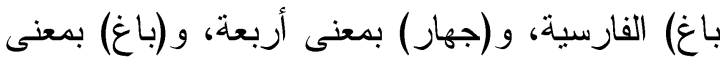

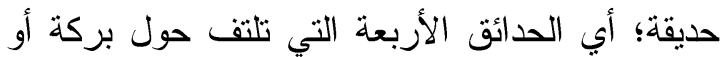

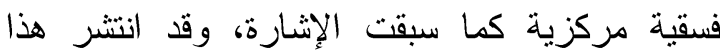
النوع من الحدائق في شرق وغرب العالم الإسلامي على حد سواء، للاستز ادة حول هذا النوع من الحدائق انظر، إيما كلارك: فن الحدائق الإسلامية، ترجمة لهن

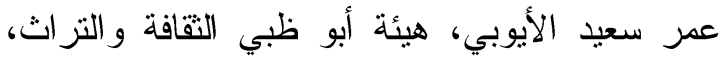

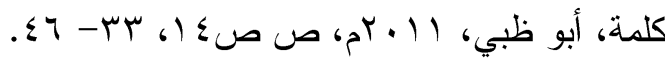
(ㄱ) توريس بالباس: الفن المر ابطي و الموحدي، ترجمة:

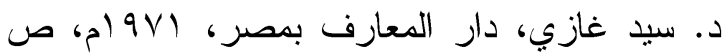
ص 9ץ- •r؟ عبد العزيز سالم: العمارة الإسلامية في الأندلس وتطور ها، ص ص 1 ـ ـ - r • (؛ باسيليو

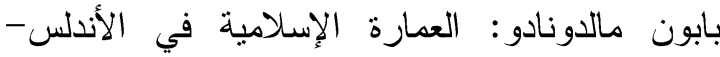
عمارة القصور، المجلد الثاني، القرن الثاني عشر، الثرن عصر المرابطين والموحدين، ترجمة على المنوفي، 
ويكثف تخطيط هذا القصر عن تتوع عناصر المنفعة، و التي تتمثل في وحدات القصــر التــي

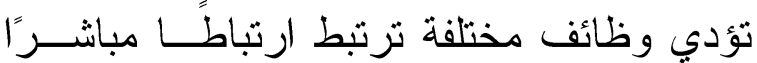
بحياة ســاكنيه، كقاعــة الاستقبال(ثــكل (A/))، وجناح الحريم(ثـــل (B/))، وجنــاح الإقامــة

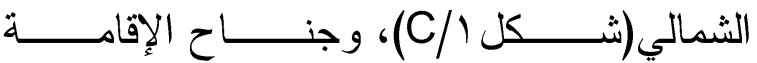
الجنوبي(شكل (D/))، و الحمام، فضلاً عن الصحن الصنا و الأروقة المحيطة به التي يتوصل منهــا إلـى

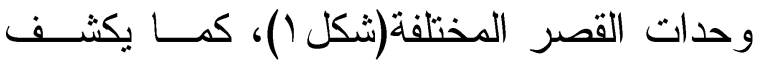
تخطيط كل من قاعة الاستقبال بالجانب الشرقي

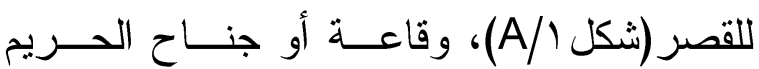

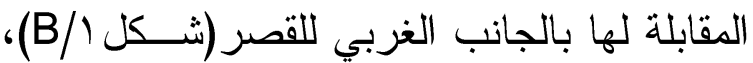
الذي اعتمد على التقسيم الثلاثـي مــن خــلاد بائكتين قسمت كل قاعة منهما إلى ثلاثة أقســام أوسطها أكثر اتساعًا من القسمين الجانبيين، أثر التنقيف و التغطية على تخطيط هاتين القاعتين، وذللك لتصغير بحر أو مساحة السقق الذي يغطي المساحة بين هذه البو ائك.

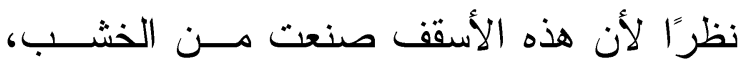

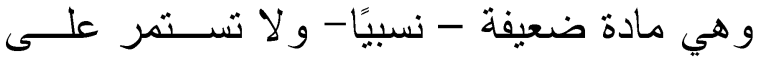
حالتها لمدة طويلة، وتحتاج إلى ترمبح وصـيـيانة في فترات متقاربة، فكان لابد من تقسيم الأسقق

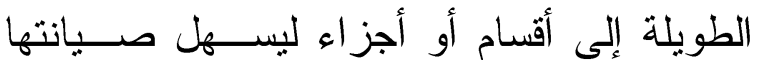
وتجديدها، لذلك جاء تخطيط هــاتين القـاعتين

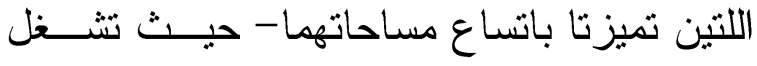

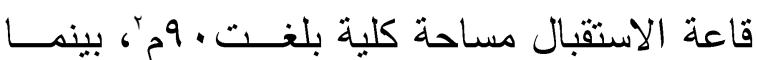

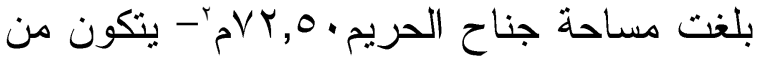
ثلاثة أقسام بواسطة بائكتين؛ تشتمل كل بائكـــة

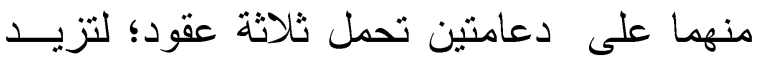

الصحن، وعلى فتحات الأبو اب و النو افذ الداخلية

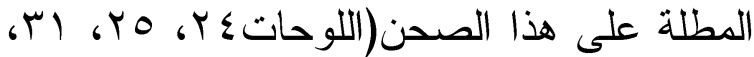

ونظرًا لاقتصار وظيفة الصحن على التهويـــة و الإضـاءة، صار الرواق الذي يحيط بهذا الصدن من جهاته الأربعة العنصر الــرئيس للاتصـــال

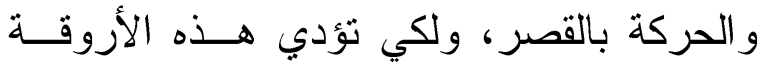
دور ها كممر ات بديلة؛ حرص المعمار علـى أن تكون متصلة لربط أجزاء القصر بعضها ببعض، و الوصول من خلالها إلى أي وحدة من وحداتــهـ المعمارية(شكل (1). فضلاً عن ذلك، فإن هذا الرواق المغطى الذي (لإن يتقدم الوحدات المعمارية التــي يتكــــن منهــا القصر، يمثل عنصر وقاية يحمي هذه الوحدات

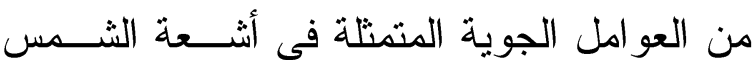
و المطر و التيار ات الهو ائية، ويمكن الانتقال مسن

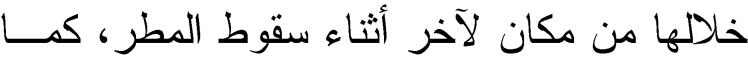

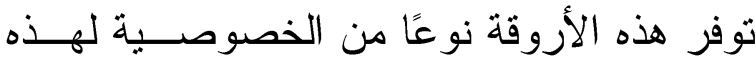
الوحدات بفصلها عن الصحن، ويطل هذا الرواق بدوره على الصحن بسلسلة من العقود، تــنعكس أنكالها - وبخاصة العقد الأوسط بكل واجهة من لن العن الواجهات الأربعة المطلة على الصحن-على ماء الحوض الذي يتوسط الصحن؛ لإضفاء مزيد من

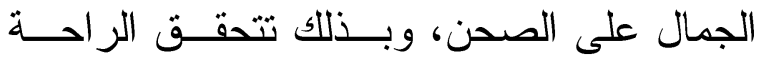
النفسية و البصرية لساكني القصــر و المتـــدددين

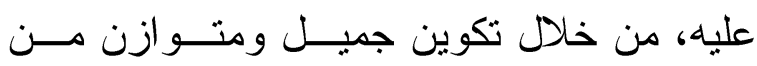

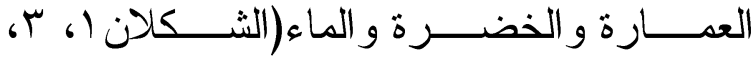

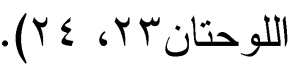


الأندلس، بعد تدفق هجرات الأندلسيين- الــذين

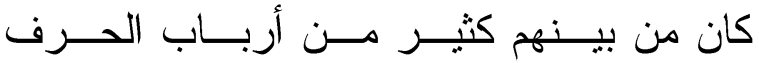
و الصناعات- إلى بلاد المغرب، على إثر تساقط

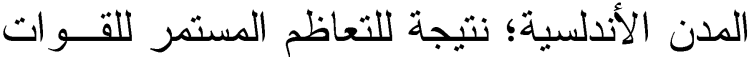
المسيحية، وتراجع القوات الأندلسية أمامها، ولم يتيق في النهاية إلا غرناطة(19a). ويعد هذا التخطيط الذي اتبعه قصر المشور موضوع البحث، من أقدم- في ضوء الندــاذج

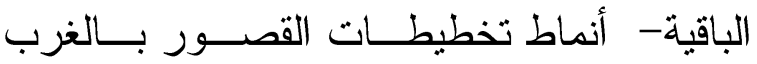

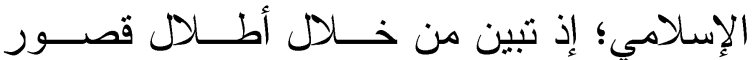

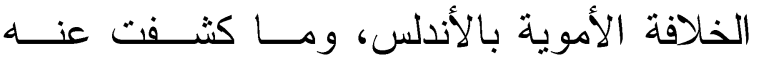

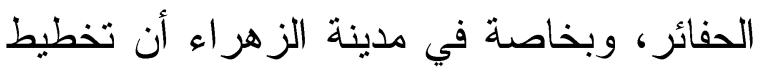
قصور ها التي شيدها كل من الخليفة عبد الرحمن

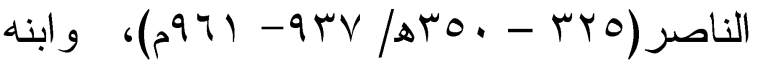

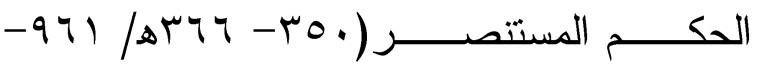

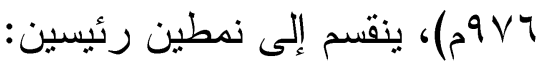

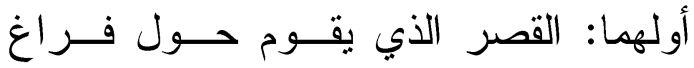
مركزي هو الصحن، وتتــوزع حولــه جميــع الوحدات المعمارية الأخرى(ه)، و الآخر: القصر الهر

محمد رزوق: الأندلسيون وهجراتهم إلى المغرب خلال القرنين 7 ا I V V، مطبعة أفريقيا الثرق، الدار

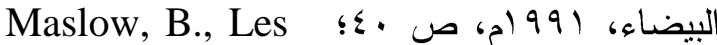
Mosquées de Fès et du Nord du Maroc, Les Éditions d'Art et d'Histoire, Paris, 1934, pp. XV- XVI.

(9.) (9بد العزيز سالم: العمارة الإسلامية في الأندلس

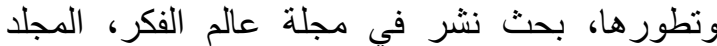

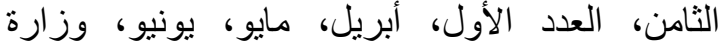

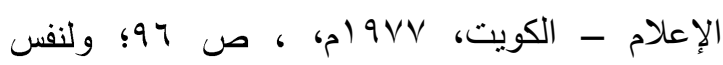
المؤلف: المساجد والقصور في الأندلس، مؤسسة شباب الجامعة، الإسكندرية، 919 (م، ، ص OV.
من الفراغ الداخلي للمبنى، ويرتكز على كل قسم من أقسام القاعة جزء من السقف، وبهذا الفصل الإنشائي نزيد متانة السقف من جهة، وتتم عملية

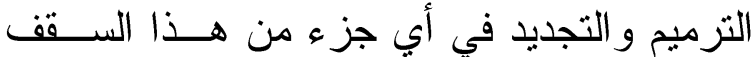

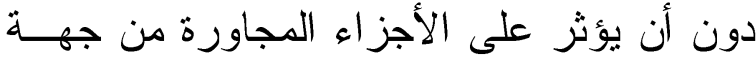
أخرى، وقد ظهر هذا التقسيم الثلاثي للقاعـات

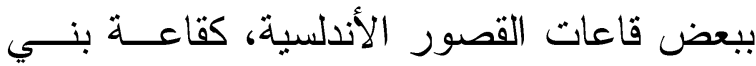
سر اج، وقاعة الأختين-على سبيل المثال - بقصر الحمر اء بغرناطة(شكل م). وعلى أية حال، يظهر تخطيط قصر المشـور الزياني، وزخارفه المتتوعة المنفذة على الزليج و الجص و الخشب تأثره بالطابع الأندلسي، وذللك انعكاس" للعلاقات الوطيدة التي كانت تربط بـين الزيانيين وبني الأحمر في غرناطة، فضلاً عـنـن استعانة سلاطين بني زيان-كما سبقت الإثارةباليد الخبيرة و الصناع المتخصصين في مختلف شئون البناء من الأندلس، وبخاصة في عهر كل من السلطان أبو حمو الأول وابنه تاثفين، حيث ذكر ابن خلدون:"واستدعى لها الصناع و الفعلـــة

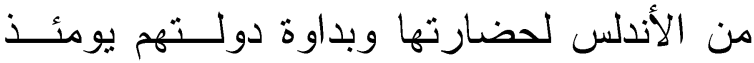
بتلمسان، فبعث إليهما السلطان أبو الوليد صاحب الأندلس بالمهرة والحذّاق من أهل صناعة البناء البهاء

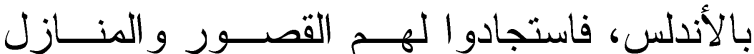
و البساتين، بما أعبا على الناس بعدهم أن بـأتوا

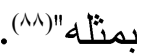

بالإضافة إلى أن تلمسان مثلت-كما ســبقت

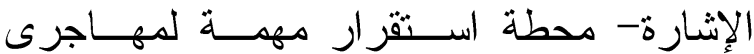

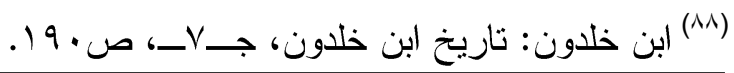


في عصر ملوك الطوائف في بهو الجص بقصر إثبيلية في عصر بني عباد، ثم أصبحت ثقليــدًا

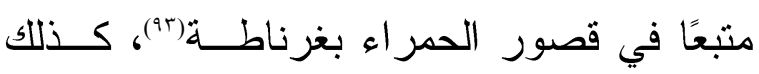
نشاهد هذه الظاهرة في قصر المشور الزيــاني موضوع البحث؛ حيث يتقدم كـلـ جنــاح مــن الأجنحة الأربعة التي يتكون منها القصــر رواق

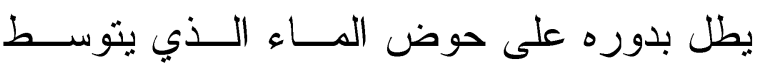
الصحن بسلسلة من العقود، يتفاوت عددها وفقًا

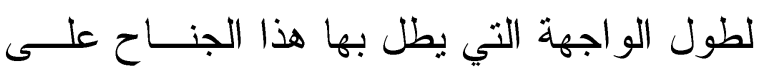

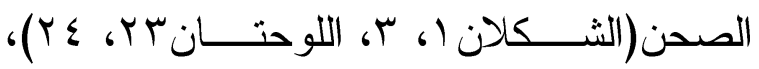
وشو هد أيضنَــا فـى قصــر البــديع الســعدي بمر اكش(شكل ع). وفي عصر ملوك الطو ائف بالأندلس بــــأت تتنشر ظاهرة البركة أو الصهريج الكبير الــذي يتوسط صحون القصور، كما هو الحــال فـي قصر طليطلة الذي شيده المأمون بن ذي النــون عام (00کـه/ بآ · (م)، و الذي وضع في وسط هذه البركة قبة زجاج ملون منقوش بالذهب(\$9). وقد شهدت قصـــور المــر ابطين و الموحــدين تطورًا و اضحًا في تخطيط صـــون القصــور ، ويظهر ذلك في قصر منتقوط الذي اكتشفت بقاياه في سهل مرسية، وهــــ يرجـــع إلــى العصــر

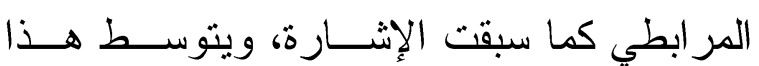
القصر صحن مستطيل الشكل يطل على ضلعيه

(9r) عبد العزيز سالم: العمارة الإسلامية في الأندلس وتطور ها، ص ص (๕) عبد العزيز سالم: العمارة الإسلامية في الأندلس صن

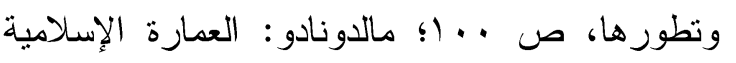

الذي يتكون تخطيطه من بلاطات منو ازية تفصل

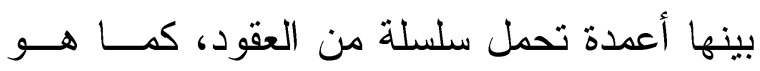
الحال في تخطبط أروقة المساجد بالأندلس('(9). كذلك كشفت حفائر الزهر اء عن قصر مــن قصور الحكم المستتصــر ، يتضــمن تخطبطـــه

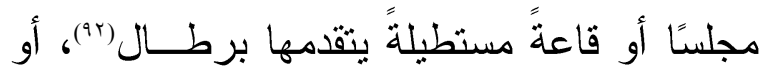
سقيفة تطل ببائكة مكونة من خمسة عقود علــى

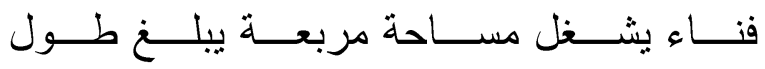
ضلعها • 9, جم، ومنذ ذلك الحين أصــبح نــــ البرطال أو البرطل الذي يتقدم المجلس أو القاعة تقليدًا متبعًا في بناء القصور حتى نهاية العصــر الإسـامي، و لاسيما إذا كان البرطل يشرف على

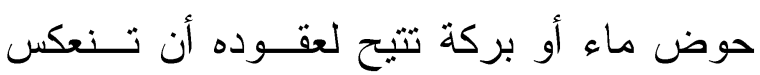
أثكالها على صفحة مياه هذه البركة؛ حيث نر اها

(91) عبد العزيز سالم: العمارة الإسلامية في الأندلس وتطورها، ص 9V ول ولنفس المؤلف: المساجد و القصور في الأندلس، ص ص OV؛ باسيليو بابون: مالدونادو: العمارة الإسلامية في الأندلس- عمارة القصور، المجلد الأول، القرن العاثر و الحادي عشر، الإدئ

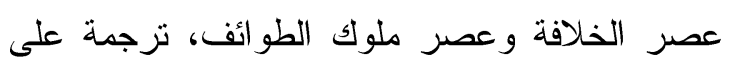

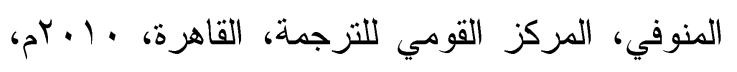
ص

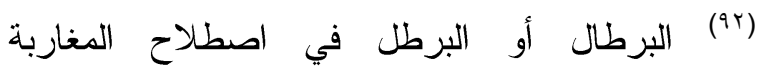
و الأندلسيين عبارة عن رواق مكون من بائكة أو أكثر

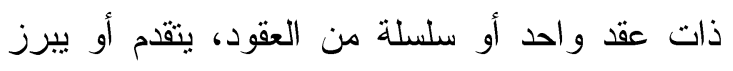

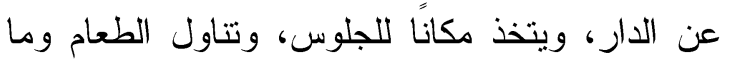
شابه ذلك. انظر، الفشتالي: مناهل الصفا في أخبار الملوك الثرفا، مختصر الجزء الثاني، تحقيق: عبد الله كنون، منشورات كلية الآداب و العلوم الإنسانية-

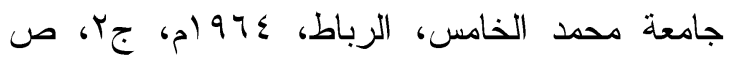
.179

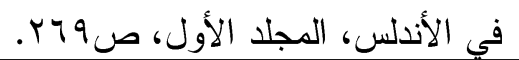


القصور الباقية بالمغرب الأوسط؛ نظرًا لاختفاء القصور التي شيدت بهذه الــبلاد قبــل العصـــر الزيانى، كما سبقت الإشارة. ويمكن القول أن ظهور الطابع الأندلسي بقوة إلى جانب التقالبد المغربية المحلية في تخطبط وزخرفة هذا القصر، يرجع إلى اشتر الك عدد من المعداريين و الصناع الأندلسيين في بنائه وزخرفته؛ حيث حرص سلاطين بني زيان على استقدام عددٍ من الصناع من غرناطة، وبخاصة في ميدان البناء وصناعة الخزف؛ للإفادة منهمكما سبقت الإشارة- في مشروعاتهم العمرانية

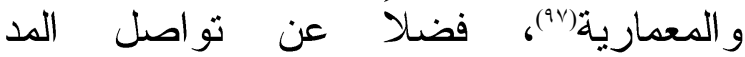
الحضاري الأندلسي في العصر الزيانى، بفضل استمرار هجرة عدد كبير من الأندلسيين من مختلف الفئات إلى المغرب الأوسط- وكذلك هن هـ المغربين الأقصى و الأدنى-، ناشرين التراث الأندلسي في هذه البلاد؛ مما كان له أكبر الأثر في نقل هذا التراث إلى بلاد المغرب من جهة، وتكوين تراث أندلسي مغربي و احد في أقطار ها الثلاثة، كان بمثابة عامل تقريب بينها وحد تصور اتها و أذو اقها و اهتماماتها، في ميادين الفكر و الثقافة إلى جانب العمارة و الفنون

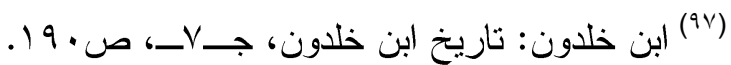

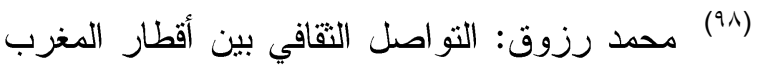
العربي (تأصيل تاريخي)، بحث نشر في كتاب

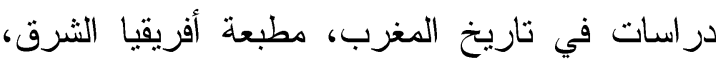

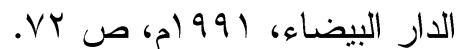

الصغيرين جوسقان مربعان بــارز ان، يمهـــدان لجوسقي فناء الأسود بقصر الحمر اء بغرناطــة، ويتعامد ممران يؤلفان محوري البناء فيما بينهما على شكل "صليب"، وتمتلئ المستطيلات الأربعة

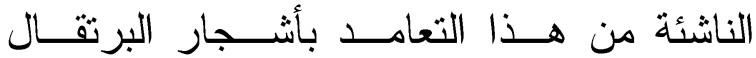
و الليمون (90)، كما هو الحال في تخطيط صـــحن قصـــر المشـــور موضــــوع البحث (شــــل

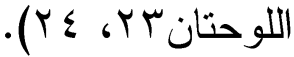

وفي عصر الموحدين بنتشر نمــط البر اطبـلـل المطلة على الصحون التـي تثوســطها بــركـ، ويتمثل ذلك في برطال يطل على بهو الجـص بقصر إثبيلية، وقد تطور هــذا التخطــيط فـي عصر بني الأحمر بغرناطة، وتمثل مجموعــة

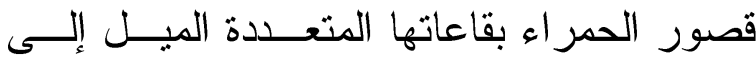

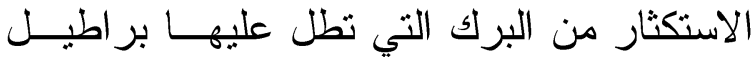
وسقائف، و انتظمت على جانبي البرك أشـــار الريحان (97)، كما هو الحال في قصــر المشــور الزياني (شكل (، لوحة بر).

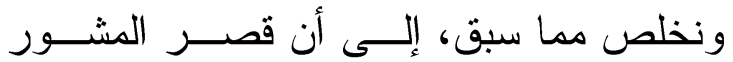
الزيانى بمدينة تلمسان كان يســتحق أن بعنــى ببقاياه عناية كبيرة، وجديرًا بالترميم و التجديــد، لما له من قيمة أثزية كبيرة، بوصفه أقدم نماذج

توريس بالباس: الفن المرابطي و الموحدي، ص ص 9ץ- •r؟ عبد العزيز سالم: العمارة الإسلامية

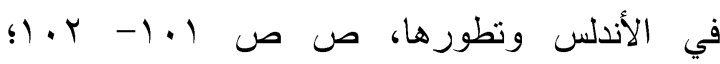
مالدونادو: العمارة الإسلامية في الأندلس، المجلد

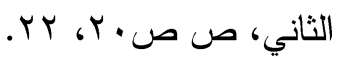
عبد العزيز سالم: العمارة الإسلامية في الأندلس 

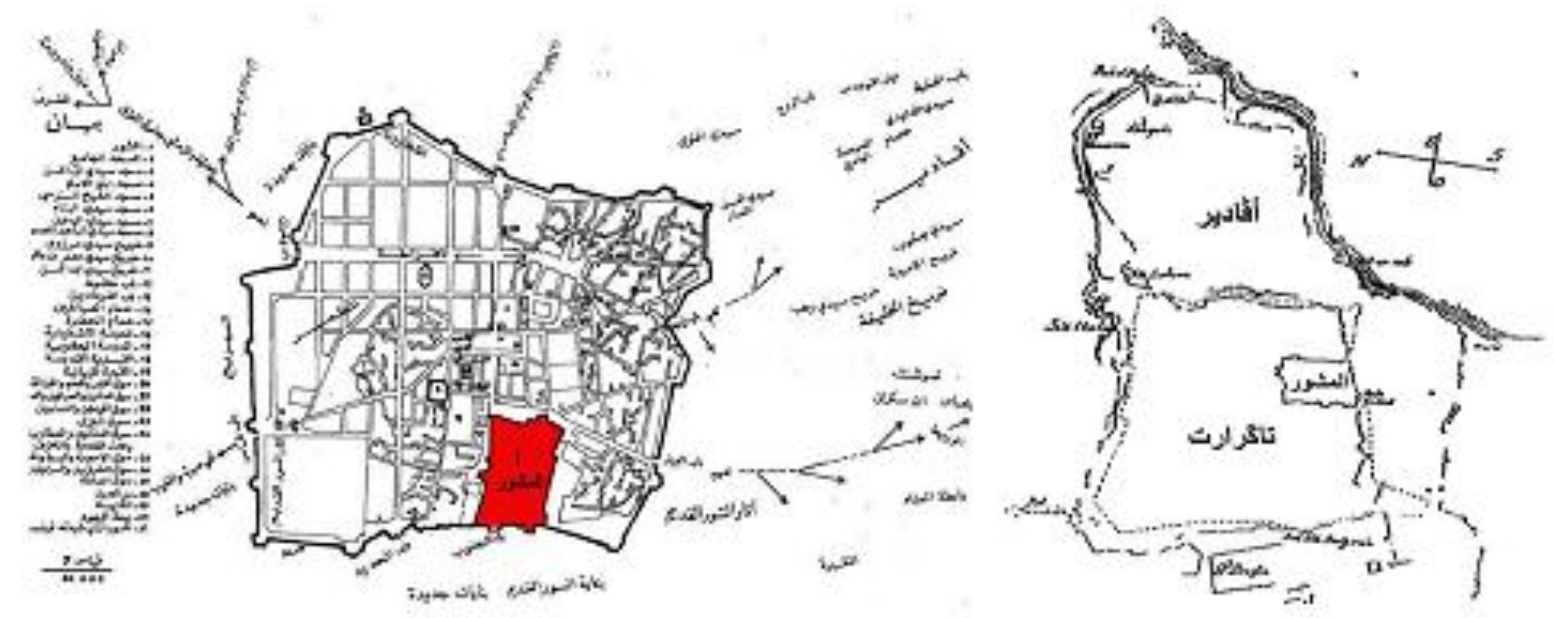

$$
\begin{aligned}
& \text { (خريطة r) مدينة تلمسان في العصر الزيانى بتصرف عن: } \\
& \text { شريفة طيان: نحاسيات تلمسان في العها العثماني، شكل ا، ص. •1. }
\end{aligned}
$$

(خريطة () مدينة تلمسان(أقادير و تاكرارت)، بتصرف عن Marçais, W., et G., Les Monuments Arabes de Tlemcen,Fig.13.
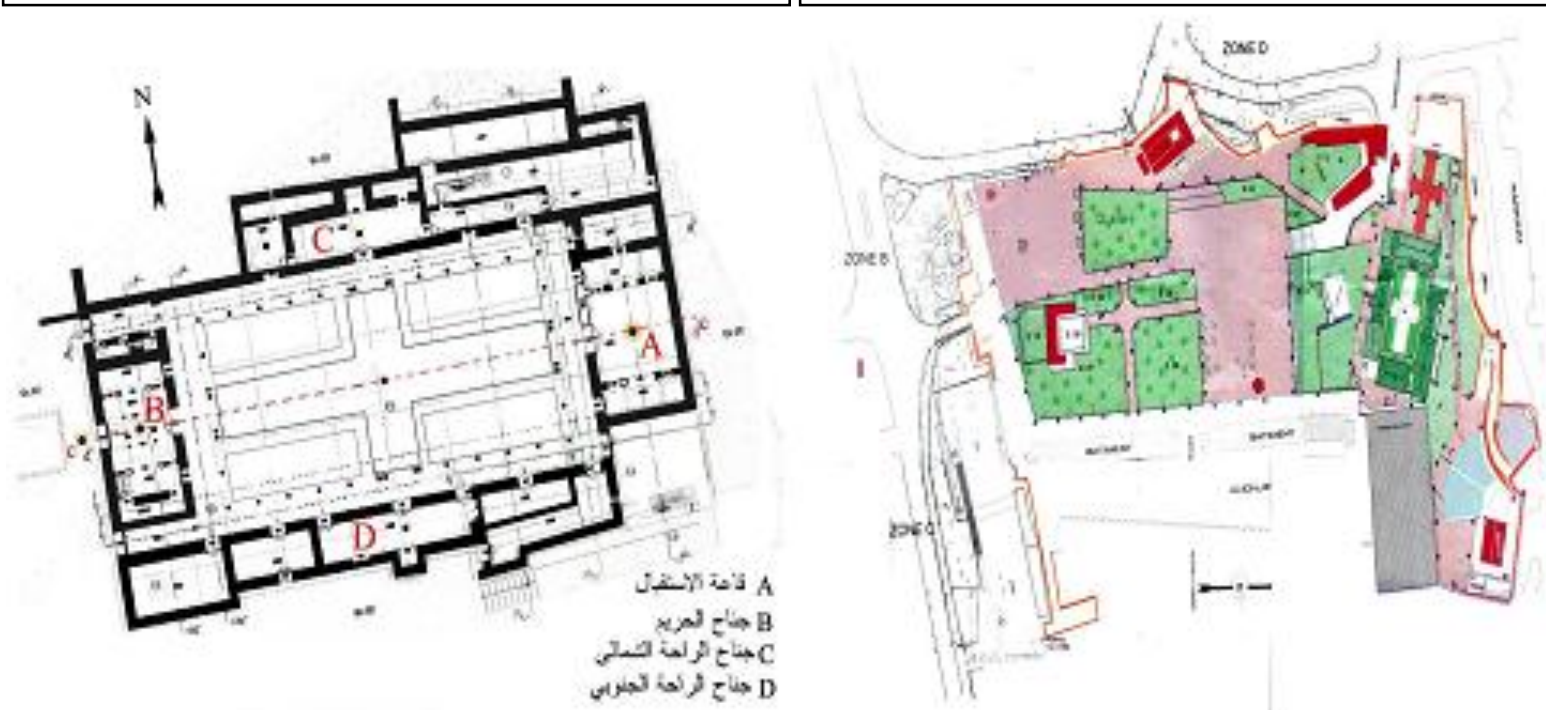

(شكل () مسقط أفقي لقصر المشور الزيانى بنلمسان بتصرف عن: Arcade Tlemcen

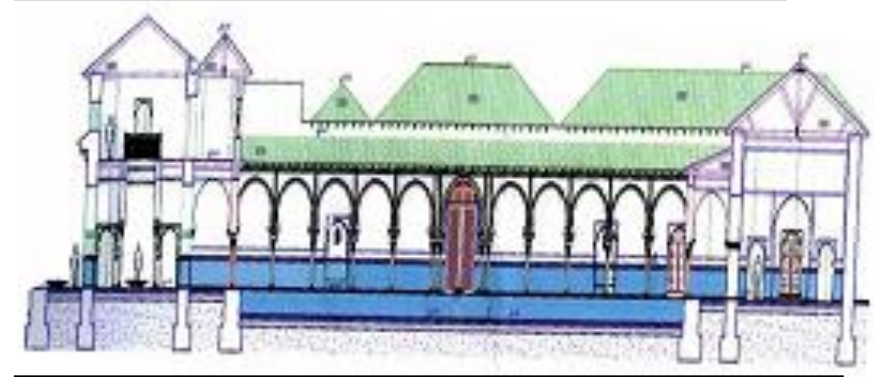

(خريطة r) العمائر الباقية بالمشور الزيانى

عن:Arcade Tlemcen

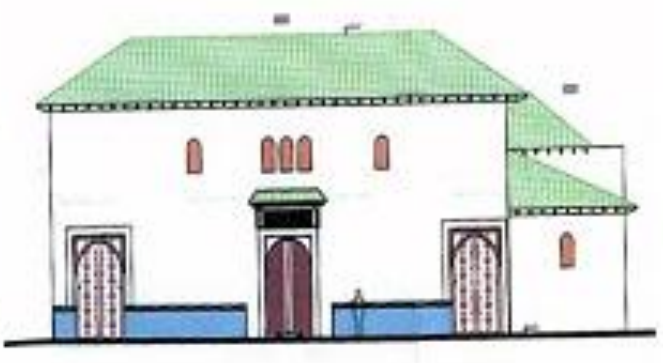

(شكلr) قطاع رأسيCC بقصر المشور الزيانى

(شكلr) الو اجهة الغربية لقصر المشور الزيانى

عن: Arcade Tlemcen

عن: Arcade Tlemcen 


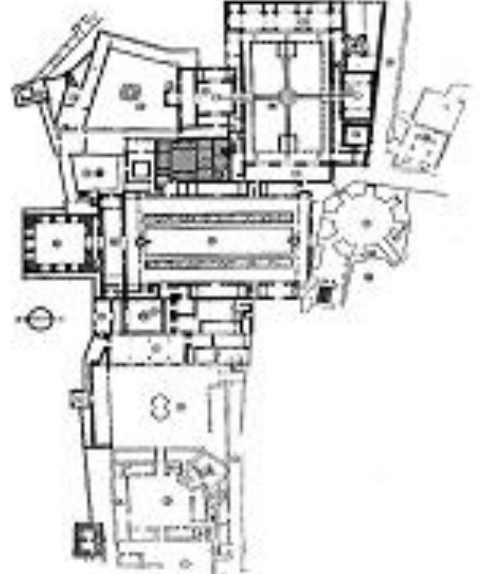

(شكل0) مسقط أفقي لقصر الحمر اء بغرناطة، عن: Marçais, G., L'Architecture Musulmane,p303,

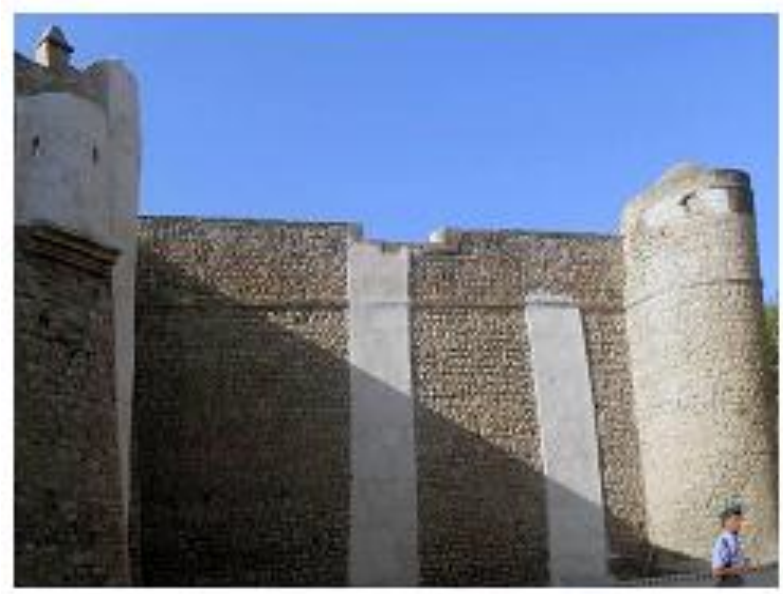

(لوحةr) سور المشور الزيانى من الخارج تصوير الباحث

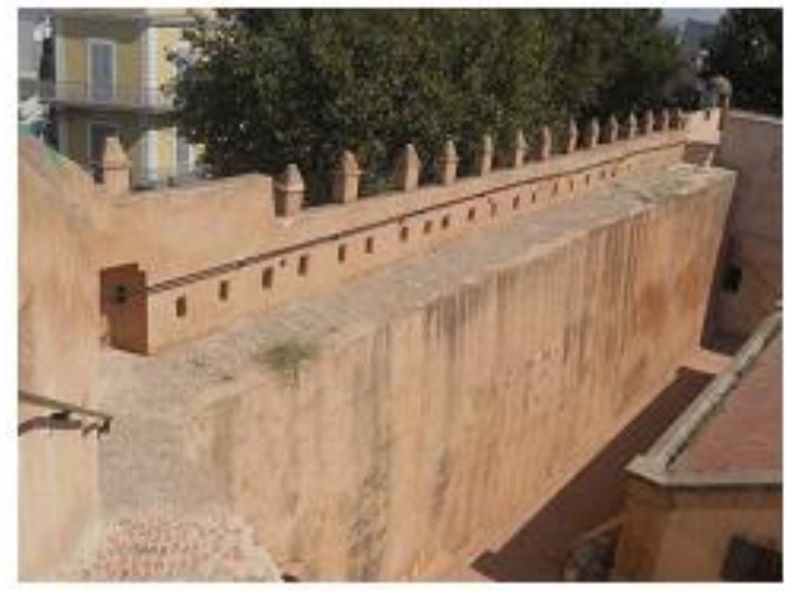

(لوحة؛) سور المشور الزيانى من الداخل تصوير الباحث

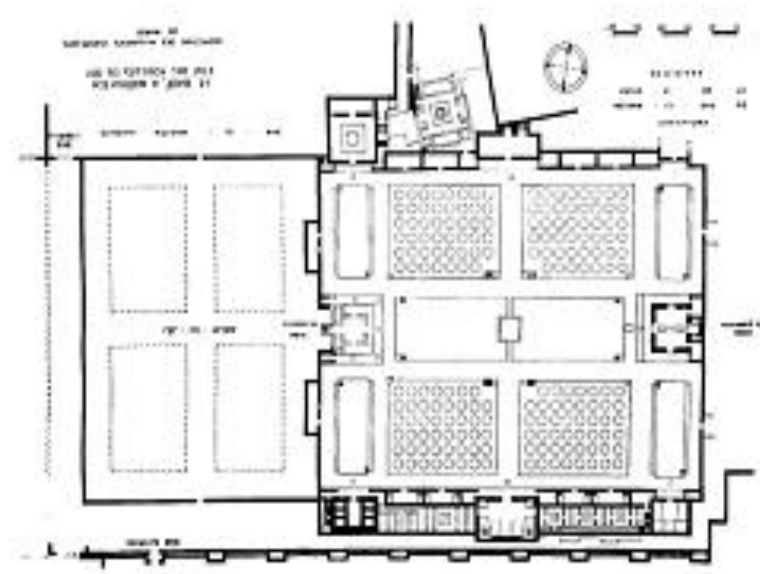

(شكل) ) مسقط أفقي لقصر البديع السعدي بمر اكث عن: مفتنية المباني التاريخية بمر اكث

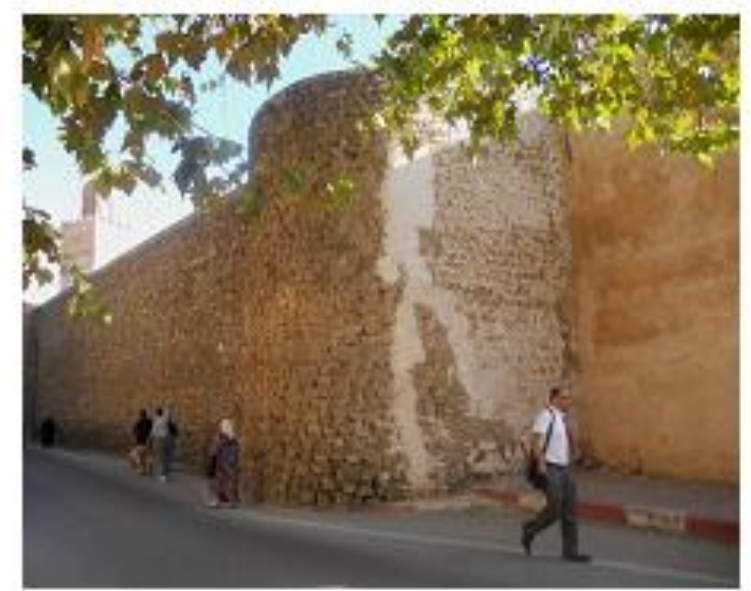

$$
\begin{gathered}
\text { (لوحة) سور المشور الزيانى من الخارج } \\
\text { (لصوير الباحث }
\end{gathered}
$$

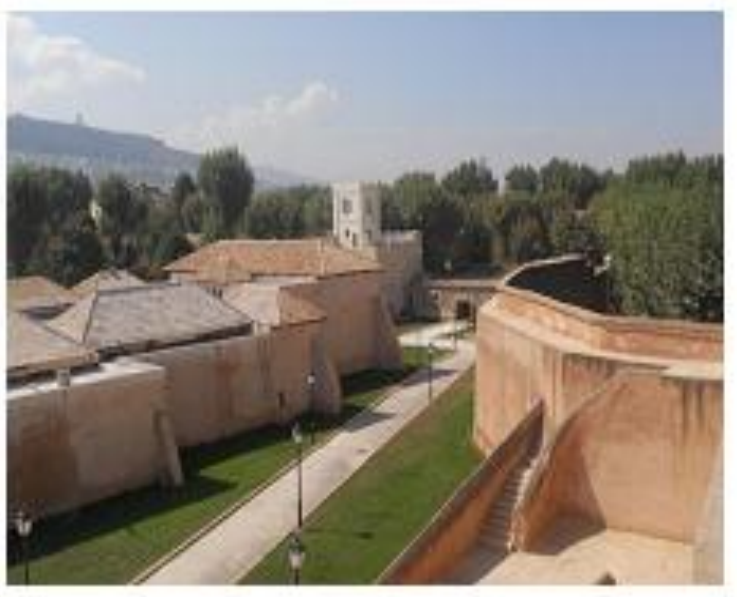

(لوحة") سور المثور من الداخل بالجهة الثمالية المجاورة للقصر تصوير الباحث: 

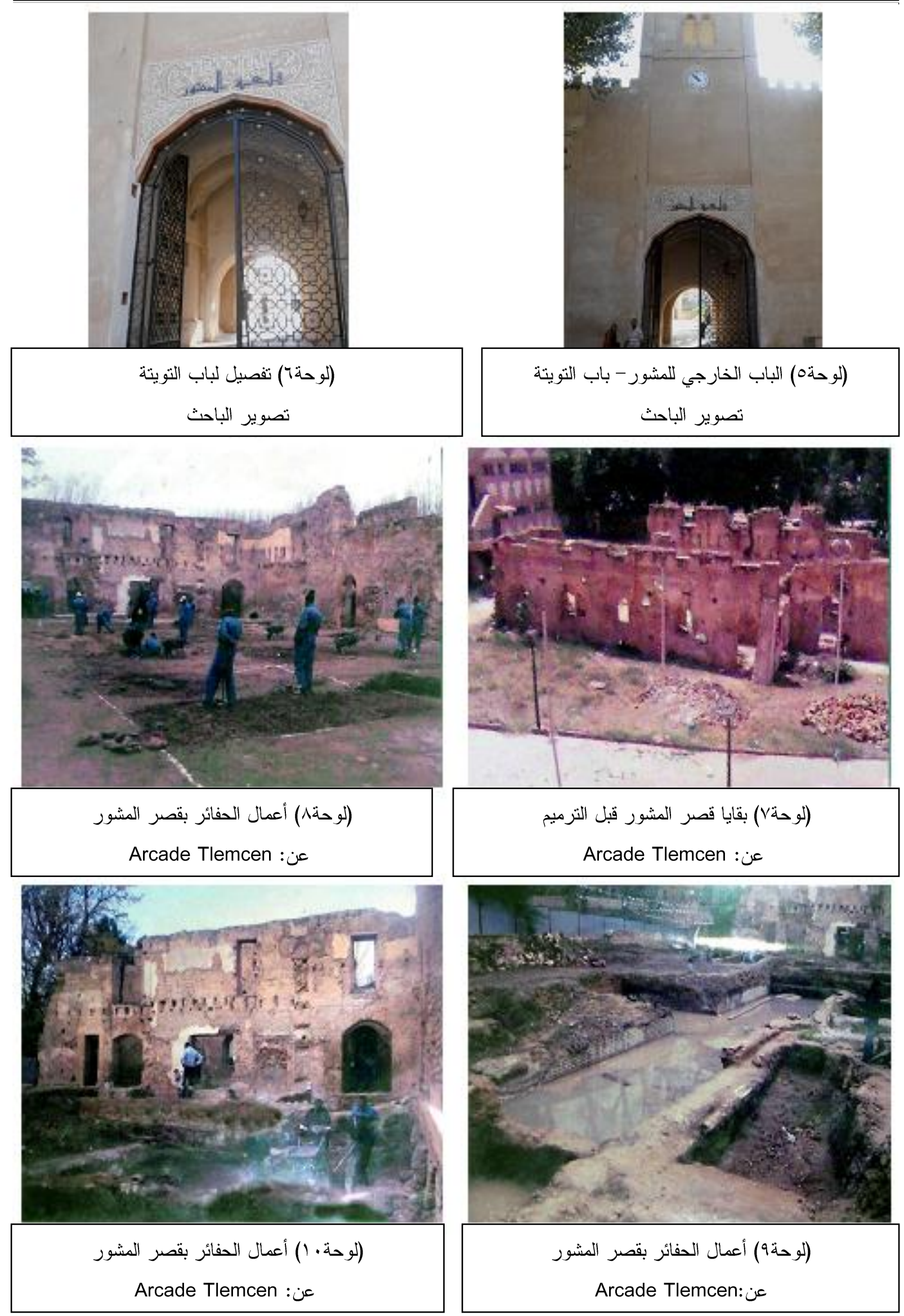

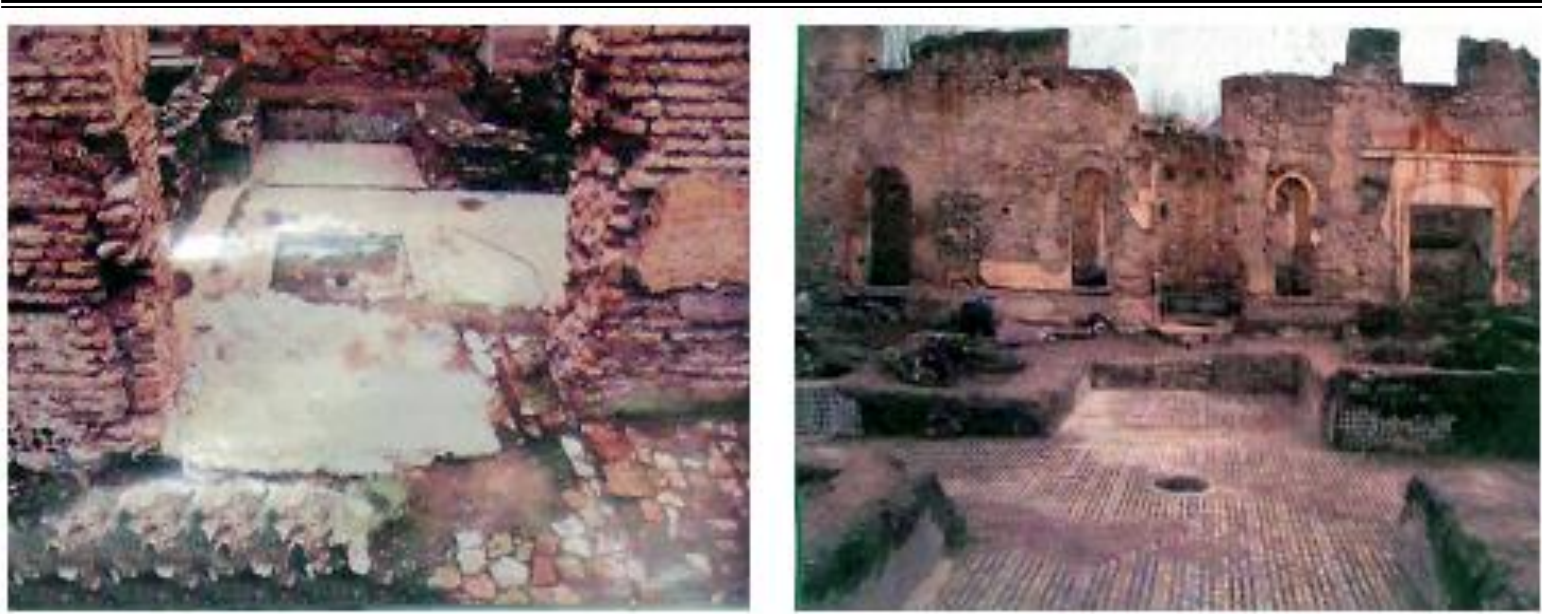

(لوحةr ( ) أعمال الحفائر بقصر المشور عن: Arcade Tlemcen
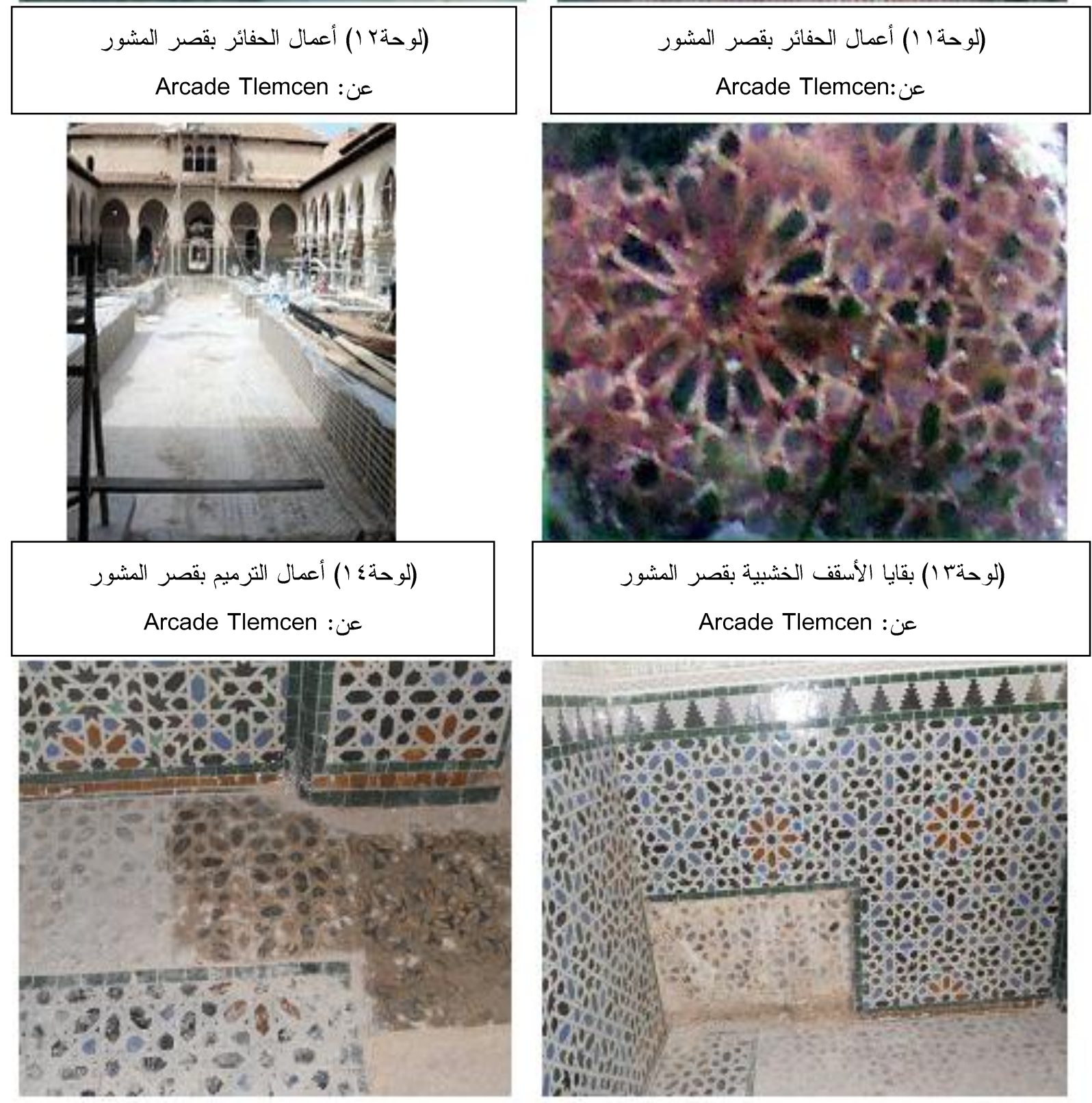

(لوحةج () تحديد بقايا الزليج الأصلية بقصر المشور تصوير الباحث

(لوحةه () تحديد بقايا الزليج الأصلية بقصر المشور تصوير الباحث 


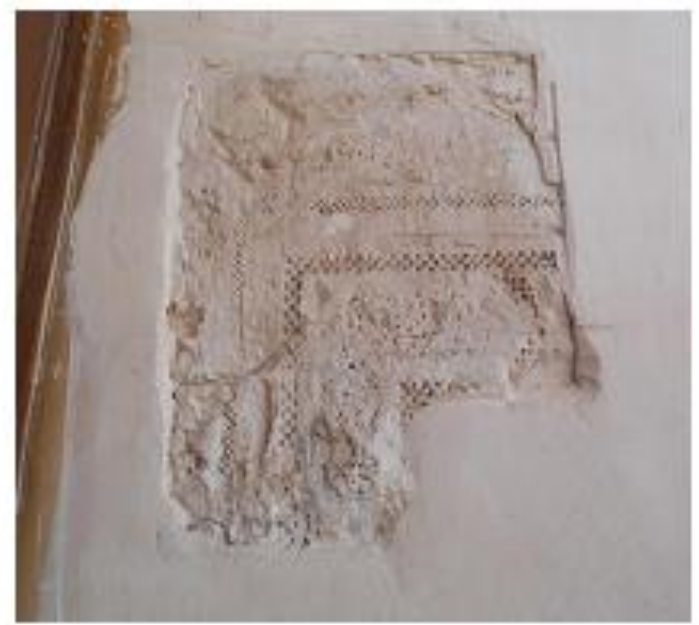

(لوحةه ( ) بقايا التكسيات الجصية بقصر المشور تصوير الباحث

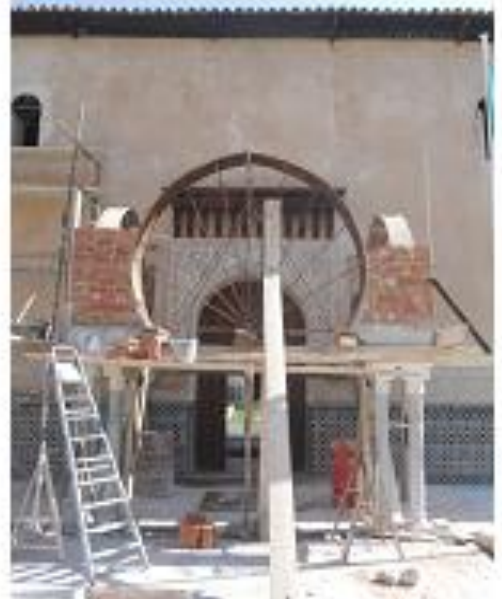

(لوحة. r) المدخل الأوسط بالو اجهة الغربية لقصر المشور تصوير الباحث

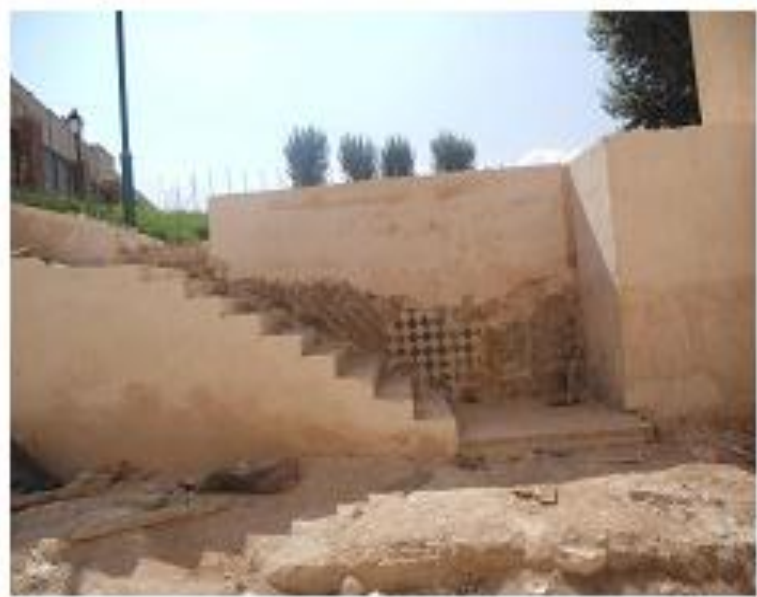

(لوحةr (Y) ملحقات مجاورة للقطاع الجنوبي الثرقي للواجهة الجنوبية لقصر المشور - تصوير الباحث

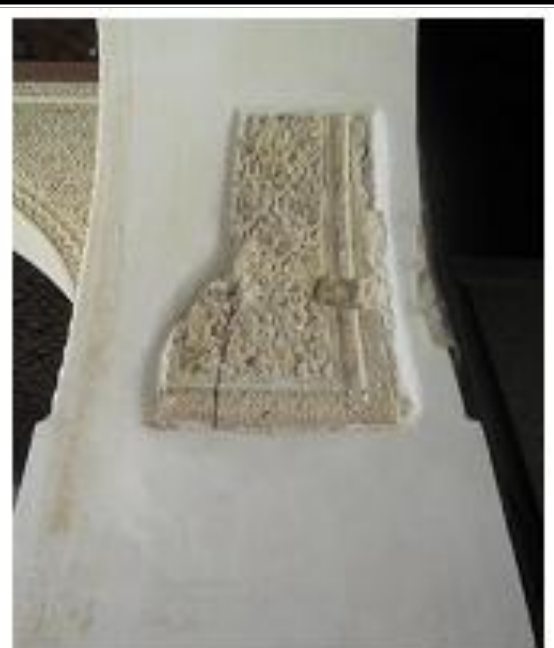

(لوحة V) بقايا التكسيات الجصية بأحد بو اطن العقود بقصر المشور - تصوير الباحث
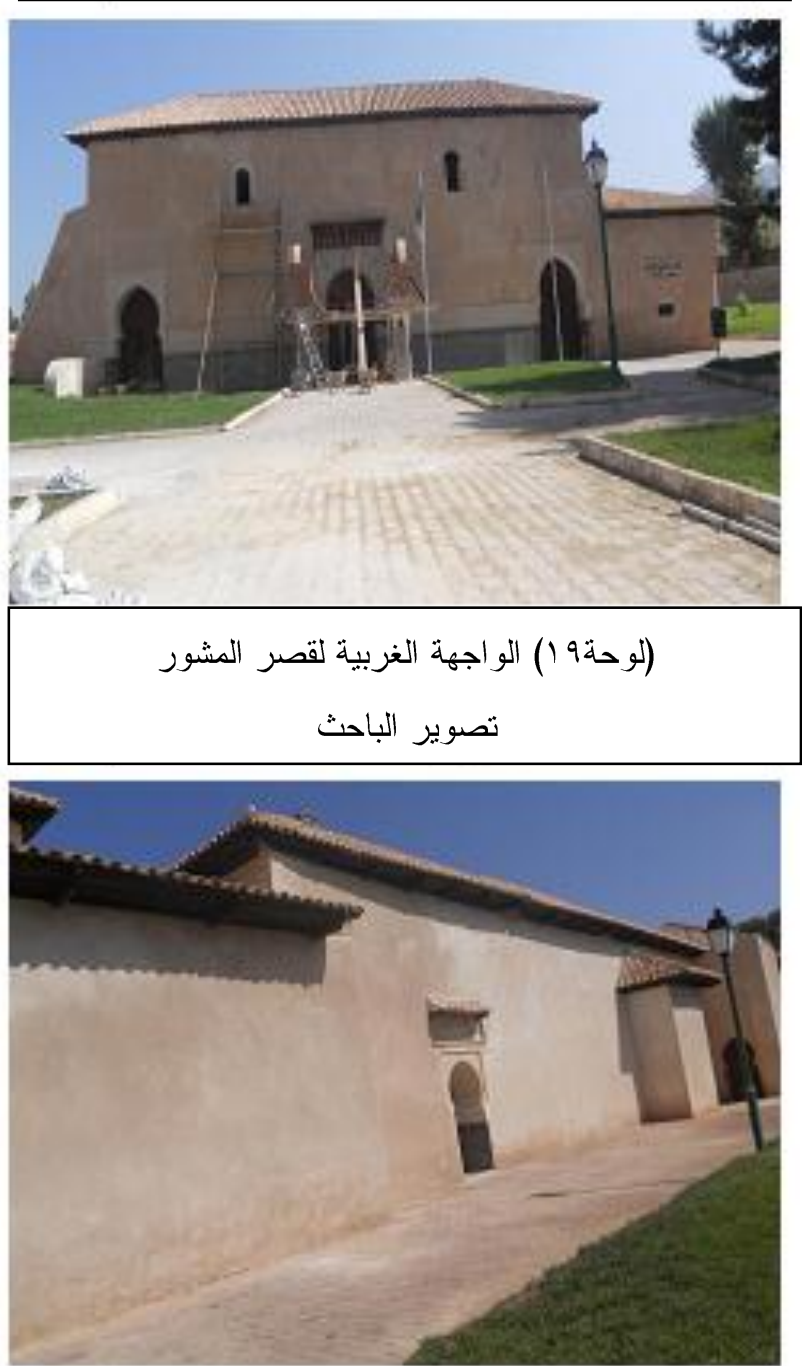

(لوحة الو قطاع من الو اجهة الجنوبية لقصر المشور تصوير الباحث 

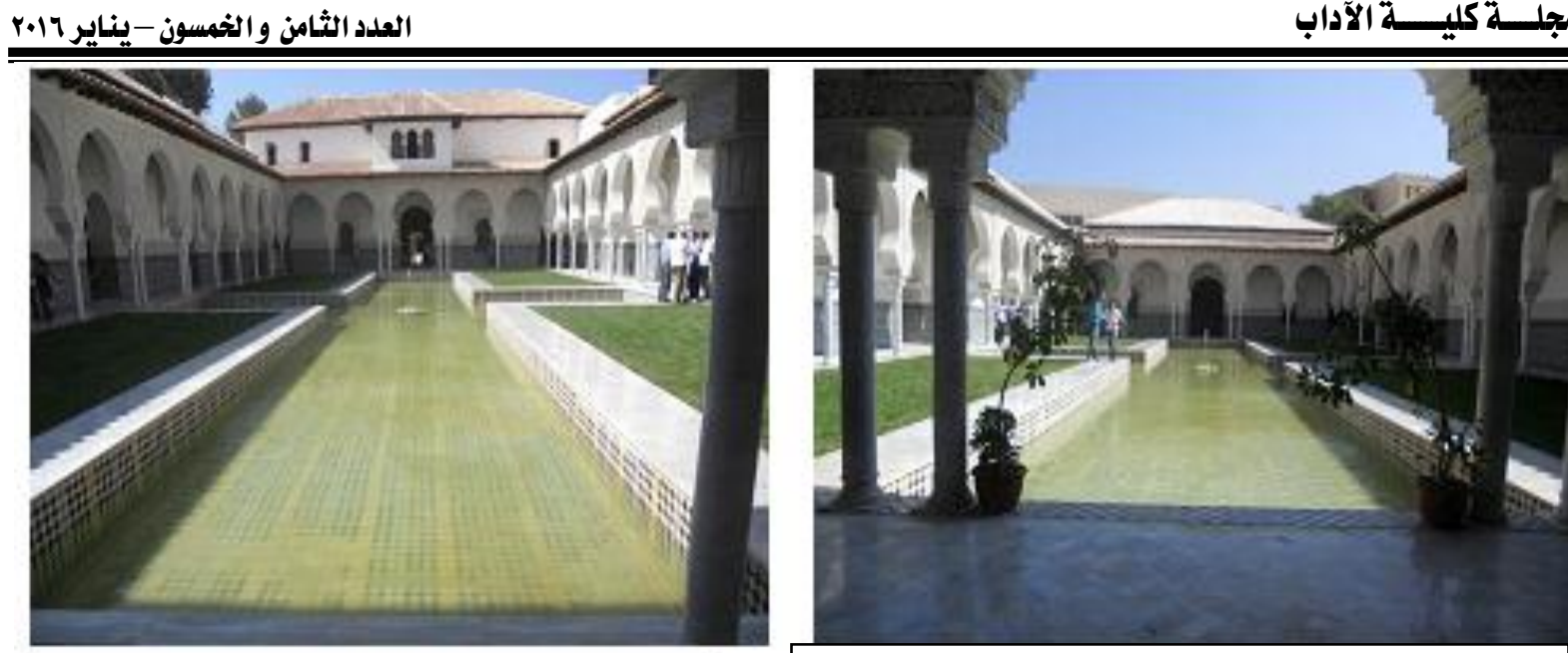

(لوحة؛ r) صحن القصر و الصهريج الذي ينوسطه تصوير الباحث

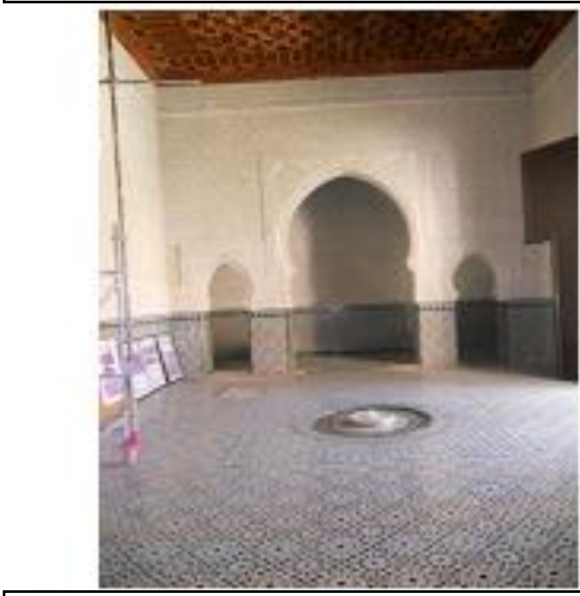

(لوحةrr) الصحن الذي ينوسط قصر المشور تصوير الباحث

(لوحةجr) قاعة الاستقبال من الداخل تصوير الباحث

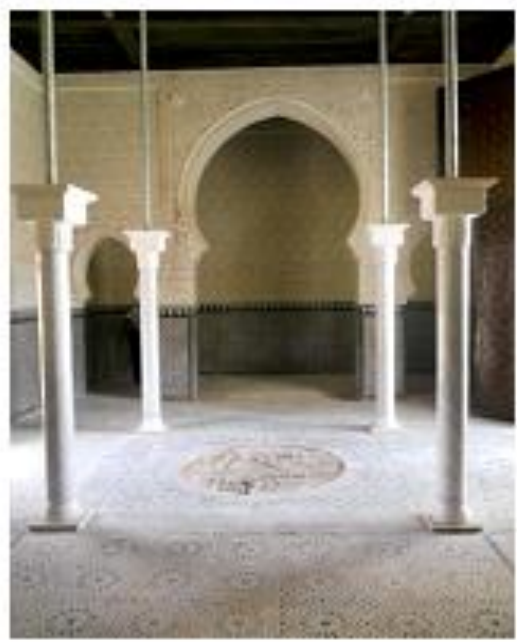

$$
\text { (لوحةم ب) الحجرة الوسطى بجناح الحريم }
$$

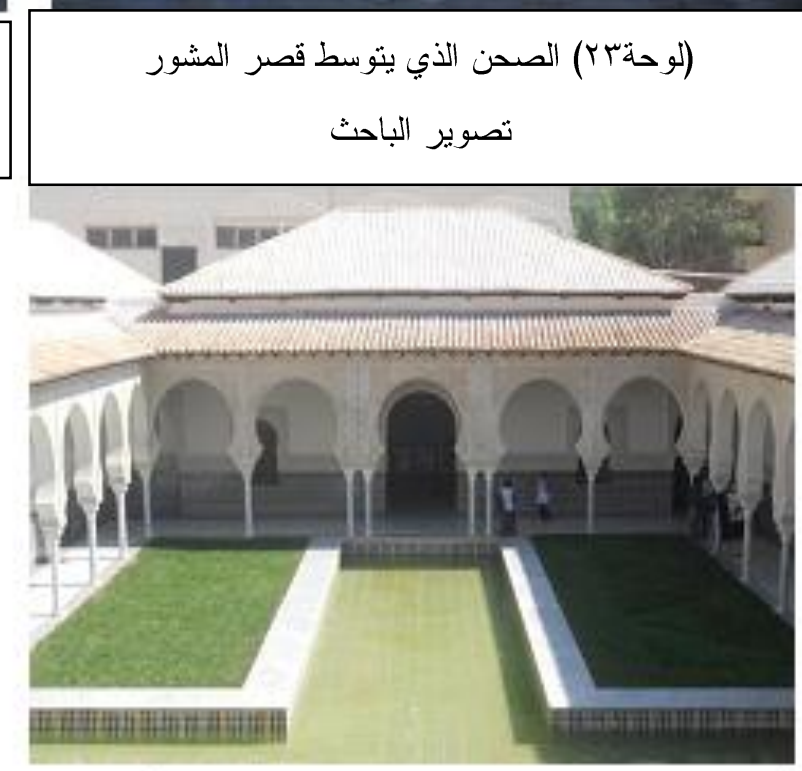

(لوحةه r) الو اجهة الغربية لقاعة الاستقبال تصوير الباحث

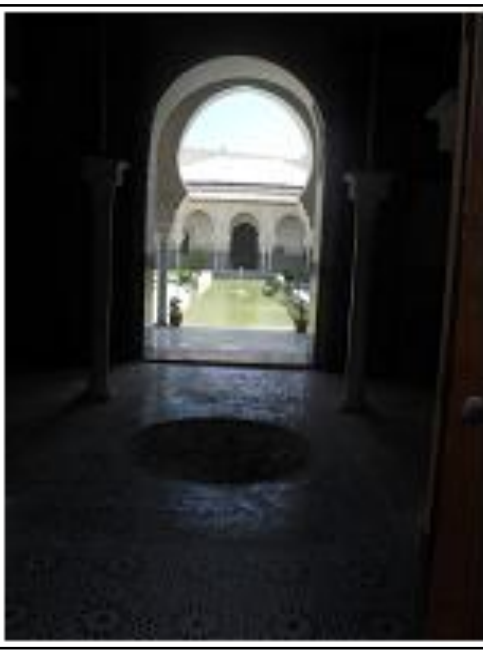

(لوحةVr) جناح الحريم من الداخل تصوير الباحث 


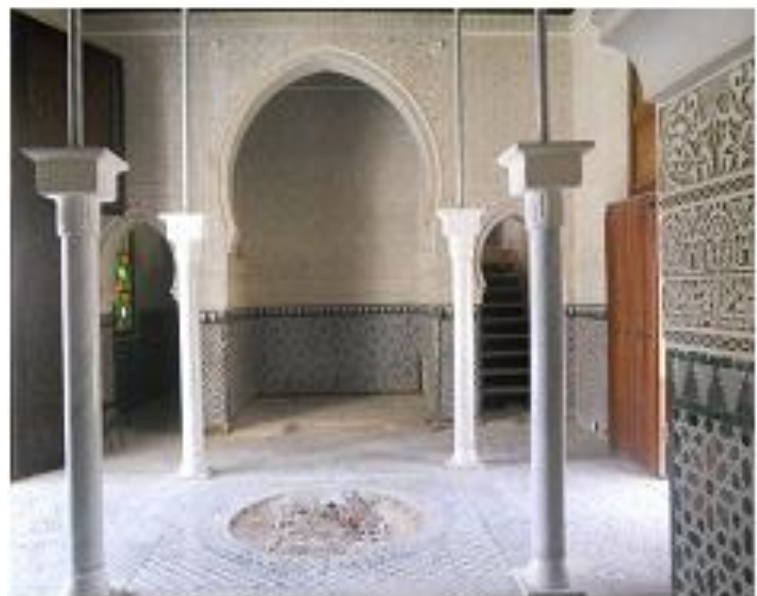

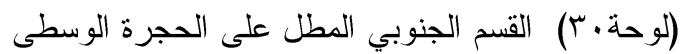
لجناح الحريخ- تصوير الباحث

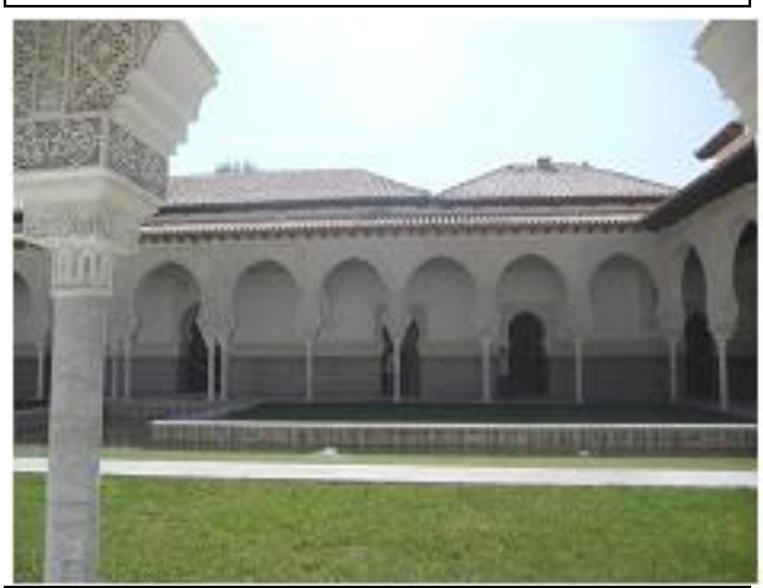

(لوحةrr) الو اجهة الثمالية لجناح الر احة الجنوبي تصوير الباحث

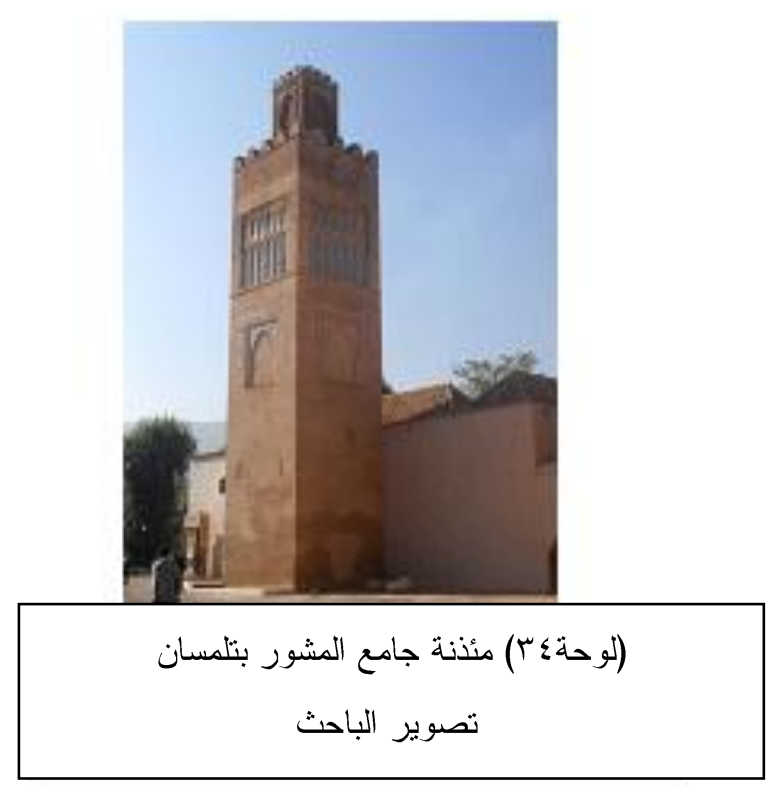

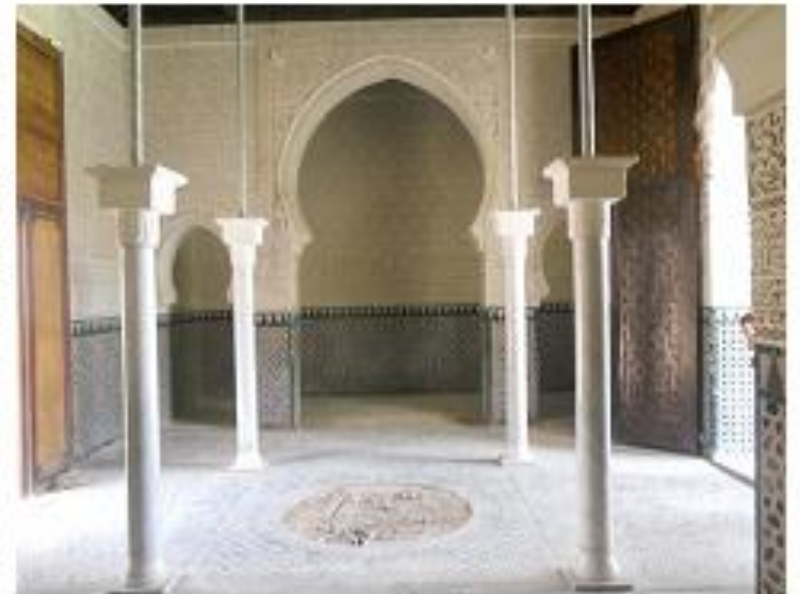

(لوحة9r) القسم الثمالي المطل على الحجرة الوسطى لجناح الحريم- تصوير الباحث
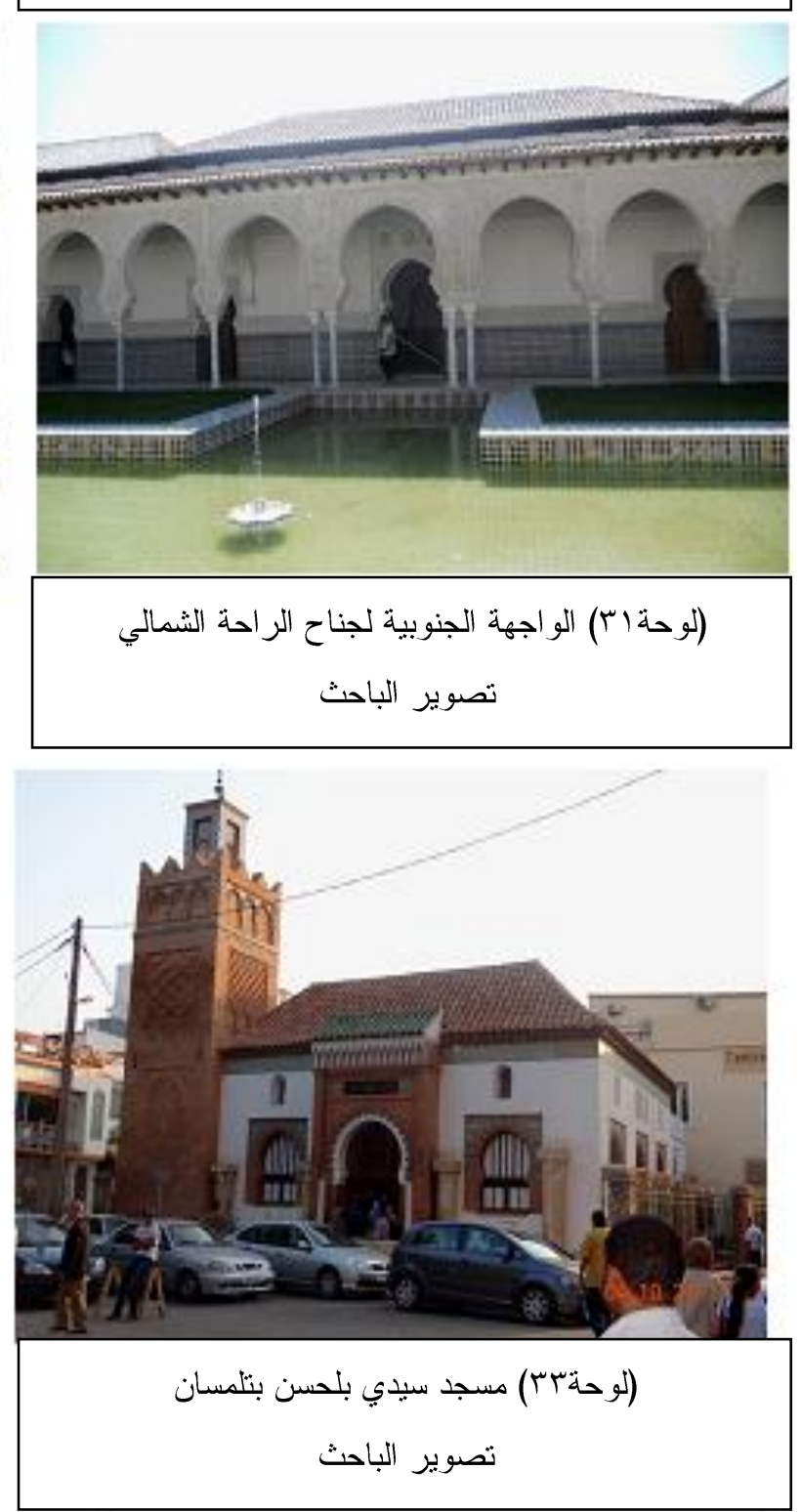